\title{
Nucleic acids complexation with cationic elastin-like polypeptides: stoichiometry and stability of nano-assemblies
}

\author{
L. M. Bravo-Anaya*,1, B. Garbay ${ }^{1}$, J.L.E. Nando-Rodríguez ${ }^{1,2}$, F. Carvajal Ramos $^{2}$, E. \\ Ibarboure $^{1}$, K. Bathany ${ }^{3}$, Y. Xia ${ }^{1}$, J. Rosselgong ${ }^{1}$, G. Joucla ${ }^{3}$, E. Garanger ${ }^{1}$, S. Lecommandoux ${ }^{* 1}$ \\ ${ }^{1}$ Univ. Bordeaux, CNRS, Bordeaux INP, LCPO, UMR 5629, F-33600, Pessac, France. \\ ${ }^{2}$ Centro Universitario UTEG, Departamento de Investigación, Héroes Ferrocarrileros \#1325 C.P. 44460, \\ Guadalajara, Jalisco, México. \\ ${ }^{3}$ Univ. Bordeaux, CNRS, Bordeaux INP, CBMN, UMR 5248, F-33615, Pessac, France.
}

Corresponding authors:

* Dr. Lourdes Monica Bravo-Anaya, Liphy, Université Grenoble Alpes, 140, Rue de la Physique, 38402 Saint-Martin-d'Hères, France. Tel: +33 6568862 06. Email: monik_ayanami@hotmail.com

* Prof. Sébastien Lecommandoux, LCPO, ENSCBP, 16 avenue Pey-Berland, 33607 Pessac Cedex, France.

Tel: +33 540002 241. E-mail: lecommandoux@enscbp.fr

\section{Graphical abstract}

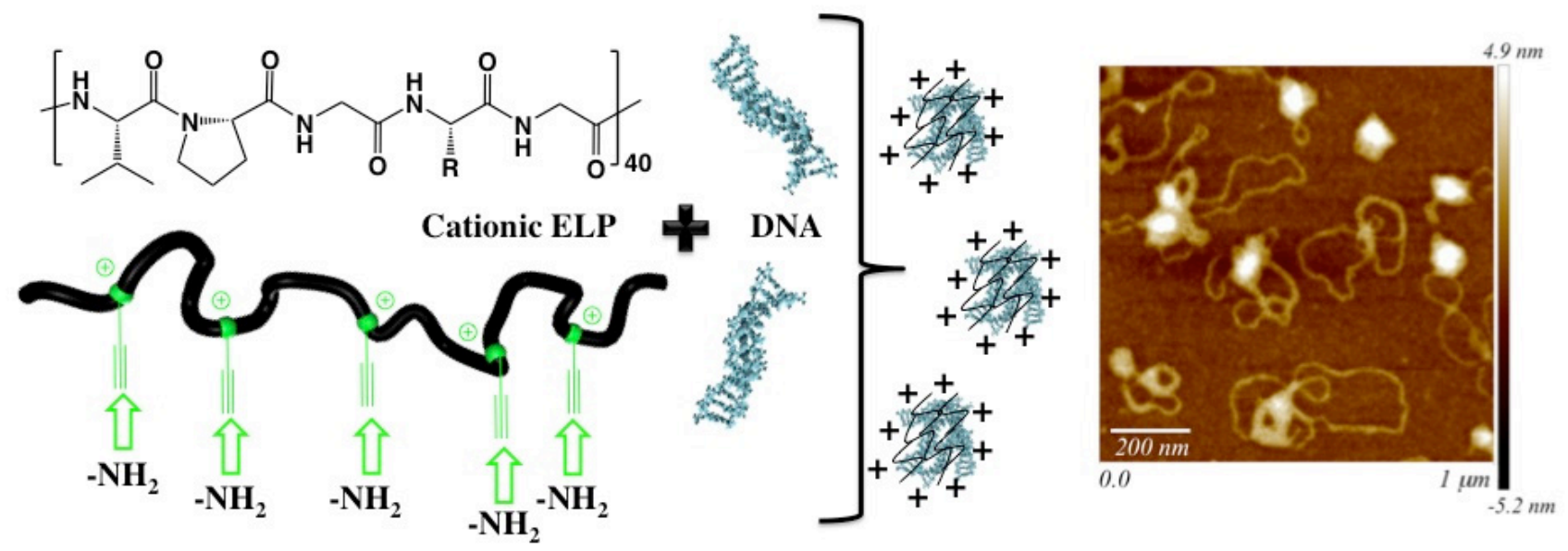




\begin{abstract}
Positively charged elastin-like polypeptides (ELPs) were synthesized for the compaction of genetic material. A recombinant ELP (VPGXG) 40 with $\mathrm{X}=\mathrm{V}, \mathrm{M}(3: 1)$ was post-modified in two steps to introduce chemoselectively either primary or secondary amine pendant groups at each methionine residue. Positively charged ELPs were characterized by SDS-PAGE, size exclusion chromatography, ${ }^{1} \mathrm{H}$ NMR, potentiometric titrations and dynamic light scattering to assess their purity and determine their degree of functionalization, molecular weight, isoelectric point and thermo-responsive behaviour. Electrostatic complexation between the different ELP derivatives and nucleic acids was studied to determine the stoichiometry of $\mathrm{ELP}_{\mathrm{S}} /$ nucleic acids complex formation, and to find optimal conditions leading to stable nanoparticles with controlled size and surface potential. The stability of these complexes was investigated in the presence of salts at physiological concentrations and in the presence of surfactant. This study revealed that two regimes of stable nanoparticles in terms of size and charge can be obtained from the electrostatic complexation between the primary amine containing ELP derivative, ELP(- $\left.\mathrm{NH}_{2}\right)$, and plasmid DNA. Resulting complexes were found to be stable to dissociation for charge ratios up to 2.5 under physiological salt concentrations $(154 \mathrm{mM} \mathrm{NaCl})$, showing that plasmid DNA was completely condensed by the polycationic ELP and protected against electrolyte-mediated dissociation.
\end{abstract}

Keywords: DNA, ELP, chemoselective thioalkylation, polyelectrolyte complexes, electrostatic interactions, stoichiometry, stability. 


\section{Introduction}

The design of biocompatible polymers is currently an intense field of research for the development of non-viral vectors for gene therapy and in vivo delivery of polynucleotides (DNA or RNA) [1-3], as well as for the delivery of different biologically active macromolecules such as proteins [4]. Nucleic acids delivery principle relies on the use of DNA/RNA compacting agents, referred to as vectors or gene carriers, that can compact and protect the genetic material from degradation in biological fluids, and that can deliver it inside the target cells $[5,6]$. These compacting agents can be polycations able to form polyelectrolyte complexes through electrostatic interactions between oppositely charged polyions (DNA and the vectors) [7,8]. Their formation and properties depend on diverse factors including macromolecular parameters such as molecular weight of the polyelectrolytes, chemical nature of the ionic groups and charge density, as well as formulation parameters such as concentration, relative proportion of opposite charges, and physico-chemical environment (i.e., complexation medium, presence of cosolutes, addition of salts, among others) [8-13]. In nature, polyelectrolyte complexes have important functions where charged systems, such as cell membranes, proteins, nucleic acids and polysaccharides interact in body fluids or cellular compartments [14-16]. Over the last few years, inter-polymer interactions phenomena and polyelectrolyte complexes formation have been the attention of rigorous fundamental and applied research such as gene delivery [17].

Few natural polycations possess the characteristics required for gene therapy, such as low immunogenicity, biocompatibility and minimal cytotoxicity $[1,18]$. Despite the fact that great progress has been made in vectors development, such as cationic polymers (polyethylenimine, chitosan) [19,20], cationic liposomes (DOTAP) [21], peptides (CPP) [22], many challenges still need to be overcome to improve the controlled release properties and efficacy of these delivery systems [23]. Among numerous cationic polymers, polyethylenimine (PEI) is one of the most potent non-viral polymeric gene vectors due to its $\mathrm{pH}$ buffering capacity. The significant capacity of PEI to deliver nucleic acids was mainly attributed to a "proton sponge" effect, in which the previously mentioned buffering capacity of PEI attends two purposes, i.e. to inhibit the activity of lysosomal nuclease, and to change the acidic vesicles osmolarity, which results in endosomal swelling and rupture [24]. However, its toxic side effects and non-degradable nature 
prevent its use in vivo as well as any clinical development [25]. Therefore, the design of novel and potent polymeric vectors still represents an important challenge.

Elastin-like polypeptides (ELPs) are biopolymers composed of repeating pentapeptide sequences Val-Pro-Gly-Xaa-Gly, (VPGXG), where the guest residue $(X a a, X)$ can be any amino acid except proline [26-28]. ELPs are actually of great interest for specific biomedical and biotechnological applications mainly due to their stimuli-responsive self-assembly properties [26,29]. These biopolymers indeed undergo a reversible phase transition, which can be triggered by different environmental stimuli, such as ionic strength, temperature and $\mathrm{pH}$ [28,30,31]. ELPs are soluble in aqueous media below a characteristic transition temperature $\left(\mathrm{T}_{\mathrm{t}}\right)$, also referred to as lower critical solution temperature (LCST). As the temperature increases, polypeptide chains desolvate and aggregate leading to phase separation [26]. The nature of the guest residues in the successive ELP repeat units, the chain length and molecular weight, the type and concentration of cosolutes and the concentration of ELP influence the phase transition [26-28,32]. When designed from ELP segments with different $T_{t}, E L P s$ can self-assemble into micellar systems and thus have been explored as nanocarriers for drug delivery [33-35]. ELPs are therefore very attractive biomimetic polypeptides because of their exquisite features such as precise sequence, monodispersity, biocompatibility and stimuliresponsive properties [26,36,37]. In addition, it has been demonstrated that ELPs do not present any intrinsic cytotoxicity [38]. ELPs are also composed of natural amino acids that can be degraded into non-toxic metabolites, in contrast with certain synthetic polymers [39].

Similarly to natural or recombinant proteins, ELPs can also be chemically modified onto reactive amino acid residues to introduce additional functionality and/or bioactivity using classical bioconjugation methods [41,41]. ELPs have for instance been conjugated to low molecular weight organic molecules [36], drugs [40,42,43], and oligonucleotides [44]. Applying the general methodology developed by Deming et al. to introduce a wide range of functional groups onto polypeptides by chemoselective alkylation of methionine residues using epoxides [45], our group demonstrated the possibility to easily tune their $T_{t}$ and introduce diverse functional groups by chemoselectively post-modifying recombinant ELPs containing periodically spaced methionine residues [46]. 
ELPs are attractive materials for biomedical applications such as gene and drug delivery $[41,47]$. More specifically, cationic ELPs for DNA condensation were firstly designed from the genetic fusion of an ELP and a positively charged domain consisting of an eight-residue oligolysine peptide, $\mathrm{K}_{8}$-ELP(1-60). Efficient plasmid DNA (GFP) transfection was demonstrated with a lower toxicity than polyethylenimine [41]. Intelligent biosynthetic nanobiomaterials, presenting both cationic and thermo-sensitive behaviors, were designed and explored for multimodal gene delivery, drug delivery, and therapeutic fusion proteins by using similar diblock copolymers [48]. Recently, Lee et al. explored the application of ELPs for reprogramming mouse fibroblasts into induced pluripotent stem cells (iPSCs). For this, they engineered an ELP with positively charged lysine residues for complexation with cDNAs and they revealed that after transfection, the iPSCs showed embryonic stem cell-like characteristics [49]. Another approach to deliver multiple therapeutic genes was developed through an injectable system comprising hollow spheres and an in situ-forming gel scaffold of elastin-like polypeptide capable of carrying gene complexes system [50,51]. Kim et al. were also interested in the development of an ELP-mediated adeno-associated virus (AAV) delivery system for transducing fibroblasts and human neural stem cells (hNSCs), seeking for relevant gene therapy systems for stem cell research and tissue regenerative medicine [52]. Positively charged ELPs were synthetized by Lim et al. by incorporating periodic Lys residues to provide sites for chemical cross-linking. However, the incorporation of Lys residues raised the $T_{\mathrm{t}}$ at physiological pH, making purification of these ELPs by Inverse Transition Cycling (ITC) difficult within a reasonable temperature range $[53,54$,$] .$

Because genetic engineering of recombinant ELPs with various designs and sequences imply long and tedious molecular cloning steps, our group explores a more versatile dual biotechnological/synthetic approach. ELP scaffolds are first produced recombinantly in Escherichia coli (E. coli) bacterial hosts and subsequently chemoselectively modified to introduce various functionalities. In particular, ELPs containing periodically spaced methionine residues have been engineered and chemoselectively modified at the thioether side chain of each methionine residues $[26,46,55]$. We believed this approach to be particularly relevant for the generation of positively charged ELPs that can be difficult to produce and purify by Inverse Transition Cycling [56,57] in high yields due to high transition temperatures. Thioether alkylation reaction providing sulfonium groups (positively charged) [45] was preferred among 
other chemical modifications [58] to introduce $\mathrm{pH}$ responsive amine groups onto the ELP scaffold for DNA compaction. In this work, a forty repeat ELP sequence containing a total of 11 methionine residues was thioalkyted to position alkyne handles for subsequent introduction of two distinct amine groups (primary and secondary amines) by Huisgen cycloaddition. The three ELP derivatives bearing either an alkyne, a primary amine or a secondary amine group grafted onto methionine residues' side chain, thereafter noted ELP(-CCH), ELP(- $\left.\mathrm{NH}_{2}\right)$ and ELP($\mathrm{NHCH}_{3}$ ) respectively (Scheme 1), were characterized by several analytical techniques such as SDS-PAGE, Size Exclusion Chromatography (SEC), ${ }^{1} \mathrm{H}$ NMR, potentiometric titrations and Dynamic Light Scattering (DLS) to assess their purity, and to determine their degree of functionalization, molecular weight, isoelectric point and thermo-responsive behaviour. The interaction of these polycationic $\mathrm{pH}$ responsive ELPs with two types of DNA, a genomic one (calf-thymus DNA) and a small double-stranded molecule (pUC19 plasmid), was studied. After compaction of these nucleic acids with the different ELP derivatives, we determined the stoichiometry of $\mathrm{ELP}_{\mathrm{S}} /$ nucleic acids complex formation and the nature of interactions to find optimal conditions yielding stable nanoparticles with controlled size and surface potential at different charge ratios.

\section{Materials and methods}

\subsection{Materials}

We used calf thymus DNA, from Sigma-Aldrich (FR), with an average molecular weight of 6,559,500 g/mol [59]. The pUC19 plasmid (2,985 bp) was purified from an E. coli culture with the Midiprep Macherey Nagel kit according to the manufacturer's instructions. The purified plasmid pUC19 was dissolved in deionized sterile water, and its purity and concentration were determined by UV spectrophotometry. $\mathrm{NaOH}$ in pellets with impurities $\leq 0.001 \%$, anhydrous $\mathrm{NaCl}$ (99 \%), LB medium, glycidyl propargyl ether ( $\geq 90 \%$ ), glacial acetic acid ( $\geq 99.85 \%$ ), hexafluoroisopropanol (HFIP, $\geq 99 \%$ ), $N, N, N^{\prime}, N^{\prime \prime}, N^{\prime \prime}$-pentamethyldiethylenetriamine (PMDTA, $99 \%$ ), sodium azide (99\%), potassium hydroxide ( $\geq 90 \%$ ), magnesium sulfate ( $\geq 99.99 \%$ ), 2 chloroethylamine hydrochloride (99\%), Ethylenediaminetetraacetic acid (EDTA, $\geq 99.85 \%$ ) and diethyl ether $(\geq 99.0 \%)$ were purchased from Sigma-Aldrich (FR). (2- 
chloroethyl)methylamine hydrochloride was purchased from ChemBridge Corporation (CA, USA). $\mathrm{HCl} 0.1 \mathrm{~N}$ (Titrisol) was supplied by Merck Millipore (FR). Bacto-tryptone and yeast extract were purchased from Biokar Diagnostics (FR). Ampicillin was obtained from Eurobio (FR). Glycerol and isopropyl $\beta$-D-thiogalactopyranoside (IPTG) were purchased from Euromedex (FR). Complete mini EDTA-free protease inhibitors were supplied by Roche Diagnostics (DE). Deionized (DI) water (18 M $\Omega-\mathrm{cm})$ was obtained by passing in-house deionized water through a Millipore Milli-Q Biocel A10 purification unit. Cuprisorb was purchased from Seachem (FR). Acetonitrile (99.9 \%, ACN) was obtained from VWR international (FR). $\mathrm{NaCl}(99.0 \%)$ was purchased from Alfa Aesar (FR). Ammonium acetate and sodium ascorbate were purchased from Fisher Scientific (FR).

Bioproduction, isolation and purification of the recombinant ELP with the primary sequence MW[VPGVGVPGMG(VPGVG) $\left.{ }_{2}\right]_{10}$ was achieved following previously reported procedures $[55]$.

\subsection{Synthetic procedures}

\subsubsection{Synthesis of ELP(-CCH)}

Introduction of an alkyne handle at the side chain thioether group of each methionine residue was achieved as previously described [55]. Briefly, $50 \mathrm{mg}$ of ELP was dissolved in $2.5 \mathrm{~mL}$ of an acetic acid $(\mathrm{AcOH}) / \mathrm{HFIP}$ mixture $(9: 1, \mathrm{v} / \mathrm{v})(20 \mathrm{mg} / \mathrm{mL})$. The solution was degassed by nitrogen bubbling for $1 \mathrm{hr}$. Glycidyl propargyl ether was added to the mixture (10 equiv. per methionine residue), which was subsequently stirred for $48 \mathrm{hr}$ under $\mathrm{N}_{2}$ at room temperature. The reaction mixture was transferred into a 3,000 MWCO ultracentrifugal filter tube and washed with $40 \mathrm{~mL}$ DI water. The final product was lyophilized to obtain an ELP(-CCH) as a white solid.

Details of $\boldsymbol{E L P}(-\boldsymbol{C C H}):{ }^{1} \mathrm{H}$ NMR $\left(400 \mathrm{MHz}, \mathrm{D}_{2} \mathrm{O}, 25^{\circ} \mathrm{C}\right)$ : (main peaks) $\delta 4.5-4.4(\mathrm{~m}, 80 \mathrm{H}$, $\alpha \mathrm{C} H \underline{\mathrm{VPGXG}}$ and $\alpha \mathrm{CH}$ V $\underline{\mathrm{PGXG}}), 4.3$ (s, $\left.22 \mathrm{H}, \underline{\mathrm{OCH}}_{2} \mathrm{CCH}\right), 4.2-4.15$ (d, 30 H, $\alpha \mathrm{CH}$ VPG $\left.\underline{\mathrm{VG}}\right)$,

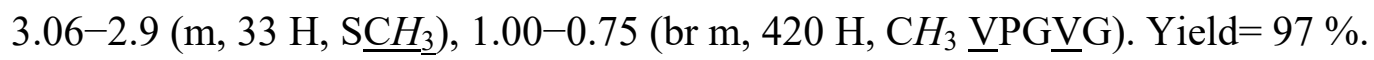




\subsubsection{Synthesis of $\operatorname{ELP}\left(-\mathrm{NH}_{2}\right)$ and $\operatorname{ELP}\left(-\mathrm{NHCH}_{3}\right)$}

2-aminoethylazide and (2-azidoethyl)methylamine were synthesized according to previously reported procedures by nucleophilic substitution of chlorine using sodium azide [60].

Synthesis of 2-aminoethylazide: 2-chloroethylamine hydrochloride (10 g, $86.2 \mathrm{mmol}, 1$ equiv.) was solubilized in DI water $(75 \mathrm{~mL})$, then sodium azide (16.8 g, $258.6 \mathrm{mmol}, 3$ equiv.) was added and the solution was allowed to stir at $80{ }^{\circ} \mathrm{C}$ with a condenser overnight. The mixture was then brought back to room temperature and then cooled to $0{ }^{\circ} \mathrm{C}$ using an ice bath before the addition of $10 \mathrm{~g}$ potassium hydroxide. The solution was allowed to stir for 2 hours while warming back to room temperature. 2-aminoethylazide was extracted from the aqueous phase using diethyl ether ( 3 times with $40 \mathrm{~mL}$ ). The organic phase was then dried on magnesium sulfate, filtered and evaporated under vacuum to lead $1.25 \mathrm{~g}(14.5 \mathrm{mmol}$, yield $=17 \%)$ of slightly yellow oil.

Synthesis of (2-azidoethyl)methylamine: (2-chloroethyl)methylamine hydrochloride (5 g, 38.5 mmol, 1 equiv.) was solubilized in DI water $(40 \mathrm{~mL})$, then sodium azide $(7.51 \mathrm{~g}, 115.5 \mathrm{mmol}, 3$ equiv.) was added and the solution was allowed to stir at $80^{\circ} \mathrm{C}$ with a condenser overnight. The mixture was then brought back to room temperature and then cooled to $0{ }^{\circ} \mathrm{C}$ using an ice bath before the addition of $5 \mathrm{~g}$ potassium hydroxide. The solution was allowed to stir for 2 hours while warming back to room temperature. (2-azidoethyl)methylamine was extracted from the aqueous phase using diethyl ether (4 times with $30 \mathrm{~mL}$ ). The organic phase was then dried on magnesium sulfate, filtered and evaporated under vacuum to lead $0.73 \mathrm{~g}(7.3 \mathrm{mmol}$, yield $=19$ $\%)$ of slightly yellow oil.

The ELP(-CCH) derivative was dissolved in DI water $(5 \mathrm{~g} / \mathrm{L})$ and 2-aminoethylazide (slightly yellow oil, 1.5 equiv. per alkyne) or (2-azidoethyl)methylamine (slightly yellow oil, 1.5 equiv. per alkyne) was added. The solution was degassed by bubbling $\mathrm{N}_{2}$ for 2 hours and then stirred under $\mathrm{N}_{2}$. Separately, a solution of $\mathrm{Cu}(\mathrm{I})$ was prepared by addition of sodium ascorbate $(0.65$ equiv. per alkyne) to a degassed solution of $\mathrm{Cu}(\mathrm{II}) \mathrm{SO}_{4}$ (0.13 equiv. per alkyne) and PMDTA ( 0.13 equiv. per alkyne) in $2.5 \mathrm{~mL}$ of water. The $\mathrm{Cu}(\mathrm{I})$ solution was transferred to the reaction mixture with a syringe. The reaction was stirred under $\mathrm{N}_{2}$ at room temperature for 72 hours, transferred to a 3,000 MWCO ultra-centrifugal filter tube and washed first with an aqueous 
solution of EDTA $(0.15 \mathrm{M})$ and then with $40 \mathrm{~mL}$ DI water. The purified reaction mixture was then lyophilized to provide $\operatorname{ELP}\left(-\mathrm{NH}_{2}\right)$ or $\operatorname{ELP}\left(-\mathrm{NHCH}_{3}\right)$, respectively, as a white solid.

Details of $\boldsymbol{E L P}\left(-\mathrm{NH}_{2}\right):$ ELP(-NH$)$ was prepared from ELP(-CCH) and 2-aminoethylazide $\left(\mathrm{N}_{3}-\right.$ $\left.\mathrm{CH}_{2}-\mathrm{CH}_{2}-\mathrm{NH}_{2}\right)$. Yield $=95 \% ;{ }^{1} \mathrm{H}$ NMR $\left(400 \mathrm{MHz}, \mathrm{D}_{2} \mathrm{O}, 25{ }^{\circ} \mathrm{C}\right)$ : (main peaks) $\delta 8.4-8.3$ (br s, $11 \mathrm{H}$, triazole- $H), 4.5-4.4(\mathrm{~m}, 80 \mathrm{H}, \alpha \mathrm{C} H \underline{\mathrm{VPGXG}}$ and $\alpha \mathrm{CH}$ VPGXG), 4.2-4.15 (d, $30 \mathrm{H}, \alpha \mathrm{CH}$ VPGㅁG), 1.00-0.75 (br m, $420 \mathrm{H}, \mathrm{CH}_{3} \underline{\mathrm{VPG}} \underline{\mathrm{VG}}$ ).

Details of $\boldsymbol{E L P}\left(-\mathrm{NHCH}_{3}\right): \quad \mathrm{ELP}\left(-\mathrm{NHCH}_{3}\right)$ was prepared from ELP(-CCH) and (2azidoethyl)methylamine $\left(\mathrm{N}_{3}-\mathrm{CH}_{2}-\mathrm{CH}_{2}-\mathrm{NH}-\mathrm{CH}_{3}\right)$. Yield $=95 \% ;{ }^{1} \mathrm{H}$ NMR $\left(400 \mathrm{MHz}, \mathrm{D}_{2} \mathrm{O}, 25\right.$ $\left.{ }^{\circ} \mathrm{C}\right)$ : (main peaks) $\delta$ 8.4-8.3 (br s, $11 \mathrm{H}$, triazole- $H$ ), 4.5-4.4 (m, 80 H, $\alpha \mathrm{CH} \underline{\mathrm{VPGXG}}$ and $\alpha \mathrm{CH}$ V $\underline{P G X G), ~ 4.2-4.15 ~(d, ~} 30 \mathrm{H}, \alpha \mathrm{CH}$ VPGG), 1.00-0.75 (br m, $\left.420 \mathrm{H}, \mathrm{CH}_{3} \mathrm{CH}_{3} \underline{\mathrm{VPG}} \underline{\mathrm{VG}}\right)$.

\section{3. ${ }^{1} H$ NMR analyses}

${ }^{1} \mathrm{H}$ NMR analyses were carried out a Bruker AVANCE III HD 400 apparatus equipped with a 5 mm Bruker multinuclear z-gradient direct probe operating at $400.2 \mathrm{MHz}$ for ${ }^{1} \mathrm{H}$. ${ }^{1} \mathrm{H}$ NMR spectra were acquired in $\mathrm{D}_{2} \mathrm{O}$ at $298 \mathrm{~K}$ (128 scans). The solvent signal was used as the reference signal $(\delta=4.79 \mathrm{ppm})$. HSQC analyses were performed on a Bruker AVANCE NEO 400 spectrometer operating at $100.7 \mathrm{MHz}$, equipped with a $5 \mathrm{~mm}$ Bruker multinuclear z-gradient direct cryoprobe-head operating at $298 \mathrm{~K}$. Data processing was performed using Bruker Topspin Software. Spectra were fully assigned thanks to the chemical shifts of amino acids from the literature $[61,62]$.

\subsection{DNA and ELPs solutions preparation}

Calf-thymus DNA solutions were prepared in both DI water and $10 \mathrm{mM} \mathrm{NaCl}$ at a concentration of $1 \mathrm{~g} / \mathrm{L}$. The purified pUC19 plasmid was diluted up to $1 \mathrm{~g} / \mathrm{L}$ in deionized sterile water, and dilutions up to $0.0005 \mathrm{~g} / \mathrm{L}$ were prepared with a Tris $10 \mathrm{mM}$ buffer $(\mathrm{pH}=7.4)$. Solutions of the different ELP derivatives were prepared at $0.2 \mathrm{~g} / \mathrm{L}$ in DI water containing a stoichiometric amount of $\mathrm{HCl} 0.1 \mathrm{~N}$ (previously titrated with $0.1 \mathrm{~N} \mathrm{NaOH}$ ) on the basis of $\mathrm{NH}_{2}$ content (final $\mathrm{pH}$ around 6.0). All solutions were sealed to prevent solvent evaporation and stocked at $4{ }^{\circ} \mathrm{C}$. 


\subsection{Size exclusion chromatography (SEC) analyses}

SEC analyses of ELP derivatives were carried on a liquid chromatographic system from ThermoScientific equipped with two G4000PWXL and G3000PWXL gel columns (300 x 7.8 $\mathrm{mm}$ ) (exclusion limits from $200 \mathrm{Da}$ to $300,000 \mathrm{Da}$ ) and UV detector at a flow-rate of 0.6 $\mathrm{mL} / \mathrm{min}$. Columns temperature was maintained at $25^{\circ} \mathrm{C}$. The system includes a multi-angles light scattering detector MALS and differential refractive index detector dRI from Wyatt technology. Aqueous solvent composed by $0.3 \mathrm{M}$ acetic acid, $0.2 \mathrm{M}$ ammonium acetate and ACN $(65 / 35, v / v)$ was used as eluent. Ethylene glycol was used as flow marker. $D n / d c$ measurements were performed on the differential refractive index detector dRI from Wyatt technology by injecting $500 \mu \mathrm{L}$ of each sample dissolved in the aqueous buffer at 8,10 and 15 $\mathrm{g} / \mathrm{L}$.

\subsection{Conductimetric measurements}

Conductimetric measurements were performed with a Consort K912 conductivity instrument from Topac Inc at a constant temperature of $25 \pm 0.01{ }^{\circ} \mathrm{C}$. Conductimetric titration was used to follow ELP/DNA complex formation by adding progressively a given volume of ELP solution at $0.2 \mathrm{~g} / \mathrm{L}$ to $20 \mathrm{~mL}$ calf-thymus DNA solution at controlled $\mathrm{pH}(6.5)$ and at $0.01 \mathrm{~g} / \mathrm{L}$ under continuous stirring. Conventional slow dropwise mixing of positively charged ELPs to a negatively charged DNA solution having a known amount of DNA molecules was selected for these measurements in order to avoid the aggregate formation [63-65]. Conductivity of the solution was measured after 5 minutes of stabilization.

\section{7. $\zeta$-potential measurements}

$\zeta$-potential measurements were performed on a Malvern Zetasizer NanoZS at a temperature of $37^{\circ} \mathrm{C}$. $\zeta$-potential measurements were firstly performed in parallel to $\mathrm{pH}$ measurements to determine ELP derivatives isoelectric point in the presence of an excess of $\mathrm{HCl}$ by progressive addition of $\mathrm{NaOH}$. Then, complex formation was monitored by $\zeta$-potential measurements upon the progressive addition of ELP derivative $(0.2 \mathrm{~g} / \mathrm{L})$ into the DNA solution $(0.03,0.01$ or 0.005 $\mathrm{g} / \mathrm{L}$ ) at controlled $\mathrm{pH}$ (6.0 for calf-thymus DNA and 7.4 for pUC19 plasmid DNA), under continuous agitation. As well as for conductimetric titrations, slow dropwise mixing of positively charged ELPs to a negatively charged DNA solution was also selected [63-65]. After 
each addition, stabilization of the ELP/DNA complex was reached after $5 \mathrm{~min}$. $1 \mathrm{~mL}$ of the mixture was therefore transferred into the Zetasizer NanoZS cell, for the measurement. After each measurement, the sample was transferred back into the initial solution (to keep a nearly constant volume of ELP/DNA complex solution) before the next addition of ELP. The electrophoretic mobility of the particles was measured by the instrument and converted into $\zeta$ potential value using the classical Smoluchowski expression [66].

\subsection{Dynamic light scattering (DLS) measurements}

Dynamic light scattering (DLS) measurements were performed on a Malvern ZetaSizer Nano ZS instrument equipped with a standard HeNe laser emitting at $632.8 \mathrm{~nm}$ (Malvern, U.K.) at a $90^{\circ}$ angle with a constant position in the cuvette (constant scattering volume). An amount of $100 \mu \mathrm{L}$ of sample was introduced in a high precision quartz cell with a light path of $3 \times 3 \mathrm{~mm}^{2}$. The correlation functions were averaged from three measurements of 10 runs (30 sec each one) at a temperature of $37{ }^{\circ} \mathrm{C}$ after a 2 min-temperature equilibration time. The corresponding hydrodynamic radius was determined using the Stokes-Einstein equation assuming spherical particles [67].

\subsection{Agarose gel electrophoresis.}

DNA/ELPs binding assays were evaluated by gel retardation assays. Briefly, 95 or $100 \mathrm{ng}$ of pUC19 plasmid DNA linearized by BamHI digestion were mixed with increasing amounts of ELP derivative $(0.2 \mathrm{mg} / \mathrm{mL})$ in $20 \mu \mathrm{L}$ of a mixture of buffer $(5 \%$ glycerol, $1 \mathrm{mM}$ EDTA, 10 $\mathrm{mM}$ Tris- $\mathrm{HCl} \mathrm{pH}$ of 7.4, $1 \mathrm{mM}$ dithiotreitol and $20 \mathrm{mM} \mathrm{KCl}$ ) and water (at $1 / 9 \mathrm{v} / \mathrm{v})$. DNA/ELPs complexes were incubated under stirring for $30 \mathrm{~min}$ at room temperature. $3 \mu \mathrm{L}$ of loading buffer (0.1 mM EDTA, $0.05 \%$ bromophenol blue, $50 \%$ glycerol) was then added to the mixture, and $10 \mu \mathrm{L}$ was applied to a $1.2 \%$ agarose gel in $1 \mathrm{x}$ TAE buffer $(40 \mathrm{mM}$ Tris, 20 mM acetic acid, 1 mM EDTA). SYBR ${ }^{\circledR}$ Safe (Life Technologies, CA, USA) was used to reveal the DNA bands.

In a set of experiments, Sodium dodecyl sulfate (SDS) was used to test the stability of DNA/ELP complexes [68]. DNA/ELPs complexes were prepared as describe above, then, $3 \mu \mathrm{L}$ of SDS (from 0.1 to $0.5 \mathrm{wt}$ \%) were added to the sample to denature the polypeptides. 
Afterwards, $3 \mu \mathrm{L}$ of loading buffer were added to the mixture and an aliquot of $10 \mu \mathrm{L}$ was applied to the $0.6 \%$ agarose gel electrophoresis in $1 \mathrm{x}$ TAE buffer. In several experiments, the influence of $\mathrm{NaCl}$ was evaluated. Increasing amounts of the cationic ELPs were incubated with the plasmid DNA for 30 min as described above, and $\mathrm{NaCl}$ was then added to reach a final concentration of 0-0.2 M. Tubes were incubated for an additional $30 \mathrm{~min}$ at room temperature. Then, loading buffer was added, and samples were separated in agarose gels as described above.

\subsection{Atomic force microscopy (AFM) measurements}

AFM measurements were performed at room temperature in a dry state using a Multimode $8^{\mathrm{TM}}$ microscope (Veeco Instruments Inc.). Both topographic and phase images of individual particles were obtained in Tapping Mode TM using rectangular silicon cantilever (AC 160-TS, Atomic Force, Germany) with a spring constant of $26 \mathrm{~N} / \mathrm{m}$, a resonance frequency lying in the 270-320 $\mathrm{kHz}$ range and a radius of curvature of less than $10 \mathrm{~nm}$. Samples were prepared by solvent casting at ambient temperature from a stock solution $(0.03 \mathrm{mg} / \mathrm{mL})$. A drop $(4 \mu \mathrm{L})$ of solution was deposited onto freshly cleaved mica and allowed to dry under nitrogen flow during several minutes. Measurements of diameter and height were taken using the section Particle Analysis tool provided with the AFM software (Nanoscope Analysis V1.20 from Bruker).

\subsection{Transmission Electron Microscopy (TEM).}

TEM images were acquired on a Hitachi $\mathrm{H} 7650$ microscope working at $80 \mathrm{kV}$ and equipped with an ORIUS SC1000 11MPx camera. Samples were prepared by direct deposition of a ELP($\mathrm{NH}_{2}$ )/DNA complex sample droplet on carbon grids (300 mesh Cu-300LD from Pacific Grid Tech). After 10 min the rest of liquid was removed using a filter paper. Different charge ratios, $\mathrm{R}=(\mathrm{N}+\mathrm{S}) / \mathrm{P}$, were selected for the imaging.

\subsection{Fourier-transform infrared spectroscopy (FTIR)}

FTIR measurements were performed on a FTIR Bruker Vertex 70 spectrometer at room temperature with an ATR Diamond point in Transmission mode. A drop of each sample (2aminoethylazide, or (2-azidoethyl)methylamine) was used to perform each measurement. OPUS Software was used for data analysis.

\subsection{Transition temperature measurements.}


Transition temperatures $\left(T_{t}\right)$ were determined by measuring the turbidity at $600 \mathrm{~nm}$ between 15 and $20{ }^{\circ} \mathrm{C}$ at a scan rate of $1{ }^{\circ} \mathrm{C} / \mathrm{min}$ for ELP, ELP(-CCH), ELP(-NH 2$)$ and $\operatorname{ELP}\left(-\mathrm{NHCH}_{3}\right)$ at $100 \mu \mathrm{M}$ and $1 \mathrm{mM}$ in Tris $10 \mathrm{mM}$ buffer ( $\mathrm{pH}$ 8.0). Data were collected on a Cary $100 \mathrm{UV}-\mathrm{Vis}$ spectrophotometer equipped with a multicell thermoelectric temperature controller from Agilent Technologies (FR). The $T_{t}$ was determined as the onset temperature on the plot DO (600 nm) versus temperature.

\section{Results and discussion}

\subsection{Synthesis of pH-responsive cationic ELPS.}

pH-responsive and positively-charged ELPs featuring either primary amine $\left(-\mathrm{NH}_{2}\right)$ or secondary amine $\left(-\mathrm{NHCH}_{3}\right)$ units were synthetized in two steps from the recombinant ELP with the sequence MW[VPGVGVPGMG(VPGVG) $]_{10}$. (Scheme 1) This $17 \mathrm{kDa}$ ELP featuring valine or methionine at the guest residue position (Scheme 1a) can be obtained in good yield by recombinant production in Escherichia coli bacteria and subsequent purification from the cytoplasmic soluble fraction by Inverse Transition Cycling [45,54,55]. The ELP was chemoselectively modified onto the methionine residues' side chain (11 total in the sequence) to introduce either primary or secondary amine groups (Scheme 1b). In the first step, methionine residues were alkylated using glycidyl propargyl ether to position alkyne handles [55] for subsequent coupling in the second step with azido-functionalized amines (i.e. 2aminoethylazide and (2-azidoethyl)methylamine) using copper-catalyzed azide-alkyne cycloaddition (CuAAC) [69,70] (Figures S1 and S2). 2-aminoethylazide and (2azidoethyl)methylamine) were synthesized according to previously reported procedure and characterized by ${ }^{1} \mathrm{H}$ NMR and IR spectroscopy (Figures S3 - S5). The CuAAC reaction was achieved using similar conditions to those described by Deming et al. for the modification of alkyne-functionalized statistical copolymers of Met and Lys (i.e., $\mathrm{H}_{2} \mathrm{O}, \mathrm{Cu}(\mathrm{II}) \mathrm{SO}_{4}$, sodium ascorbate, PMDTA) [71]. A reaction time of 72 hours and excess reagents of 1.5 equiv. azidoamines per Met residue was necessary to achieve quantitative couplings onto ELP(-CCH). 


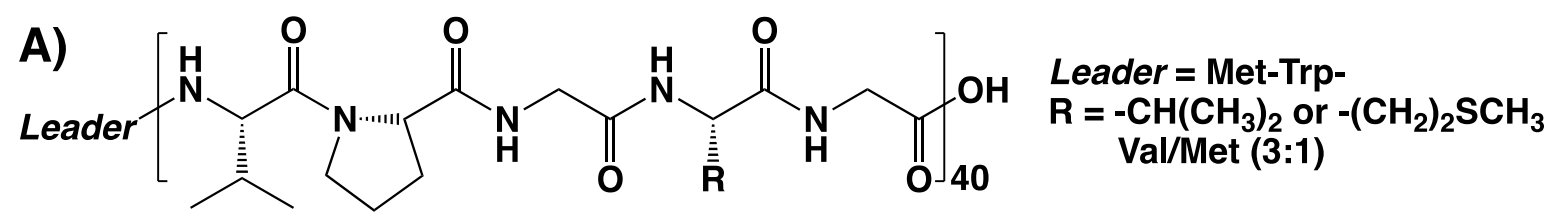

\section{B)}
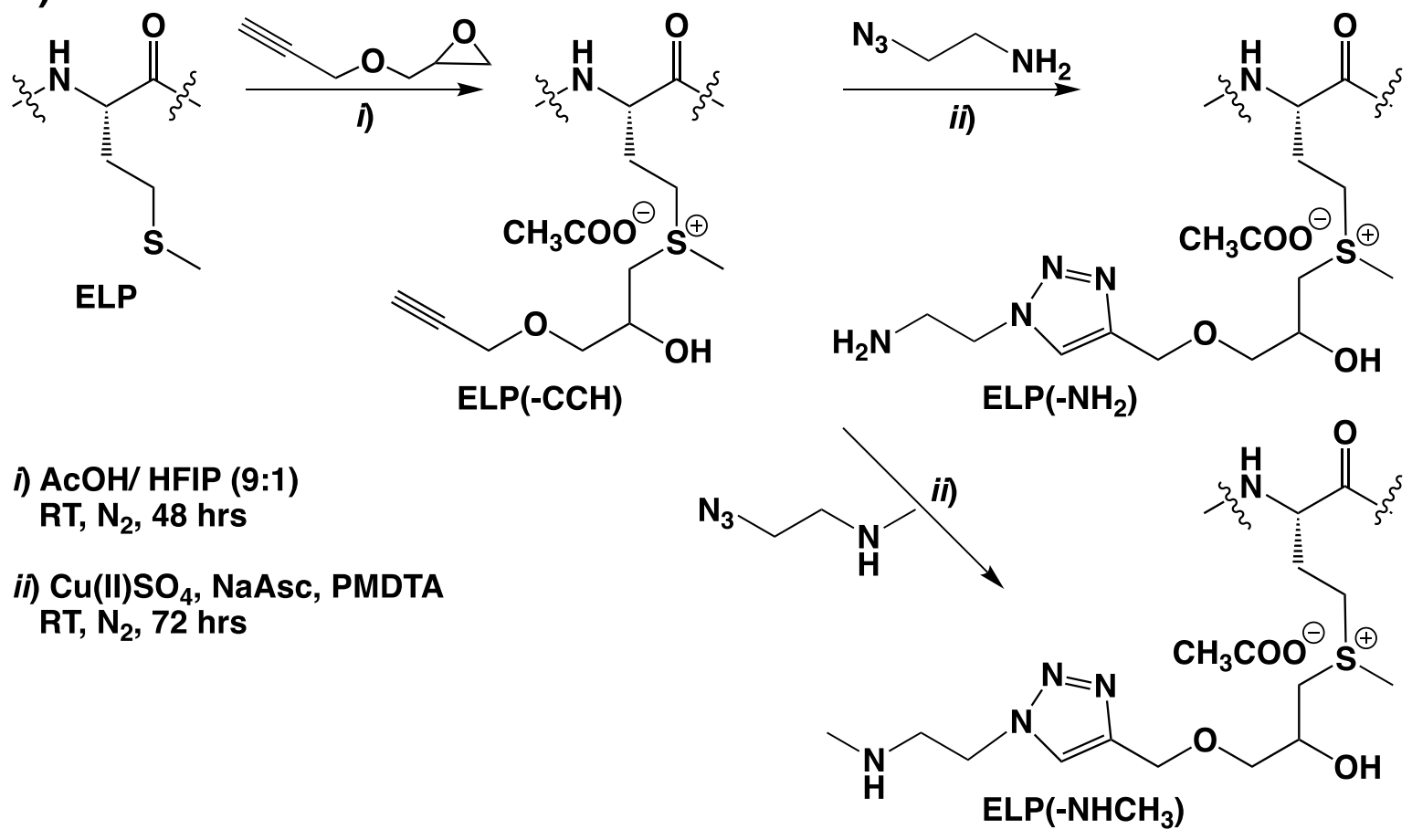

Scheme 1. A) Chemical structure of the native ELP. B) Simplified reaction scheme of the synthesis of ELP(-CCH) by chemoselective thioalkylation of ELP with glycidyl propargyl ether and of $\operatorname{ELP}\left(-\mathrm{NH}_{2}\right)$ and $\operatorname{ELP}\left(-\mathrm{NHCH}_{3}\right)$ by $\mathrm{CuAAC}$.

A degree of functionalization of $99 \%$ for ELP(-CCH) was determined by ${ }^{1} \mathrm{H}$ NMR spectroscopy analysis following the method described previously by Petitdemange et al. (Figure S6 and S7) [55]. Quantitative coupling with azido-amine reagents was also assessed by ${ }^{1} \mathrm{H}$ NMR spectroscopy. ${ }^{1} \mathrm{H}$ NMR spectra were calibrated using the resonances centered at $4.45 \mathrm{ppm}$, corresponding to $\alpha \mathrm{CH}$ protons of proline and of the first valine in each ( $\mathrm{VPGXG}$ ) repeat unit, integrating for 80 protons total. The complete disappearance of the resonance at $4.3 \mathrm{ppm}$, corresponding to the methylene group in $\alpha$ position to the alkyne function of ELP(-CCH) as well as the appearance of a resonance at $8.2 \mathrm{ppm}$ attributed to the proton of the triazole ring, integrating for 11 protons confirmed a 100\% functionalization degree for both ELP derivatives, i.e. $\mathrm{ELP}\left(-\mathrm{NH}_{2}\right)$ or $\mathrm{ELP}\left(-\mathrm{NHCH}_{3}\right)$, as shown in supporting information (Figure $\mathbf{S 8}$ and $\mathbf{S 9}$ ). 


\subsection{Characterization of positively charged ELPS}

Three positively charged ELP derivatives were therefore synthesized, namely ELP(-CCH) featuring sulfonium groups, $\operatorname{ELP}\left(-\mathrm{NH}_{2}\right)$ and $\operatorname{ELP}\left(-\mathrm{NHCH}_{3}\right)$ presenting sulfonium and amine groups. They were analyzed using different techniques to confirm their molecular weights (MW), determine their isoeletric points (IP), total number of charges and thermal responsiveness.

The different ELP derivatives were first analyzed by gel electrophoresis (SDS-PAGE) and size exclusion chromatography (SEC) to confirm MW shifts between the native recombinant ELP, the $\operatorname{ELP}(-\mathrm{CCH})$ intermediate and the $\operatorname{ELP}\left(-\mathrm{NH}_{2}\right)$ and $\operatorname{ELP}\left(-\mathrm{NHCH}_{3}\right)$ derivatives. Gel electrophoresis was used to separate the different ELP samples and therefore to roughly evaluate the molecular weight of the chemoselectively modified ELPs [72]. This analysis evidenced a slight increase in molecular weight of the ELP(-CCH) intermediate as compared to the native ELP and of the $\operatorname{ELP}\left(-\mathrm{NH}_{2}\right)$ and $\operatorname{ELP}\left(-\mathrm{NHCH}_{3}\right)$ derivatives as compared to $\operatorname{ELP}(-$ $\mathrm{CCH}$ ) (Figure 1a) [72]. The molecular weight shifts along each step of chemical postmodifications of the ELP were also followed by SEC measurements in aqueous solvent using four detectors (RI, SEC-MALS, Viscosity, UV) (Figure 1b) [73,74]. SDS-PAGE and SEC analyses also evidenced the presence of dimers in the case of positively-charged ELPs, namely ELP(-CCH), ELP(- $\left.\mathrm{NH}_{2}\right)$ and ELP(-NHCH $\left.{ }_{3}\right)$. The exact nature of these dimers (covalent versus non-covalent) is however not clear. The formation of a covalent dimer is unlikely to occur under these reaction conditions and dimer species were not detected by ESI-MS analyses. We therefore hypothesize ELPs derivatives to slightly aggregate and form SDS-resistant noncovalent dimers. Table 1 summarizes the data obtained for ELP(-CCH), ELP(-NH $\left.\mathrm{N}_{2}\right)$ and ELP($\mathrm{NHCH}_{3}$.

The different ELP derivatives were also characterized through $\zeta$-potential measurements and potentiometric titrations in order to assess their global charge as a function of $\mathrm{pH}$ [75], as well as to give a first approximation of their isoelectric point (IP). Figure 1c shows the $\zeta$-potential and potentiometric titration with $0.01 \mathrm{~N} \mathrm{NaOH}$ of each ELP derivative (i.e. ELP, ELP(-CCH), $\operatorname{ELP}\left(-\mathrm{NH}_{2}\right)$ and $\left.\operatorname{ELP}\left(-\mathrm{NHCH}_{3}\right)\right)$. For instance, the solution of fully protonated $\operatorname{ELP}\left(-\mathrm{NH}_{2}\right)$, prepared with a stoichiometric amount of $\mathrm{HCl} 0.1 \mathrm{~N}$ on the basis of $-\mathrm{NH}_{2}$ content, presented an initial $\zeta$-potential around $+23 \mathrm{mV}$ at $\mathrm{pH} 6.0$, implying fully positively charged species. Upon 
the progressive addition of $\mathrm{NaOH} 0.01 \mathrm{~N}$, the fraction of ammonium $\left[\mathrm{NH}_{3}{ }^{+}\right]$decreased progressively until null charge at a $\mathrm{pH}$ value of 10.14 when the $\zeta$-potential decreased down to zero. This value can be related to the average pKa of primary amine groups, i.e. 10.77. This allowed to determine a IP for ELP(- $\left.\mathrm{NH}_{2}\right)$ of 10.14. Similarly, the PI of ELP(-CCH) and ELP($\left.\mathrm{NHCH}_{3}\right)$ at zero $\zeta$-potential was found at 10.74 and 10.22 (Table 1). ELP(- $\left.\mathrm{NHCH}_{3}\right)$ isoelectric point was found to be close to the pKa value of the secondary amine introduced at the methionine residues of the ELP chain, i.e. 10.98 [76]. At a pH of 6.0, ELP(- $\left.\mathrm{NHCH}_{3}\right)$ and ELP($\mathrm{CCH}$ ) presented a $\zeta$-potential of around $+12 \mathrm{mV}$ and $+5.8 \mathrm{mV}$, respectively, showing that ELP(-CCH) is weakly positively charged and ELP $\left(-\mathrm{NH}_{2}\right)$ is the most positively charged of all ELP derivatives. Other polycations such as chitosan, which have very high $\zeta$-potentials at full protonation (between $+40 \mathrm{mV}$ and $+70 \mathrm{mV}$ depending on chitosan's degree of acetylation and molecular weight) $[19,75,77]$ or as the highly positively charged polyethylenimine (PEI) [78], can destabilize cell membrane at high charge ratios. However, positively charged ELP derivatives synthetized in this work, having a $\mathrm{pH}$ sensitive character and a charge density tunable through chemoselective post-modifications using different positively charged functional groups, could represent an interesting alternative for oligonucleotides or siRNA delivery [79]. Finally, for the starting ELP, the determined IP is equal to 5.65, which is very close to the theoretically determined IP, i.e. 5.27 [80]; besides, its highest $\zeta$-potential value is only around + $7.0 \mathrm{mV}$ for the lower values of $\mathrm{pH}$. Furthermore, from Figure 1c, the degree of protonation of each $\mathrm{pH}$-responsive ELP can also be determined at a given $\mathrm{pH}$ allowing in the following to express the charge ratio characterizing DNA/ELPs complex formation in the presence of highly negatively charged DNA. 

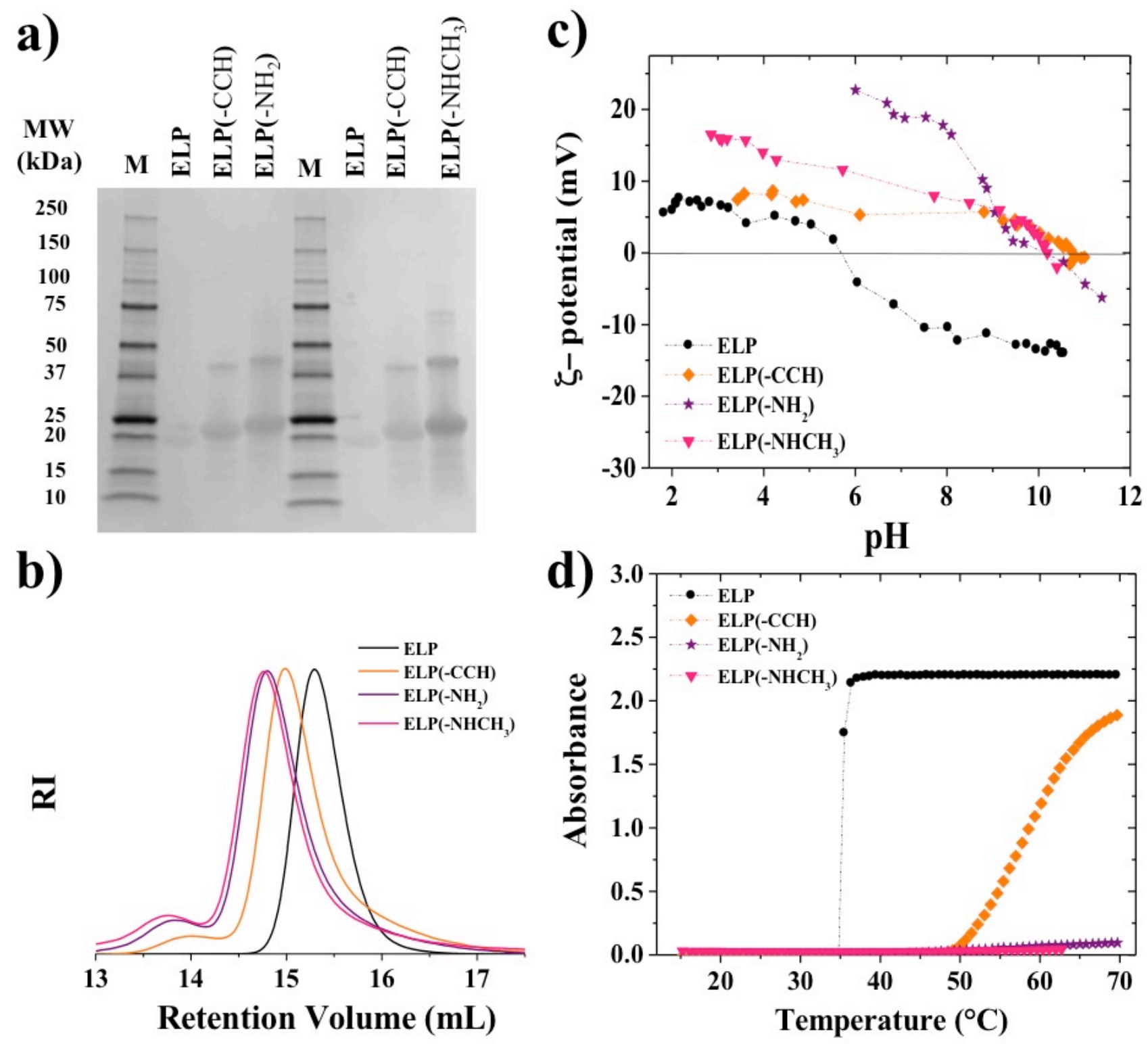

Figure 1. a) SDS-PAGE (4-20\%) analysis of ELP, ELP(-CCH), ELP(-NH $\left.\mathrm{NH}_{2}\right)$ and ELP($\mathrm{NHCH}_{3}$ ), the protein bands were revealed by coloration with colloidal coomassie $\left(\right.$ InstantBlue ${ }^{\mathrm{TM}}$ ) b) Size exclusion chromatograms in AcOH/Ammonium Acetate/ACN of ELP (black), ELP(-CCH) (orange), ELP(-NH$)$ (purple) and $\operatorname{ELP}\left(-\mathrm{NHCH}_{3}\right)$ (pink) using a RI detector, c) $\zeta$-potential and potentiometric titration of $100 \mu \mathrm{M}$ ELPs samples (dissolved in $\mathrm{HCl}$ ) with $0.01 \mathrm{~N} \mathrm{NaOH}$, d) Absorbance (\%) at $600 \mathrm{~nm}$ as a function of temperature of $100 \mu \mathrm{M}$ solutions of ELP in Tris $10 \mathrm{mM}$ buffer. SDS-Page and SEC experiments were performed at least three times. $\zeta$-potential experiments were performed in duplicate. 
Table 1. Characteristics of ELP derivatives. Molecular weight and \% of dimerization determined by SDS-PAGE analysis and SEC measurements (using dn/dc), isoelectric point (IP) determined by potentiometric titrations and $\zeta$-potential measurements and $T_{t}$ determined by absorbance as a function of temperature measurements.

\begin{tabular}{|c|c|c|c|c|c|c|c|c|}
\hline \multirow{2}{*}{$\begin{array}{c}\text { ELP } \\
\text { derivative }\end{array}$} & \multirow[b]{2}{*}{$\begin{array}{l}\text { Theoretical } \\
\text { MW (g/mol) }\end{array}$} & \multirow{2}{*}{$\begin{array}{c}{ }^{1} \text { H NMR } \\
\text { MW } \\
(\mathrm{g} / \mathrm{mol})^{\mathrm{a}}\end{array}$} & \multirow{2}{*}{$\begin{array}{c}\text { SDS-PAGE } \\
\text { Apparent MW } \\
{\text { (Da })^{b}}^{b}\end{array}$} & \multicolumn{2}{|c|}{ SEC } & \multirow[b]{2}{*}{ IP } & \multicolumn{2}{|c|}{$T_{t}\left({ }^{\circ} \mathrm{C}\right)$} \\
\hline & & & & $d n / d c^{c}$ & $\underset{(\mathbf{g} / \mathbf{m o l})^{d}}{\mathbf{M W}}$ & & $100 \mu \mathrm{M}$ & $1 \mathrm{mM}$ \\
\hline ELP & 17035.4 & 17035.4 & 19500 & 0.139 & 17370 & 5.65 & 35 & 28 \\
\hline ELP(-CCH) & 18279.9 & 18279.1 & 21200 & 0.136 & 18370 & 10.74 & 48 & 41 \\
\hline $\mathrm{ELP}\left(-\mathrm{NH}_{2}\right)$ & 19226.9 & 19226.1 & 23800 & 0.128 & 20040 & 10.14 & ND & ND \\
\hline $\mathrm{ELP}\left(-\mathrm{NHCH}_{3}\right)$ & 19381.2 & 19380.4 & 22500 & 0.128 & 21398 & 10.22 & ND & ND \\
\hline
\end{tabular}

${ }^{a}$ Molecular weights of ELP derivatives were estimated from ${ }^{1} \mathrm{H}$ NMR measurements taking the molecular of the initial ELP (confirmed by MS) to calibrate the spectrum [46]. For this purpose, the \% of functionalization was multiplied by 11 available methionines and by the molecular weight of the respective functional group grafted for each chemical post-modification (alkynes, primary and secondary amines), then added to the initial ELP molecular weight.

${ }^{b}$ Molecular weights of ELP derivatives were estimated by gel electrophoresis from the intensity of the band by using the Image Lab Software ${ }^{\circledR}$ in a Bio-Rad Gel Doc EZ Imager.

${ }^{c}$ Determined by size exclusion chromatography.

${ }^{d}$ Molecular weights of ELPs derivatives were determined from SEC measurements by using a multi-angle light scattering detector. The intensity of the resulting scattered light from relaxation of the molecule (collected by the detector) was measured as the Raleigh ratio $R_{\Theta}$, which is directly proportional to the molecular weight of the solute molecule scattering the light. dn/dc values were used to assess to this information

Finally, the effects of each chemoselective modification (i.e. thioalkyaltion and cycloaddition to introduce primary and secondary amines) on the thermo-responsive behavior of the resulting ELPs were evaluated by cloud point measurements with ELPs samples solubilized at $100 \mu \mathrm{M}$ and $1 \mathrm{mM}$ in Tris $10 \mathrm{mM}$ buffer at pH 8.0 and using light absorption at $600 \mathrm{~nm}$ (Figure 1d and Figure S10). Similarly to previously reported values in water [55], ELP(-CCH) was found to 
have a transition temperature ( $T_{t}$ corresponding to the temperature at the onset of turbidity) of 41 and $48{ }^{\circ} \mathrm{C}$ at $1 \mathrm{mM}$ and $100 \mu \mathrm{M}$, respectively (Table 1). As mentioned by Petitdemange et al. [55] this sharp increase in $T_{t}$ as compared to the initial ELP $\left(T_{t}=28\right.$ and $35^{\circ} \mathrm{C}$ at $1 \mathrm{mM}$ and $100 \mu \mathrm{M}$, respectively) is directly attributed to the strong increase in hydrophilicity provided by the 11 sulfonium groups introduced at the methionine residues along the ELP chain. Additional introduction of positively charged amino groups in $\operatorname{ELP}\left(-\mathrm{NH}_{2}\right)$ and $\mathrm{ELP}\left(-\mathrm{NHCH}_{3}\right)$ resulted in the loss of thermal responsiveness (no detectable $T_{t}$ ) as a result of even greater hydrophilic character brought by cationic amino groups.

\subsection{Stoichiometry of DNA/ELPS complexes in water}

DNA/ELPs complexes were prepared by using calf-thymus DNA (CT-DNA) solutions with a concentration of $0.01 \mathrm{mg} / \mathrm{mL}$, which is 23 times lower than the average of the overlap concentration $\left(\mathrm{C}^{*}\right)$ of this nucleic acid sample [59]. $\mathrm{C}^{*}$ corresponding to the threshold between dilute polymer solutions, where the coiled chains are separated from one another, and more concentrated solutions, where the chains overlap [59]. Since CT-DNA is a well-known and characterized nucleic acid sample $[59,75,81]$, it was used as model of nucleic acid in order to study the role of electrostatic interactions between positively-charged ELPs and DNA in the stoichiometry during the CT-DNA /ELPs complexation process. As mentioned in the methods section, slow dropwise mixing of positively charged ELPs derivatives to a negatively charged DNA solution was performed to avoid the aggregate formation [63-65].

It is well documented that the mixture of oppositely charged polymers leads to electrostatic interactions between both types of macromolecules and to the formation of complexes with counterions release $[75,82,83]$. Therefore, conductimetric measurements can be used to study the interactions between CT-DNA and ELPs, as well as the degree of complexation in absence of external salt. For ELP(-CCH), the charge ratio between the ionic concentration of positively charged sulfonium groups $\left[\mathrm{S}^{+}\right]$and the ionic concentration of phosphate groups $\left[\mathrm{P}^{-}\right]$(assumed to be fully ionized), i.e. $\mathrm{S} / \mathrm{P}$, allows the calculation of the stoichiometry during CT-DNA/ELP($\mathrm{CCH})$ complex formation. Since ELP(- $\left.-\mathrm{NH}_{2}\right)$ is bearing both positively charged sulfonium and primary amine groups, the total ionic concentration of positively charged groups is given by the addition of $\left[\mathrm{N}^{+}+\mathrm{S}^{+}\right]$. In this case, the stoichiometry during CT-DNA/ELP(- $\left.\mathrm{NH}_{2}\right)$ complex formation is calculated from the ratio $\left[\mathrm{N}^{+}+\mathrm{S}^{+}\right] /\left[\mathrm{P}^{-}\right]$with the simplified notation $(\mathrm{N}+\mathrm{S}) / \mathrm{P}$. For 
instance, an $\operatorname{ELP}\left(\right.$ alkyne) concentration of $2 \mathrm{~g} / \mathrm{L}$ corresponds to $\left[\mathrm{S}^{+}\right] 1.135 \times 10^{-3}$ equiv./L, and an $\operatorname{ELP}\left(-\mathrm{NH}_{2}\right)$ concentration of $2 \mathrm{~g} / \mathrm{L}$ corresponds to $\left[\mathrm{N}^{+}+\mathrm{S}^{+}\right] 2.266 \times 10^{-3}$ equiv./L. Considering the average molar mass of a nucleotide as $330 \mathrm{~g} / \mathrm{mol}$, for a $0.01 \mathrm{mg} / \mathrm{mL}$ DNA solution, [P'] equals to $3.03 \times 10^{-5}$ equiv./L.

Figure 2a shows the electrical conductivity as a function of S/P ratio during CT-DNA/ELP($\mathrm{CCH})$ mixture at a constant temperature of $25{ }^{\circ} \mathrm{C}$. Small amounts of $0.2 \mathrm{~g} / \mathrm{L}$ ELP(-CCH) bearing $100 \%$ of sulfonium groups (i.e., 11 positive charges in each ELP macromolecule) were progressively added into a $0.01 \mathrm{~g} / \mathrm{L}$ DNA solution in water at $\mathrm{pH}=6.5$. A linear increase of the conductivity during addition of ELP(-CCH) is observed with a slight change in the slope depicted at a ratio $\mathrm{S} / \mathrm{P}=1$, corresponding to the charge stoichiometry between weakly positively charged ELP(-CCH) and strongly negatively charged CT-DNA. Counterion release, (free and condensed counterion fractions), i.e. $\mathrm{Na}^{+}$for DNA and $\mathrm{CH}_{3} \mathrm{COO}^{-}$for $\mathrm{ELP}(-\mathrm{CCH})$, can be observed with the initial increase in conductivity, resulting from interactions between negatively charged CT-DNA and positively charged ELP(alkyne) [75,84]. Figure 2b shows the electrical conductivity as a function of $(\mathrm{N}+\mathrm{S}) / \mathrm{P}$ ratio during CT-DNA/ELP(- $\left.-\mathrm{NH}_{2}\right)$ complex formation (CT-DNA/ELP(-NHCH 3$)$ ) complex formation curve can be found in the SI as Figure S11). Small amounts of $0.2 \mathrm{~g} / \mathrm{L} \mathrm{ELP}\left(-\mathrm{NH}_{2}\right)$ bearing $100 \%$ sulfonium groups and fully protonated $\mathrm{NH}_{3}{ }^{+}$groups (i.e., 22 positive charges in each ELP macromolecule) were progressively added into the CT-DNA solution. A linear increase of the conductivity during addition of ELP(- $\left.\mathrm{NH}_{2}\right)$ is also observed with a change in the slope at the ratio $(\mathrm{N}+\mathrm{S}) / \mathrm{P}=1$, corresponding to the charge stoichiometry between positively charged ELP(- $\left.\mathrm{NH}_{2}\right)$ and strongly negatively charged CTDNA. After the inflection point, the lower slope can be attributed to the contribution of counterions coming from ELP(- $\left.-\mathrm{NH}_{2}\right)$ to the conductivity of the solution, phenomenon that has been also observed during chitosan/DNA complex formation [75,84]. Thus, the ratio $(\mathrm{N}+\mathrm{S}) / \mathrm{P}$ increases progressively with the addition of small amounts of $\operatorname{ELP}\left(-\mathrm{NH}_{2}\right)$ until reaching $(\mathrm{N}+\mathrm{S}) / \mathrm{P}=1$, representing complete complexation of CT-DNA. 
a)

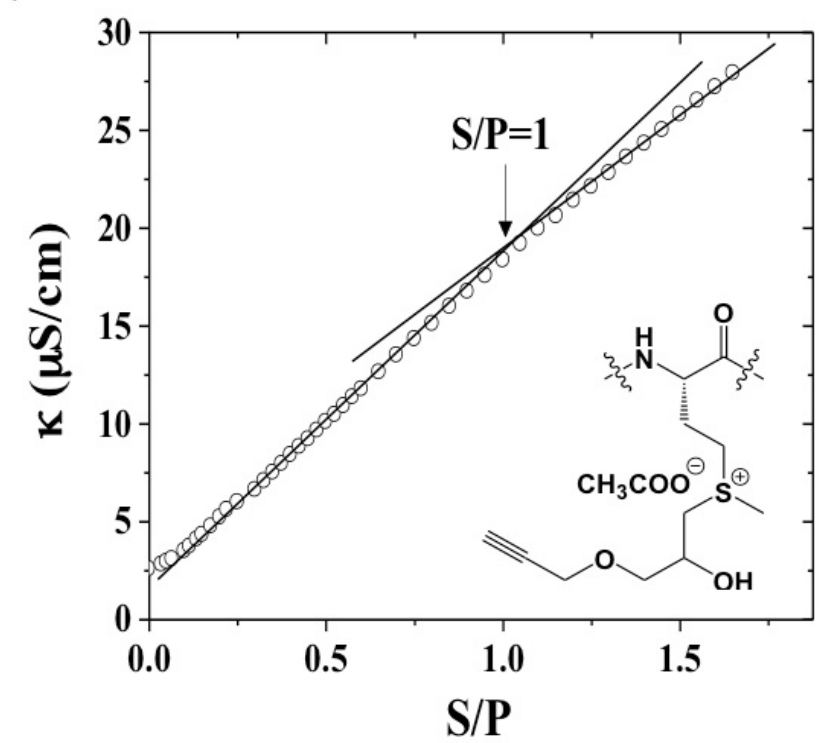

b)

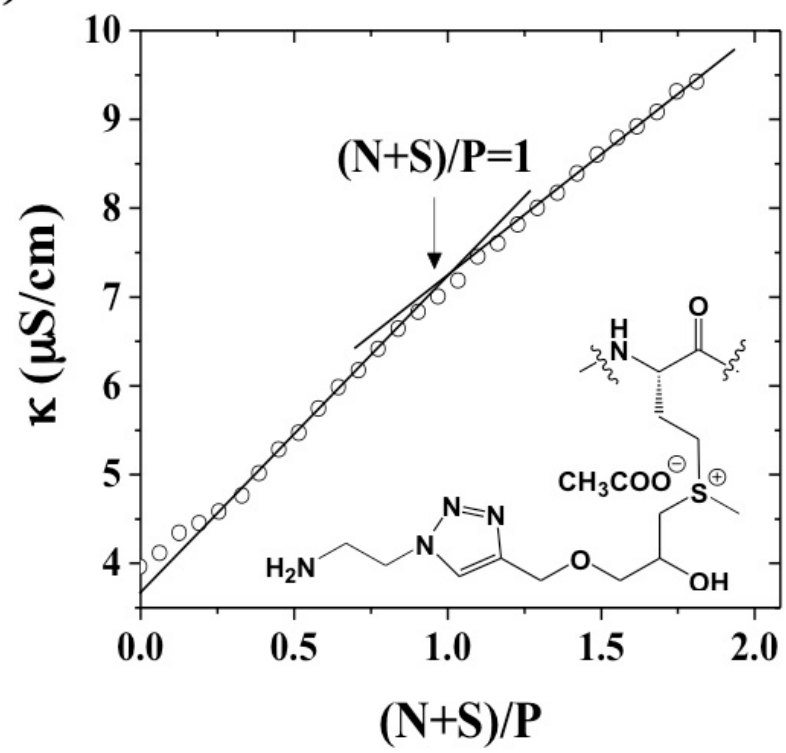

Figure 2. a) Electrical conductivity $(\kappa)$ dependence on the ratio S/P during ELP(-CCH) progressive addition to CT-DNA solution. b) Electrical conductivity ( $\kappa$ ) dependence on the ratio $(\mathrm{N}+\mathrm{S}) / \mathrm{P}$ during CT-DNA/ELP(- $\left.\mathrm{NH}_{2}\right)$ complex formation (slow dropwise mixing method). Temperature measurement: $25^{\circ} \mathrm{C} . \mathrm{C}_{\mathrm{DNA}}=0.0 .1 \mathrm{~g} / \mathrm{L}$ in water at $\mathrm{pH}=6.5, \mathrm{C}_{\mathrm{ELP}(-\mathrm{CCH})}=2 \mathrm{~g} / \mathrm{L}$ and $\mathrm{C}_{\mathrm{ELP}(-\mathrm{NH} 2)}=2 \mathrm{~g} / \mathrm{L}$, both prepared at $\mathrm{pH}=6.0$. Experiments were performed in duplicate.

In addition, as a consequence of the interactions between negatively charged DNA and cationic polymers, the charge of the complexes formed is expected to change from negative to positive. The net charge is supposed to be null when the negative charges of DNA are stoichiometrically neutralized by the positive charges of the polycation [84-86]. The crossover from a negative to a positive $\zeta$-potential corresponds to the isoelectric point of the particle formed [75,87]. Electrostatic interactions between positively charged modified ELPs (cationic/pH-responsive polymer) and CT-DNA (highly negatively charged macromolecule) were then examined during DNA complexation through electrophoretic mobility measurements. $\zeta$-potential was monitored during progressive addition of positively charged ELPs to a CT-DNA solution in water at a defined $\mathrm{pH}$, as shown in Figures 3a and $\mathbf{b}$. Using this method, polyelectrolyte complexes were formed through the addition of the cationic biopolymer to the anionic polyelectrolyte (cationic/anionic complexes) avoiding aggregates formation [63-65]. $\zeta$-potential was expected to reach zero value when $\mathrm{S} / \mathrm{P}=1$ and $(\mathrm{N}+\mathrm{S}) / \mathrm{P}=1$, for complexes formed between positively 
charged ELP(-CCH) and CT-DNA/ELP(-NH$)$ or CT-DNA/ELP(-NHCH 3$)$, respectively, with strongly negatively charged DNA. Figure 3a shows the $\zeta$-potential dependence on the ratio S/P during the addition of $\mathrm{ELP}(-\mathrm{CCH})$ at a $\mathrm{pH}=6.0$ to a CT-DNA solution at neutral $\mathrm{pH}(6.5)$, reaching the isoelectric point at $\mathrm{S} / \mathrm{P}=1$, which corresponds to the stoichiometric neutralization of CT-DNA negative charges. Since ELP(-CCH) is only weakly positively charged, as mentioned above, further additions of ELP(-CCH) after the isoelectric point, only led to $\zeta$-potential around to $+2 \mathrm{mV}$, which is a very unstable region for complexes [84].
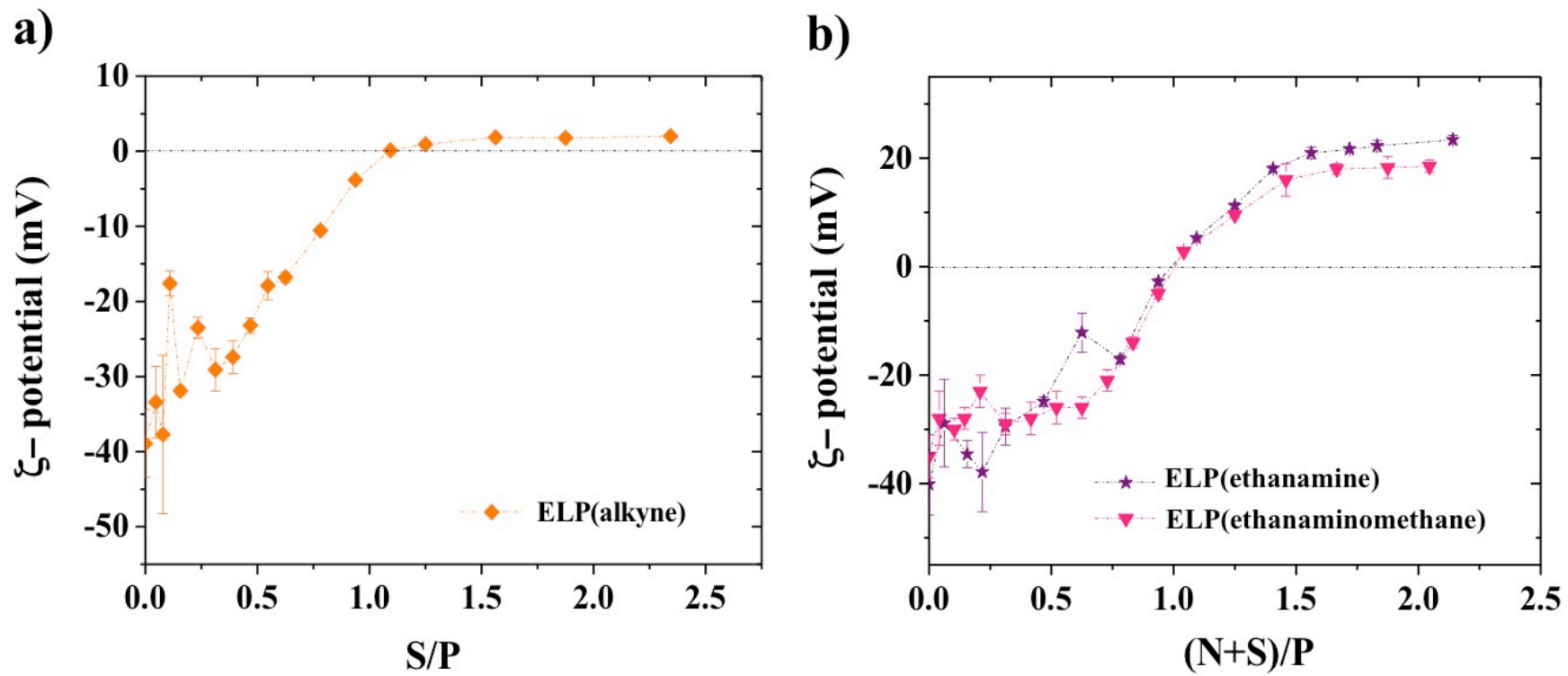

Figure 3. a) $\zeta$-potential as a function of $\mathrm{S} / \mathrm{P}$ ratio during $\mathrm{CT}-\mathrm{DNA} / \mathrm{ELP}(-\mathrm{CCH})$ interactions. b) $\zeta$-potential as a function of $(\mathrm{N}+\mathrm{S}) / \mathrm{P}$ ratio during CT-DNA/ELP(-NH$)$ and CT-DNA/ELP ($\mathrm{NHCH}_{3}$ ) complex formation (slow dropwise mixing method). Temperature measurement: 25 ${ }^{\circ} \mathrm{C} . \mathrm{C}_{\mathrm{DNA}}=0.01 \mathrm{~g} / \mathrm{L}$ in water at $\mathrm{pH}=6.5, \mathrm{C}_{\mathrm{ELP}(-\mathrm{CCH})}=0.2 \mathrm{~g} / \mathrm{L}, \mathrm{C}_{\mathrm{ELP}(-\mathrm{NH} 2)}=0.2 \mathrm{~g} / \mathrm{L}$ and $\mathrm{C}_{\mathrm{ELP}(-}$ $\mathrm{NHCH} 3)=0.2 \mathrm{~g} / \mathrm{L}$ all of them prepared at $\mathrm{pH}=6.0$. $\zeta$-potential experiments were performed in triplicate.

Figure 3b shows the $\zeta$-potential dependence on the ratio $(\mathrm{N}+\mathrm{S} /) \mathrm{P}$ during the addition of ELP($\left.\mathrm{NH}_{2}\right)$ and $\mathrm{ELP}\left(-\mathrm{NHCH}_{3}\right)$ to a CT-DNA solution at neutral $\mathrm{pH}(6.5)$, reaching, in both cases, the isoelectric point at $(\mathrm{N}+\mathrm{S}) / \mathrm{P}=1$. As well as for the CT-DNA/ELP(-CCH) system, this corresponds to the stoichiometric neutralization of CT-DNA negative charges. Further additions of $\operatorname{ELP}\left(-\mathrm{NH}_{2}\right)$ and $\operatorname{ELP}\left(-\mathrm{NHCH}_{3}\right)$ to CT-DNA solution after the isoelectric point allowed obtaining overcharging around to $+24 \mathrm{mV}$ and $+18 \mathrm{mV}$, respectively. This overcharging plateau 
is in good agreement with the ones obtained for other systems including chitosans [75,84], polyaminoacids $[88,89]$ and cationic polymers presenting dendrimer structures or linear configurations [90]. Finally, the obtained positive $\zeta$-potential for CT-DNA/ELP(-NH 2$)$ and CTDNA/ELP(- $\left.\mathrm{NHCH}_{3}\right)$ systems suggests that DNA compaction is completely accomplished with pH-responsive ELPs chains $[6,75,84]$, ELP(-NH 2$)$ being the compound yielding complexes with the greatest positive net charge at their surface and potentially displaying higher stability.

Furthermore, in both cases, the $\zeta$-potential shows the same trend, presenting an initial highly negative $\zeta$-potential around $-40 \mathrm{mV}$, corresponding to CT-DNA molecules, which decreases with the addition of the pH-responsive ELP to the CT-DNA solution. This shows that electrostatic interactions between positively charged ELPs and CT-DNA take place in the solution and represents the beginning of the complexation process of CT-DNA. Then, a first plateau at negative $\zeta$-potential values is observed around a $\zeta$-potential value of $-25 \mathrm{mV}$, attributed to a progressive formation of partially complexed CT-DNA/ELP(-NH $\left.\mathrm{N}_{2}\right)$ and CTDNA/ELP(- $\left.\mathrm{NHCH}_{3}\right)$ particles, followed by the crossover at $\zeta$-potential $=0 \mathrm{mV}$ at $(\mathrm{N}+\mathrm{S}) / \mathrm{P}=1$, corresponding to the stoichiometric equivalence of charge determined through theoretical calculations for charge equivalence and in good agreement with conductimetric measurements. Finally, the previously described overcharging plateau can be observed for $(\mathrm{N}+\mathrm{S}) / \mathrm{P}>1$. The obtained results allow concluding that electrostatic interactions between positively charged $\mathrm{pH}-$ responsive ELPs and fully ionized phosphates from CT-DNA, excluding hydrogen-bonding interactions, are responsible of CT-DNA/ELP derivatives complex formation. This statement is in good agreement with chitosan/DNA complex conception, which is formed between negatively charged phosphate groups and the fraction of protonated chitosan, and which stability can be modified in dependence of the $\mathrm{pH}[75]$.

\subsection{Charge ratio influence on net charge, dimensions and morphology of plasmid DNA/ELPs} complexes

Previously, a detailed study of the compaction process between positively charged ELPs with calf thymus DNA as nucleic acid model was performed for charge equivalence calculations, stoichiometry determination through conductivity measurements and complex formation nature 
highlighting (i.e. electrostatic interactions). With all the obtained information, the optimal conditions for the formulation of stable nanoparticles in charge and dimensions for the transfer of genetic material were determined for the formation and study of pUC19 plasmid/ELP(-NH $\left.{ }_{2}\right)$ complexes. ELP $\left(-\mathrm{NH}_{2}\right)$ was chosen due to its greatest positive net charge, suggesting the highest stability. Figure 4a shows the $\zeta$-potential dependence on $(\mathrm{N}+\mathrm{S}) / \mathrm{P}$ ratio during pUC19 plasmid/ELP(- $\left.\mathrm{NH}_{2}\right)$ complex formation. As well as for CT-DNA/ELP(-NH 2$)$ complex formation, slow dropwise mixing of $\operatorname{ELP}\left(-\mathrm{NH}_{2}\right)$ to a negatively charged DNA solution was selected to perform this experiment and avoid aggregates formation. Herein, it is observed that for larger amounts of $\operatorname{ELP}\left(-\mathrm{NH}_{2}\right)$ added to the plasmid solution, overcharging occurs with the formation of a $\zeta$-potential plateau around a value of $+15 \mathrm{mV}$. However, it is worth mentioning that this value obtained is around $+10 \mathrm{mV}$, lower than the one obtained for CT-DNA/ELP($\mathrm{NH}_{2}$ ) complex prepared in water. This is certainly due to the presence of external salt from the Tris $10 \mathrm{mM}$ buffer used to prepare then solution, which was selected to approach to physiological conditions in terms of $\mathrm{pH}$ [75]. Nevertheless, the trend was observed with similar stoichiometry, given by the ratio between positively charged $\operatorname{ELP}\left(-\mathrm{NH}_{2}\right)$ and fully ionized phosphates of plasmid.

From Figure 4b, it is possible to observe the particle size dependence of pUC19 plasmid/ELP($\mathrm{NH}_{2}$ ) complexes as a function $(\mathrm{N}+\mathrm{S}) / \mathrm{P}$ ratio. It is worth mentioning that each solution of complexes was prepared at a chosen charge ratio, avoiding passing through the isoelectric point of the particles $(\zeta$-potential $=0 \mathrm{mV})$, where aggregates tend to form [91,92]. Rapid one-shot mixing (cationic ELPs to anionic DNA) method was the selected for the preparation of pUC19 plasmid/ELP(-NH$)$ polyelectrolyte complexes. This procedure gives to polyelectrolyte complexes with small diameter and higher stability compared to the polyelectrolyte complexes prepared by a slow dropwise mixing process. Moreover, this one-shot addition of ELP(- $\left.\mathrm{NH}_{2}\right)$ solution was unaffected to the order of addition, confirming that the particle formation process is kinetically controlled [63-65]. Figure $4 \mathbf{b}$ shows the presence of two regimes of stable nanoparticles, both in size and charge, were obtained: first one before the isoelectric point of the nanoparticles, i.e. $0.5<\mathrm{R}_{(\mathrm{N}+\mathrm{S}) / \mathrm{P}}<0.8$, $\zeta$-potential $=-15 \pm 5 \mathrm{mV}$ and $\mathrm{D}_{\mathrm{H}}=158 \pm 2 \mathrm{~nm}$; and a second one in excess of positive charges, i.e. $2<\mathrm{R}_{(\mathrm{N}+\mathrm{S}) / \mathrm{P}}<10$, $\zeta$-potential $=+15 \mathrm{mV}$ and $\mathrm{D}_{\mathrm{H}}=115 \pm 25$ $\mathrm{nm}$. This second regime of nanoparticles presents interesting characteristics for nucleic acids delivery due to suitable slightly positive net charge and particle size. Indeed, as described by 
many authors, polycations with a higher number of cationic charges can more strongly destabilize cellular membrane integrity, probably due to their stronger affinity [93-95]. Therefore, to reduce the cytotoxic effects of complexes, polycations with a lower number of cationic charges are generally desired. Nevertheless, if the charge density is too low, the complex stability can be compromised due to a reduced interaction strength with DNA, as observed in the case of the ELP(-CCH) derivative.

a)

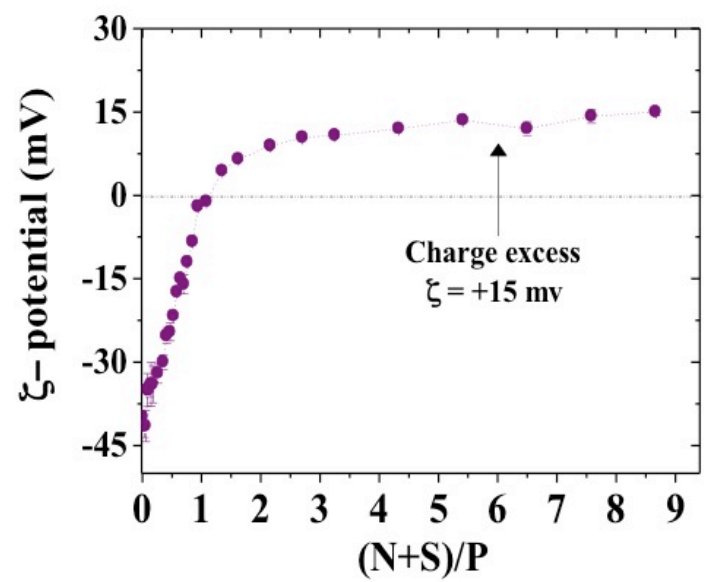

c)

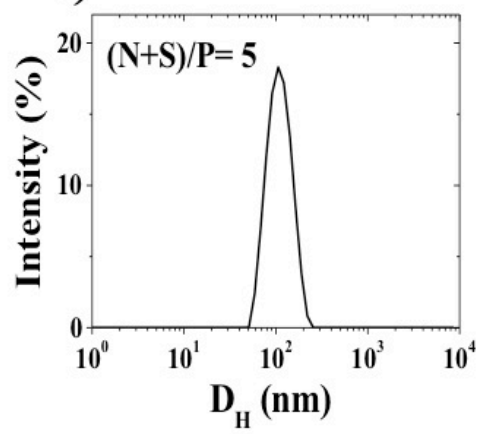

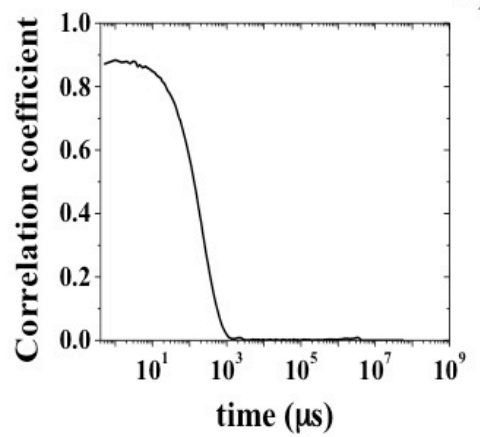

b)

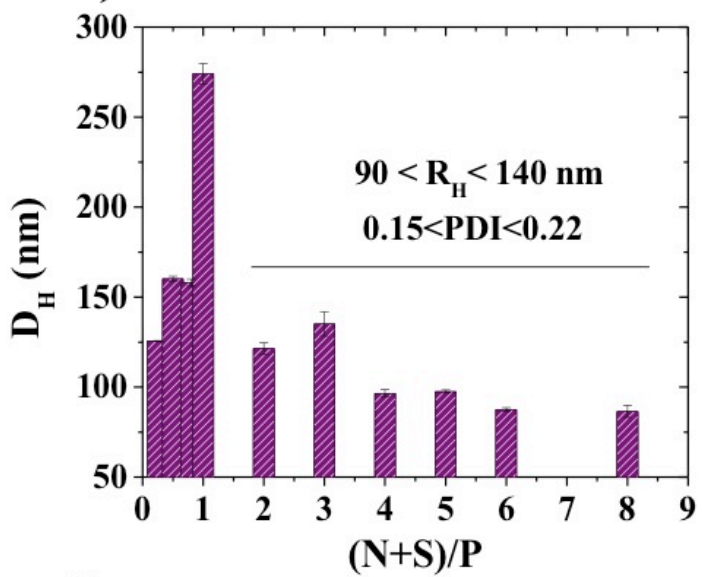

d)

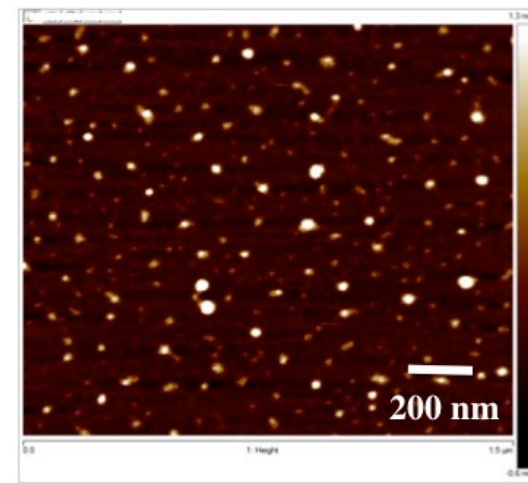

Figure 4. a) $\zeta$-potential and b) Hydrodynamic diameter $\left(\mathrm{D}_{\mathrm{H}}\right)$ as a function of $(\mathrm{N}+\mathrm{S}) / \mathrm{P}$ ratio during pUC19 plasmid/ELP(- $\left.\mathrm{NH}_{2}\right)$ complex formation. Conventional slow dropwise mixing of ELP(- $\left.\mathrm{NH}_{2}\right)$ to a DNA solution was used for $\zeta$-potential measurements. c) Intensity distribution, correlation function and d) AFM image of pUC19 plasmid/ELP(- $\left.\mathrm{NH}_{2}\right)$ complex prepared at a charge ratio of $(\mathrm{N}+\mathrm{S}) / \mathrm{P}=5$ through rapid one-shot mixing of cationic ELPs to anionic DNA. Temperature measurement: $37^{\circ} \mathrm{C} . \mathrm{C}_{\mathrm{pUC} 19}=0.005 \mathrm{~g} / \mathrm{L}$ prepared in Tris $10 \mathrm{mM}$ buffer at a

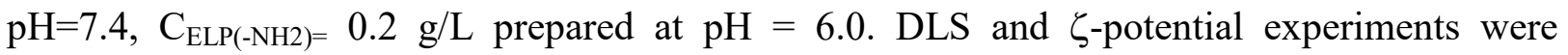
performed in triplicate. 
Figure 4c shows, as an example, the intensity distribution and the correlation function of a pUC19 plasmid/ELP $\left(-\mathrm{NH}_{2}\right)$ complex prepared at a charge ratio of $(\mathrm{N}+\mathrm{S}) / \mathrm{P}=5$. The average particle size for these complexes was found to be $98 \pm 1 \mathrm{~nm}$ with a polydispersity index (PDI) of 0.15. This value is in the range of sizes, i.e. between 100 and $200 \mathrm{~nm}$ in a buffer solution (larger than the one of a nuclear pore), where the nuclear entry of complexes having sizes between has been associated with cell division accompanied with the disappearance of the nuclear membrane [95]. From AFM measurements (Figure 4d) performed for pUC19 plasmid/ELP($\mathrm{NH}_{2}$ ) complex formed at a charge ratio $(\mathrm{N}+\mathrm{S}) / \mathrm{P}=5$, it is possible to observe that stable nanoparticles are deposited on the mica surface. The maximum apparent diameters for these pUC19 plasmid/ELP(-NH 2$)$ nanoparticles were found around $70 \pm 10 \mathrm{~nm}$.

Particle size and shape of complexes have an important role for gene delivery applications, as well as a great influence of particle distribution in the body [96]. Figure 5 shows the variation of the particle size of pUC19 plasmid/ELP $\left(-\mathrm{NH}_{2}\right)$ complex as a function of the stoichiometric ratio $(\mathrm{N}+\mathrm{S}) / \mathrm{P}$. pUC19 plasmid/ELP(-NH 2$)$ polyelectrolyte complexes were prepared by rapid one-shot mixing of ELP(-NH$)$ to a given pUC19 plasmid solution, leading to the formation of polyelectrolyte complexes with different charge ratios $(\mathrm{N}+\mathrm{S}) / \mathrm{P}$. As mentioned previously, within the range of charge ratio $(\mathrm{N}+\mathrm{S}) / \mathrm{P}$ from 0.5 to 0.8 , it is observed that the particle size is almost constant, having an average value of $158 \pm 2 \mathrm{~nm}$. Figure 5a shows the intensity distribution of pUC19 plasmid/ELP(-NH2) complex prepared at a charge ratio of $(\mathrm{N}+\mathrm{S}) / \mathrm{P}=0.5$. TEM measurements performed for pUC19 plasmid/ELP $\left(-\mathrm{NH}_{2}\right)$ complex formed at a charge ratio $(\mathrm{N}+\mathrm{S}) / \mathrm{P}=0.5$ show nanoparticles with apparent diameters around $145 \pm 22 \mathrm{~nm}$ (Figures $5 \mathbf{b}$ and 5c). In excess of added ELP(-NH $\left.\mathrm{N}_{2}\right)$ to plasmid solutions, for positively charged particles, the dimensions are lower than the ones from particles at a $(\mathrm{N}+\mathrm{S}) / \mathrm{P}<1.0$, as shown by DLS and TEM measurements for pUC19 plasmid/ELP $\left(-\mathrm{NH}_{2}\right)$ complexes prepared at a charge ratio of $(\mathrm{N}+\mathrm{S}) / \mathrm{P}=3.0$ (Figures $5 \mathbf{d}$ to $\mathbf{5 f}$ ). In agreement with DLS measurements, TEM images taken for pUC19 plasmid/ELP(-NH2) complexes formed at $(\mathrm{N}+\mathrm{S}) / \mathrm{P}=3.0$ show nanoparticles with apparent diameters around $115 \pm 16 \mathrm{~nm}$. 
a)

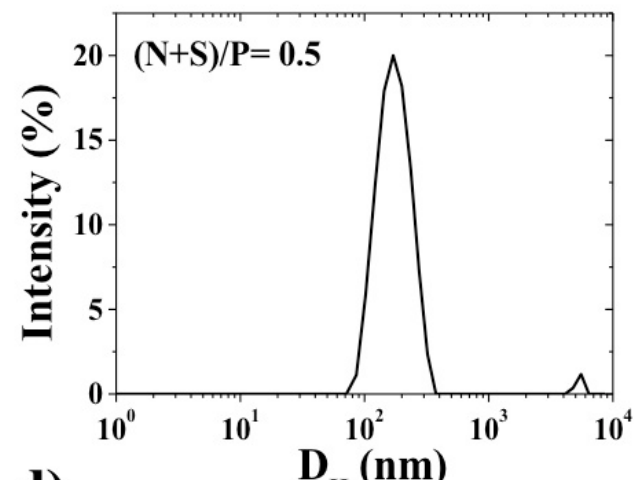

d)

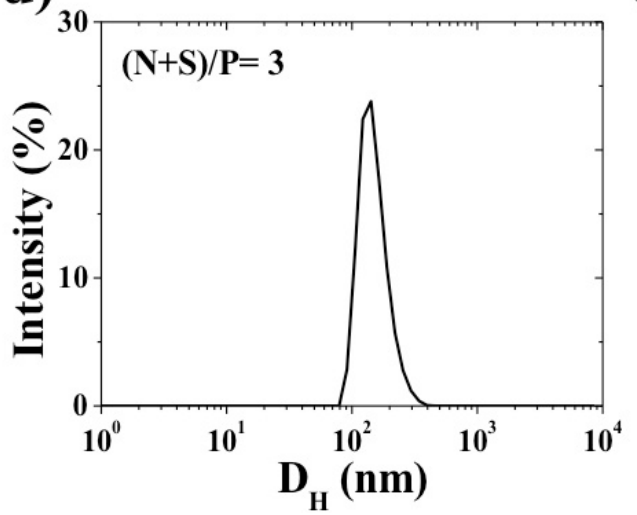

b)

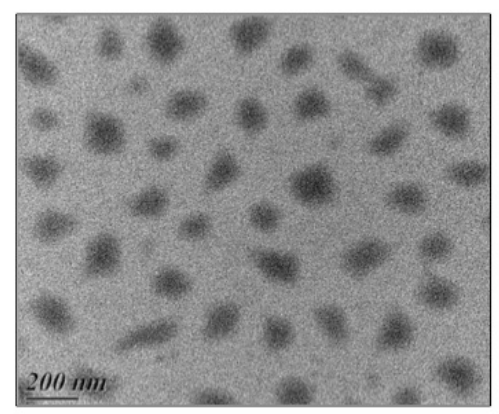

e)

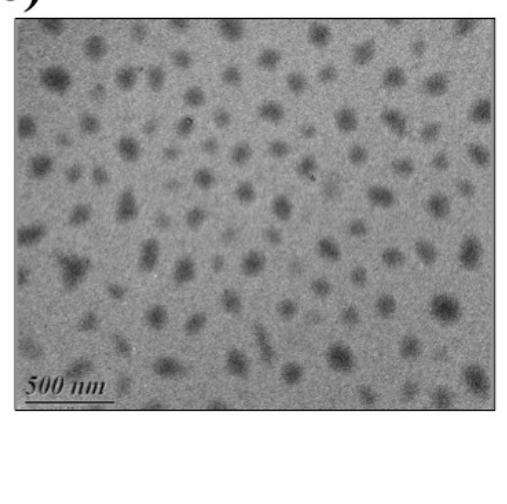

c)

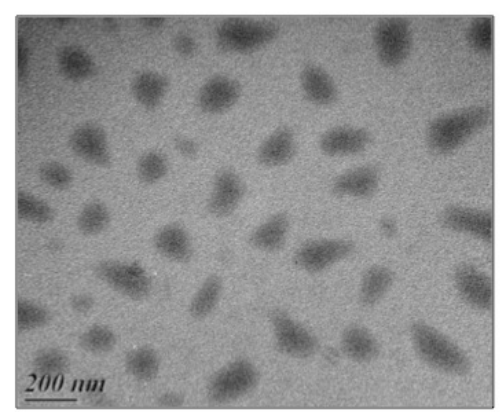

f)

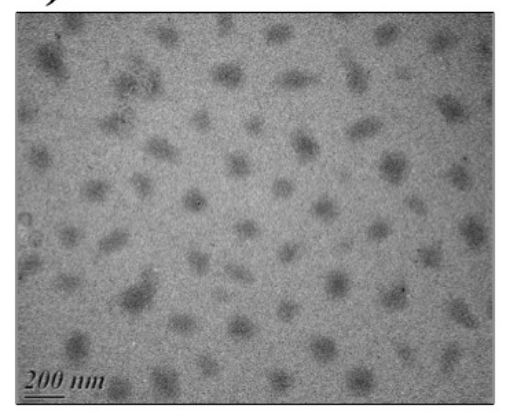

Figure 5. a) Intensity distribution as a function of size, and b) and c) TEM images of pUC19 plasmid/ELP( $\left(-\mathrm{NH}_{2}\right)$ complex prepared at a charge ratio of $(\mathrm{N}+\mathrm{S}) / \mathrm{P}=0.5$. d) Intensity distribution as a function of size, and e) and f) TEM images of pUC19 plasmid/ELP(- $\left.\mathrm{NH}_{2}\right)$ complex prepared at a charge ratio of $(\mathrm{N}+\mathrm{S}) / \mathrm{P}=3.0 . \mathrm{C}_{\mathrm{pUC} 19}=0.005 \mathrm{~g} / \mathrm{L}$ prepared in Tris $10 \mathrm{mM}$ buffer at a $\mathrm{pH}=7.4, \mathrm{C}_{\mathrm{ELP}(-\mathrm{NH} 2)}=0.2 \mathrm{~g} / \mathrm{L}$ prepared at $\mathrm{pH}=6.0$. pUC19 plasmid/ELP(-NH $\mathrm{NH}_{2}$ complexes were prepared through rapid one-shot mixing of cationic ELPs to anionic DNA.

Table 2 summarizes pUC19 plasmid/ELP(- $\left.\mathrm{NH}_{2}\right)$ complex information determined through TEM (average particle size) and DLS measurements (hydrodynamic diameter, $\mathrm{D}_{\mathrm{H}}$, scattered intensity, $\mathrm{I}_{\mathrm{SCA}}$ and $\left.\mathrm{PDI}\right)$ for two different charge ratios, $(\mathrm{N}+\mathrm{S}) / \mathrm{P}=0.5$ and 3.0, as well as their global charge obtained from electrophoretic mobility measurements. Negatively charged complexes were obtained at charge ratios $(\mathrm{N}+\mathrm{S}) / \mathrm{P}<1$, and cationic complexes were obtained at charge ratios $(\mathrm{N}+\mathrm{S}) / \mathrm{P}>1$. It is then possible to conclude that two well-characterized regimes of stable nanoparticles, both in size and charge, can be obtained from the compaction of nucleic acids with chemoselectively modified ELPs bearing positively charged ELPs featuring 
sulfonium and ammonium groups. Finally, from TEM measurements, it was possible to observe a mixture of nanoparticles with quasi-spherical and elongated shapes at $(\mathrm{N}+\mathrm{S}) / \mathrm{P}<1$ and nanoparticles with mainly quasi-spherical shapes at $(\mathrm{N}+\mathrm{S}) / \mathrm{P}>1$, in good agreement with reports from the literature [97-98]. Resulting quasi-spherical pUC19 plasmid/ELP(- $\left.\mathrm{NH}_{2}\right)$ cationic nanoparticles are probably constituted by a neutral core surrounded by a cationic ELP(-NH $\left.\mathrm{N}_{2}\right)$ shell ensuring the colloidal stabilization [99]. We suggest that a core-shell model could describe some features of our DNA/ELPs complexes obtained at different charge ratios. Core-shell polyelectrolyte complex model have been proposed for alginate-chitosan complexes [100] and for chitosan-dextran sulphate complexes [99]. For the case of chitosan-dextran sulphate combination, in the presence of an excess of cations (chitosan), dense and small nonaggregating particles were formed [99].

Table 2. pUC19 plasmid/ELP(-NH2) complex characterization through TEM (average particle size) and Dynamic Light Scattering measurements (Hydrodynamic diameter, $D_{H}$, Scattered intensity, $I_{S C A}$ and PDI) for two different charge ratios, $(N+S) / P=0.5$ and 3.0. $C_{p U C 19}=0.005$ $\mathrm{g} / \mathrm{L}$ prepared in Tris $10 \mathrm{mM}$ buffer at a $\mathrm{pH}=7.4, C_{E L P(-\mathrm{NH} 2)}=0.2 \mathrm{~g} / \mathrm{L}$ prepared at $\mathrm{pH}=6.0$. pUC19 plasmid/ELP $\left(-\mathrm{NH}_{2}\right)$ complexes were prepared through the rapid one-shot mixing method (cationic ELPs to anionic DNA).

\begin{tabular}{|c|c|c|c|c|c|}
\hline \multirow{2}{*}{$(\mathrm{N}+\mathrm{S}) / \mathbf{P}$} & \multicolumn{3}{|c|}{ DLS } & \multirow{2}{*}{$\begin{array}{c}\zeta \text {-potential } \\
(\mathrm{mV})\end{array}$} & \multirow{2}{*}{$\begin{array}{c}\text { Particle diameter } \\
\text { (nm) }\end{array}$} \\
\hline & $D_{H}(n m)$ & I SCA $_{\text {(a.u.) }}$ & PDI & & \\
\hline 0.5 & $168 \pm 10$ & $33 \pm 0.7$ & 0.160 & $-15 \pm 5$ & $145 \pm 22$ \\
\hline 3.0 & $135 \pm 5$ & $623 \pm 3$ & 0.005 & +15 & $115 \pm 16$ \\
\hline
\end{tabular}

${ }^{a}$ Determined from transmission electron micrographs.

\subsection{Detailed structure of pUC19 plasmid DNA/ELP $\left(-\mathrm{NH}_{2}\right)$ complexes as observed by AFM}

Tapping mode AFM topographs of ELP(-NH$)$ complexed with pUC19 plasmid (Figures 6a to f) showed that the structures of the obtained polyplexes depend on the selected charge ratio $(\mathrm{N}+\mathrm{S}) / \mathrm{P}$ and yield mainly globular shapes [84,91,101]. Figure 6a shows the AFM topography 
of naked pUC19 DNA plasmid in its covalently closed circular form deposited onto the freshly cleaved mica [102]. Before adding any complexing agent, only covalently closed circular pCU19 was visualized and any relaxation of DNA chain was detected. Figures $\mathbf{6 b}$ and $\mathbf{6 c}$ show AFM topographs of pUC19 plasmid DNA/ELP(- $\left.-\mathrm{NH}_{2}\right)$ anionic complexes prepared at two different charge ratios $\mathrm{R}=(\mathrm{N}+\mathrm{S}) / \mathrm{P}$ lower than the stoichiometry $\mathrm{R}=1.0$, i.e. 0.5 and 0.8 , respectively. These negatively charged complexes were prepared through the rapid one-shot mixing method by adding the specific amount of cationic ELPs to a negatively charged DNA solution. From Figure $\mathbf{6 b}$, it is possible to observe that the addition of ELP(- $\left.-\mathrm{NH}_{2}\right)$ to the DNA solution leads to the formation of pUC19 plasmid DNA/ELP(- $\left.\mathrm{NH}_{2}\right)$ complexes and to a change of DNA conformation, observed on free pUC19 plasmid DNA chains. Almost all pUC19 DNA became relaxed, presenting an open circular conformation [102,103]. This effect has also been observed through AFM measurements and electrophoresis assays for pUC19 DNA interacting with heavy metal compounds such as Rhodium (II) acetate $\left[\mathrm{Rh}_{2}\left(\mathrm{O}_{2} \mathrm{CCH}_{3}\right)_{4}\right](\mathrm{Rh} 1)$ [102], also through AFM measurements for pUC19 DNA deposited on a zwitterionic lipid surface (DPPC, Di-Palmitoyl-Phosphatidyl-Choline), where it adopts an open circular conformation in MilliQ water [104]. Figure 6c shows a pUC19 plasmid DNA/ELP(-NH $\left.{ }_{2}\right)$ complex, corresponding to a transition state before condensed complexes are formed with higher amounts of charged ELPs, in good agreement with the literature [104]. It is believed that complex formation begins at the sites where free DNA chains interact with several positively charged polycations, forming condensed knots. 


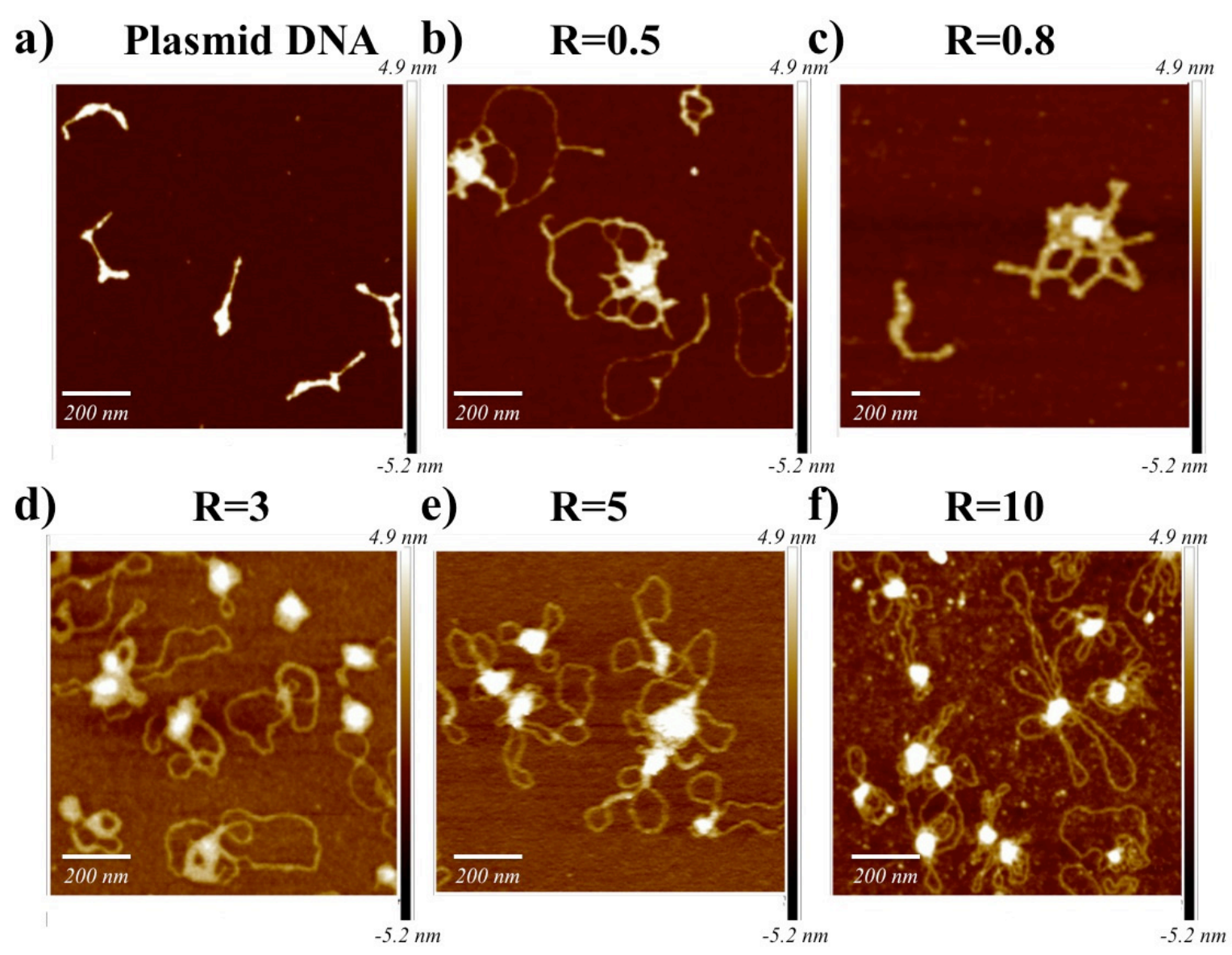

Figure 6. AFM images of a) pUC19 plasmid and pUC19/ELP(-NH $\mathrm{NH}_{2}$ complexes prepared at the following charge ratios $(\mathrm{R}=(\mathrm{N}+\mathrm{S}) / \mathrm{P})$ : b) $\mathrm{R}=0.5$, c) $\mathrm{R}=0.8$, d) $\mathrm{R}=3$, e) $\mathrm{R}=5$ and f) $\mathrm{R}=10 . \mathrm{C}_{\mathrm{pUC} 19}=$ $0.005 \mathrm{~g} / \mathrm{L}$ prepared in Tris $10 \mathrm{mM}$ buffer at a $\mathrm{pH}=7.4, \mathrm{C}_{\mathrm{ELP}}\left(-\mathrm{NH}_{2}\right)=0.2 \mathrm{~g} / \mathrm{L}$ prepared at $\mathrm{pH}=$ 6.0. pUC19 plasmid/ELP(-NH$)$ complexes were prepared through rapid one-shot mixing of cationic ELPs to anionic DNA.

Figures 6d, 6e and 6f show AFM topographs of pUC19 plasmid DNA/ELP(-NH $\left.\mathrm{NH}_{2}\right)$ cationic complexes prepared at three different charge ratio $(\mathrm{N}+\mathrm{S}) / \mathrm{P}>1.0$, i.e. 3,5 and 10 , respectively, also using the rapid one-shot mixing method. Compaction of pUC19 plasmid DNA with ELP($\mathrm{NH}_{2}$ ) yielded to globular shapes, as mentioned previously and in good agreement with the literature for other polyplexes such as DNA/chitosan complexes [84,101]. All images illustrate the higher-resolution images of polyplexes having a brush-like conformation where globules contain a dense core surrounded by some DNA chains that tend to disassemble presumably while being adsorbed to the surface. Similar globular structures have also been obtained for 
DNA complexation with transferrin-poly(L-lysine) conjugates [105] as well as for DNA complexation with chitosan [84].

\subsection{Stability assays of plasmid DNA/ELPs complexes}

To evaluate DNA-binding properties of chemoselectively modified ELPs bearing positively charged sulfonium groups and protonated amino groups, i.e. ELP(-CCH) and ELP(- $\left.\mathrm{NH}_{2}\right)$, gel retardation experiments were performed by analyzing the electrophoretic mobility of DNA (linearized pUC19 plasmid) at different charge ratios of DNA to modified ELPs on an agarose gel (Figure 7). Initial ELP was used as negative control (Figure 7a), so DNA-binding affinity with the elastin-like-polypeptide was not revealed at any ELP-to-plasmid amount reported in a mass/mass ratio, as expected for an uncharged ELP. The results obtained for ELP(-CCH), presented in Figures $\mathbf{7 b}$ and $\mathbf{7 c}$ for different charge ratio $\mathrm{S} / \mathrm{P}$, show that interactions with pUC19 plasmid are not strong enough to form a stable complex. Taking into account that pUC19 plasmid/ELP(-CCH) mixtures were left under stirring $30 \mathrm{~min}$ before running the gel retardation experiment, no complex was formed during this incubation time up to a charge ratio $\mathrm{S} / \mathrm{P}=7.5$. Oppositely, Figures $7 \mathbf{d}$ and $7 \mathbf{e}$ revealed that $\mathrm{ELP}\left(-\mathrm{NH}_{2}\right)$ and $\mathrm{ELP}\left(-\mathrm{NHCH}_{3}\right)$ were able to complex pUC19 DNA plasmid from a charge ratio $(\mathrm{N}+\mathrm{S}) / \mathrm{P}=1.0$, in good agreement with previously shown zeta potential measurements. It is then confirmed that pUC19 plasmid/ELP($\left.\mathrm{NH}_{2}\right)$ or ELP $\left(-\mathrm{NHCH}_{3}\right)$ complexes can be obtained from the interactions between positively charged ELPs and nucleic acids following the stoichiometry of charges, i.e, $(\mathrm{N}+\mathrm{S}) / \mathrm{P}=1.0$. This statement was previously demonstrated through conductivity measurements and the definite stoichiometry of complex formation is similar to that of other kind of polyelectrolytes such as chitosan and Poly-L-Lysine [75,106]. 

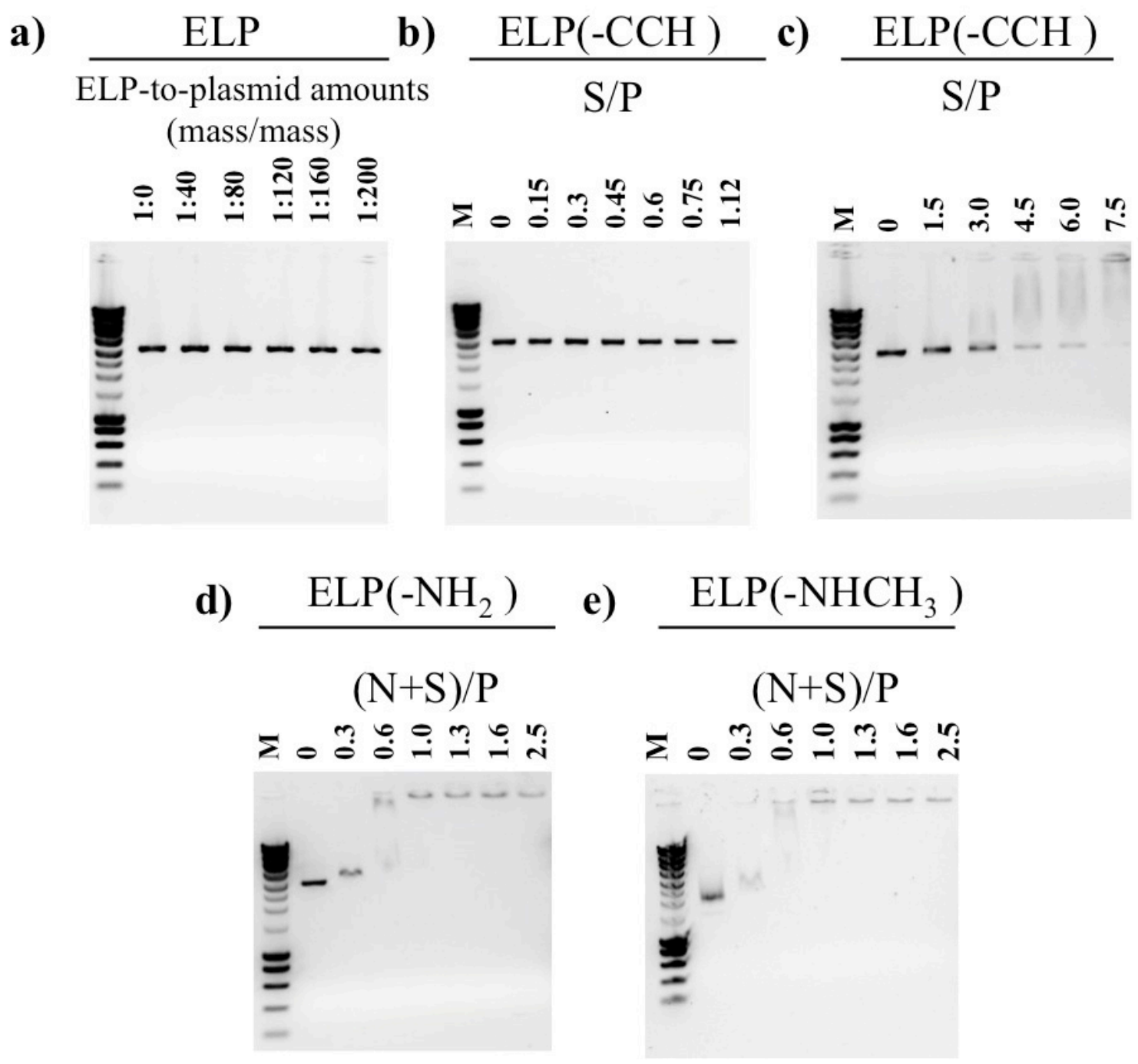

Figure 7. Electrophoresis gel assays showing the effect of a) ELP-to-plasmid amounts (mass/mass), b) and c) S/P charge ratio for ELP $(-\mathrm{CCH}), \mathrm{d})(\mathrm{N}+\mathrm{S}) / \mathrm{P}$ charge ratio for $\mathrm{ELP}\left(-\mathrm{NH}_{2}\right)$ and e) $(\mathrm{N}+\mathrm{S}) / \mathrm{P}$ charge ratio for $\operatorname{ELP}\left(-\mathrm{NHCH}_{3}\right)$ on the electrophoretic mobility of linearized pUC19 plasmid (BamHI digested). M represents the molecular weights of the marker (SmartLadder MW-1700-10 Eurogentec). $\mathrm{C}_{\mathrm{pUC} 19}=0.095 \mathrm{~g} / \mathrm{L}$ prepared in Tris $10 \mathrm{mM}$ buffer at a $\mathrm{pH}=7.4, \mathrm{C}_{\mathrm{ELP}(-\mathrm{NH} 2)}=0.2 \mathrm{~g} / \mathrm{L}$ prepared at $\mathrm{pH}=6.0$.

Stability of polyelectrolyte complexes depends on different factors such as external salt concentration, $\mathrm{pH}$ when one of the polyelectrolyte is a weak base or acid, temperature, among others [107]. The effect of external salt ( $\mathrm{NaCl}$ from 0 to $2 \mathrm{M})$ on pUC19 plasmid/ELP(-CCH) and pUC19 plasmid/ELP(-NH2) complex formation, as well as on its stability was then studied. Figure 8a presents the electrophoresis gel assays showing the effect of charge ratio $(\mathrm{S} / \mathrm{P})$ on the 
electrophoretic mobility of pUC19 plasmid with ELP(-CCH) at physiological conditions, in presence of $154 \mathrm{mM} \mathrm{NaCl}$, in which it is possible to observe that the week interaction between ELP(-CCH) and DNA was totally impaired by the presence of $\mathrm{NaCl}$. However, the interaction between $\operatorname{ELP}\left(-\mathrm{NH}_{2}\right)$ and DNA was not compromised by the presence of either $154 \mathrm{mM}$ or 370 $\mathrm{mM} \mathrm{NaCl}$ (Figure 8b and $\mathbf{c}$ ), presenting a higher stability than ELP(-CCH) and showing the importance of the provided charge from amino groups contained in the ELP backbone. Gel shift assays confirmed that pUC19 plasmid/ELP(-NH $\mathrm{NH}_{2}$ complexes were completely stable to dissociation for charge ratios up to 2.5 under physiological salt concentrations ( $154 \mathrm{mM} \mathrm{NaCl})$, indicating that the chemoselectively modified ELPs strongly condensed the DNA and protected against electrolyte-mediated dissociations. Similar behavior was reported for DNA condensed with decameric peptides containing lysine residues, which resulting complexes were also stable to dissociation under physiological conditions [108].

Figure 8d shows the electrophoresis gel assays showing the effect $\mathrm{NaCl}$ concentration on the electrophoretic mobility of pUC19 plasmid with $\operatorname{ELP}\left(-\mathrm{NH}_{2}\right)$ at a constant $(\mathrm{N}+\mathrm{S}) / \mathrm{P}$ ratio of 1.3 , confirming that in a $\mathrm{NaCl}$ concentration range from 0 to $0.2 \mathrm{M}$, pUC19 plasmid/ELP(- $\left.-\mathrm{NH}_{2}\right)$ complexes remain completely stable to dissociation. Finally, pUC19 plasmid/ELP(- $\left.\mathrm{NH}_{2}\right)$ stability was tested in presence of different concentrations of the ionic detergent sodium dodecyl sulfate, SDS, $(0.1,0.3$ and $0.5 \%)$ at a charge ratio $(\mathrm{N}+\mathrm{S}) / \mathrm{P}=1.3$. SDS is a strong detergent used to test the susceptibility of nanoplexes to dissociate. Figure 8e presents the electrophoresis gel assay showing the effect of SDS (\%) on DNA-binding properties of ELP($\mathrm{NH}_{2}$ ), from which it is possible to observe that the fraction of migrated pUC19 plasmid increase with the increase on SDS concentration. Therefore, the stability of pUC19 plasmid/ELP(-NH $\left.\mathrm{NH}_{2}\right)$ complexes gets highly affected in presence of a strong detergent such as SDS, frequently used to dissociate DNA/ligands complexes by the surfactant-sequestration method [68]. 

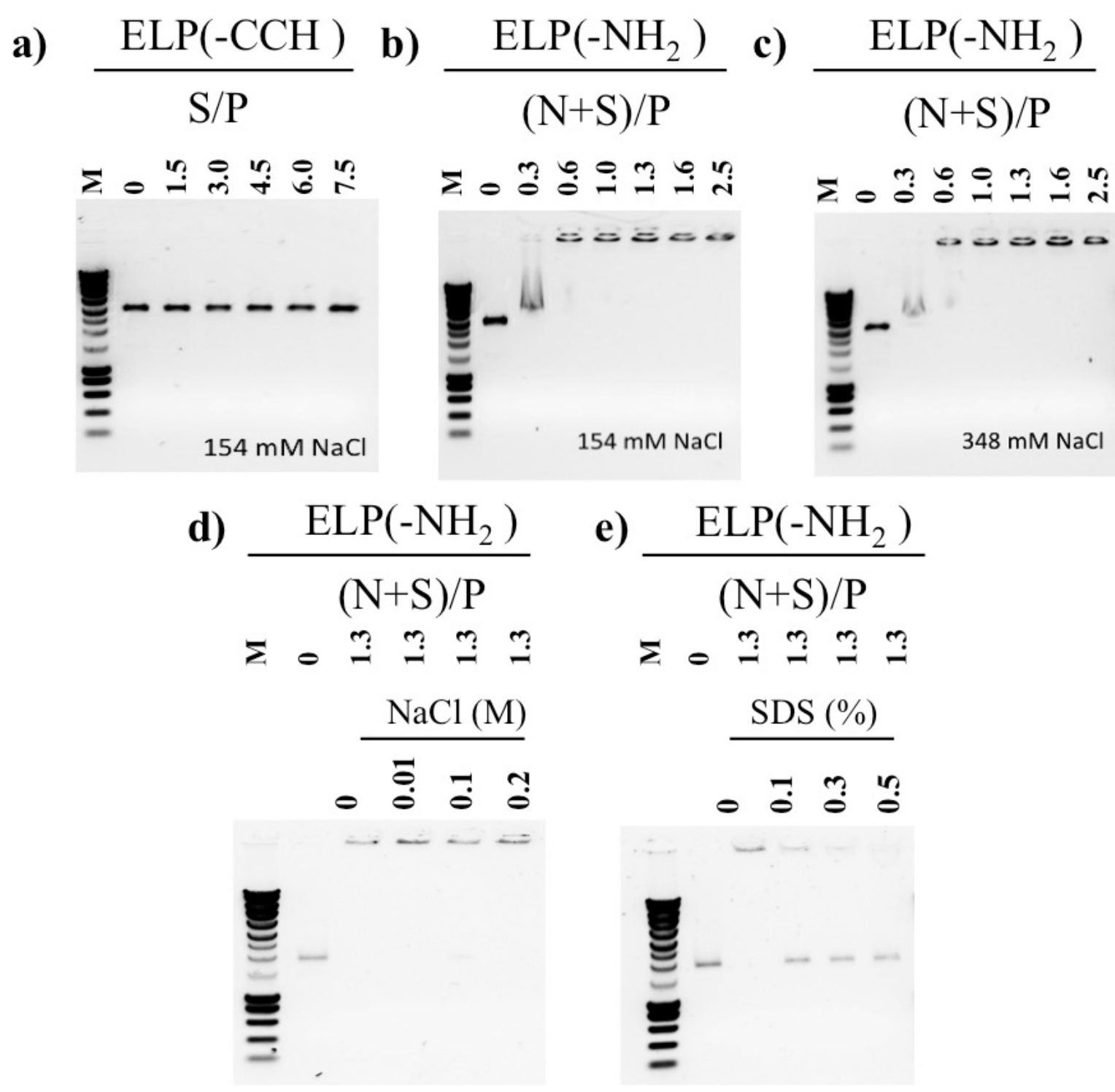

Figure 8. Electrophoresis gel assays showing the effect of charge ratio, i.e. $\mathrm{S} / \mathrm{P}$ or $(\mathrm{N}+\mathrm{S}) / \mathrm{P}$ on the electrophoretic mobility of linearized pUC19 plasmid: a) ELP(-CCH) and b) ELP(-NH$)$ in presence of $154 \mathrm{mM} \mathrm{NaCl}$ and c) $\mathrm{ELP}\left(-\mathrm{NH}_{2}\right)$ in presence of $358 \mathrm{mM} \mathrm{NaCl}$. Electrophoresis gel assays showing the effect of d) $\mathrm{NaCl}$ concentration and e) SDS (\%) on DNA-binding properties of $\operatorname{ELP}\left(-\mathrm{NH}_{2}\right)$ at a constant $(\mathrm{N}+\mathrm{S}) / \mathrm{P}$ ratio of 1.3 . M represents the molecular weights of the marker (SmartLadder MW-1700-10 Eurogentec). $\mathrm{C}_{\mathrm{pUC} 19}=0.095 \mathrm{~g} / \mathrm{L}$ prepared in Tris $10 \mathrm{mM}$ buffer at a $\mathrm{pH}=7.4, \mathrm{C}_{\mathrm{ELP}(-\mathrm{NH} 2)}=0.2 \mathrm{~g} / \mathrm{L}$ prepared at $\mathrm{pH}=6.0$. 


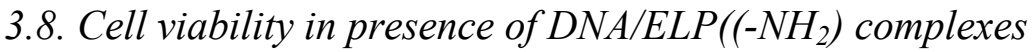

Preliminary in vitro testing of DNA/ELP $\left(-\mathrm{NH}_{2}\right)$ complexes on HEK 293 cells viability was performed in order to show that the synthetized cationic ELPs in DNA complexes forms were non cell-toxic. Cell viability was tested for different $(\mathrm{N}+\mathrm{S}) / \mathrm{P}$ ratios of DNA/ELP( $\left.-\mathrm{NH}_{2}\right)$ complexes, i.e. 10, 23 and 50. After $24 \mathrm{~h}$ of incubation, cell suspensions containing DNA/ELP($\mathrm{NH}_{2}$ ) complexes HEK 293 cells were injected on a cytometer. For $(\mathrm{N}+\mathrm{S}) / \mathrm{P}=10$, around $92 \%$ of the cells were viable, showing that toxicity remained low (Figure S12). While increasing the charge ratio up to 23, similar to the optimum transfection conditions with PEI on HEK-293 cells [109], it was observed that cell viability decreased up to $80 \%$. Based on these preliminary data, DNA/ELP(- $\left.\mathrm{NH}_{2}\right)$ complexes were found to be non cell-toxic for the purpose of this work, i.e. nucleic acids complex formation and delivery.

\section{Conclusions}

Elastin-like-Polypeptides (ELPs) are produced recombinantly, allowing the design and production of ELPs having a specific size, composition and architecture by genetic engineering. (VPGXG) 40 was selectively functionalized by alkylation at the thioether group of each methionine residue and then modified through the alkyne-azide cycloaddition click reaction to introduce additional cationic groups, either primary amines $\left(-\mathrm{NH}_{2}\right)$ or secondary amines $\mathrm{NHCH}_{3}$ ). Such an approach allows accurate control over the number of positive charges introduced to the ELP and precise determination of the stoichiometry. The average molecular weights (MW) of $\operatorname{ELP}(-\mathrm{CCH}), \operatorname{ELP}\left(-\mathrm{NH}_{2}\right)$ and $\operatorname{ELP}\left(-\mathrm{NHCH}_{3}\right)$, as well as the level of dimerization, were determined using the $d n / d c$ method. We showed that this method is more precise than SDS-PAGE analysis, giving the closest molecular weight values to those estimated through ${ }^{1} \mathrm{H}$ NMR measurements. Thermo-responsive behavior of each chemoselectively functionalized ELPs was evaluated through turbidity measurements, showing that the $T_{t}$ of alkyne-bearing epoxides with charged sulfonium groups $\left(41-48^{\circ} \mathrm{C}\right)$ are greater than those of the initial ELP $\left(28-35{ }^{\circ} \mathrm{C}\right)$; and that ELP $\left(-\mathrm{NH}_{2}\right)$ and ELP( $\left.-\mathrm{NHCH}_{3}\right)$ did not present any detectable $T_{t}$, as a result of their increased cationic and hydrophilic nature. The isoelectric point (IP) and $\zeta$ potential of the three chemoselectively modified ELPs were evaluated through electrophoretic 
mobility measurements and potentiometric titrations, from which their global charge was determined as a function of $\mathrm{pH}$. It was found that $\mathrm{ELP}(-\mathrm{CCH})$ is weakly positively charged, and that ELP $\left(-\mathrm{NH}_{2}\right)$ owns the greater positive charge of all the chemoselective modified ELPs studied here. The design of these biomacromolecules could be adapted to become novel $\mathrm{pH}-$ sensitive delivery systems.

Calf-thymus DNA was taken as a nucleic acid model to study the nature of the interactions between chemoselectively modified ELPs and a highly negative charge polyelectrolyte, i.e. DNA, as well as the stoichiometry during the complexation process. From conductimetric measurements it was determined that charge stoichiometry between positively charged ELPs and strongly negatively charged DNA corresponds to $\mathrm{S} / \mathrm{P}=1$ for $\mathrm{ELP}(-\mathrm{CCH})$ and $(\mathrm{N}+\mathrm{S}) / \mathrm{P}=1$ for ELP $\left(-\mathrm{NH}_{2}\right)$. Then, from $\zeta$-potential measurements, it was found that electrostatic interactions between ELPs and DNA take place in the solution and are responsible of the complexation process of DNA. At $\zeta$-potentials corresponding to the isoelectric point, where $\zeta$-potential $=0$ $\mathrm{mV}$, all DNA negative charges are neutralized by ELPs positive charges.

Positively charged ELPs were found to be able to interact with plasmid DNA and form stable complexes for gene delivery. $\operatorname{ELP}\left(-\mathrm{NH}_{2}\right)$ and $\operatorname{ELP}\left(-\mathrm{NHCH}_{3}\right)$ were able to complex DNA from a specific charge ratio. However, ELP(-CCH) interactions with DNA were not strong enough to form a complex, shown through $\zeta$-potential measurements and electrophoresis gel assays. Two regimes of stable nanoparticles, both in size and charge were obtained with $\operatorname{ELP}\left(-\mathrm{NH}_{2}\right)$ : one in the range of charge ratio $0.5<\mathrm{R}_{(\mathrm{N}+\mathrm{S}) / \mathrm{P}}<0.8$ with a $\zeta$-potential $=-15 \pm 5 \mathrm{mV}$ and an average size of $\mathrm{D}_{\mathrm{H}}=158 \pm 2 \mathrm{~nm}$; and a second one in excess of positive charges, i.e. $2<\mathrm{R}_{(\mathrm{N}+\mathrm{S}) / \mathrm{P}}<10$, $\zeta$ potential $=+15 \mathrm{mV}$ and $\mathrm{D}_{\mathrm{H}}=115 \pm 25 \mathrm{~nm}$. From TEM measurements, a mixture of pUC19 plasmid DNA/ELP(-NH 2$)$ negatively charged nanoparticles with quasi-spherical and elongated shapes was observed at $(\mathrm{N}+\mathrm{S}) / \mathrm{P}<1$; though, at $(\mathrm{N}+\mathrm{S}) / \mathrm{P}>1$, the morphology of pUC19 plasmid DNA/ELP $\left(-\mathrm{NH}_{2}\right)$ cationic nanoparticles were found to be mainly quasi-spherical. pUC19 plasmid DNA/ELP(-NH 2$)$ complex formation was also studied through AFM measurements at different charge ratios $(\mathrm{N}+\mathrm{S}) / \mathrm{P}$, from which it was possible to identify that the structures of the obtained polyplexes mainly yield globular shapes and depend on the charge ratios $(\mathrm{N}+\mathrm{S}) / \mathrm{P}$, in good agreement with the literature for other polyplexes such as DNA/chitosan complexes $[84,101]$. Electrophoresis gel assays confirmed that plasmid/ELP(- $\left.\mathrm{NH}_{2}\right)$ complexes were stable 
to dissociation for charge ratios up to 2.5 under physiological salt concentrations (154 mM $\mathrm{NaCl}$ ), showing that DNA was completely condensed by chemoselectively modified ELPs and protected it against electrolyte-mediated dissociations. However, it was found that the stability of plasmid/ELP(- $\left.\mathrm{NH}_{2}\right)$ complexes gets affected in presence of a strong detergent such as SDS and that the fraction of dissociated plasmid increased with the increase on SDS concentration. Finally, preliminary in vitro testing of DNA/ELP(- $\left.\mathrm{NH}_{2}\right)$ complexes on HEK 293 cells viability showed that the synthetized chemoselectively modified ELPs in DNA complexes forms were non cell-toxic.

Altogether, ELPs containing periodically spaced cationic residues, represent attractive class of biopolymers for complex formation and nucleic acids delivery since their number of cationic charges can be easily modulated and quantified. The versatility of this dual recombinant / synthetic modification approach at methionine residue also makes it possible for the introduction of other types of positively charged groups, such as small cationic peptides or oligomers as a means to tune ELP's complexation efficiency and $\mathrm{pKa}$ for the development of nanoparticles with various stability profiles.

\section{Acknowledgements}

L.M. Bravo-Anaya acknowledges the fellowship grant given by CONACYT (CVU 350759). The help of Amélie Vax and Marie Rosselin for SEC and NMR measurements, respectively, is particularly acknowledged. Electron microscopy was performed at Bordeaux Imaging Center, a service unit of the CNRS-INSERM and Bordeaux University, member of the national infrastructure France BioImaging. Campus-B project, CNRS, Univ. Bordeaux, Bordeaux INP and the Région Nouvelle Aquitaine are also acknowledged. This work was also supported by the French National Research Agency (ANR-15-CE07-0002) and the Cancéropole Grand SudOuest (Emergence 2018-E18). 


\section{Abbreviations:}

${ }^{1}$ H NMR: Proton Nuclear Magnetic Resonance

AAV: Adeno-Associated Virus

ACN: Acetonitrile

AFM: Atomic Force Microscopy

cDNAs: complementary Deoxyribonucleic Acid

CT-DNA: Calf-Thymus Deoxyribonucleic Acid

CPP: peptides

CuAAC: Copper-Catalyzed Azide-Alkyne Cycloaddition

$\mathrm{C}^{*}$ : Overlap Concentration

DNA: Deoxyribonucleic Acid

DLS: Dynamic Light Scattering

DOTAP: N-[1-(2,3-Dioleoyloxy)propyl]-N,N,N-trimethylammonium chloride

EDTA: Ethylenediaminetetraacetic acid

ELP: Elastin-like Polypeptide

ESI: Electrospray Mass Spectrometry

FITR: Fourier-Transform Infrared Spectroscopy

GFP: Green Fluorescent Protein

$\mathrm{HCl}$ : Hydrochloric acid

HFIP: Hexafluoroisopropanol

HEK cells: Human embryonic kidney cells 
hNSCs: Human Neural Stem Cells

iPSCs: Induced Pluripotent Stem Cells

IPTG: Isopropyl $\beta$-D-thiogalactopyranoside

ITC: Inverse Transition Cycling

LCST: Lower Critical Solution Temperature

MWCO: Molecular Weight Cutoff

NaAsc: Sodium Ascorbate

$\mathrm{NaOH}$ : Sodium Hydroxide

PDI: Polydispersity Index

PEI: Polyethylenimine

PMDTA: $N, N, N^{\prime}, N^{\prime \prime}, N^{\prime \prime}$-pentamethyldiethylenetriamine

R: Charge Ratio

RNA: Ribonucleic Acid

SDS-PAGE: Sodium Dodecyl Sulfate Polyacrylamide Gel Electrophoresis

SEC: Size Exclusion Chromatography

TAE: Tris-Acetate EDTA

TEM: Transmission Electron Microscopy

$\mathrm{T}_{\mathrm{t}}$ : Transition temperature 


\section{References}

(1) F. Bordi, L. Chronopoulou, C. Palocci, F. Bomboi, A. Di Martino, N. Cifani, B. Pompili, F. Ascenzioni, S. Sennato, Chitosan-DNA complexes: Effect of molecular parameters on the efficiency of delivery, Colloids Surf A 460 (2014) 184-190.

(2) M. Alatorre-Meda, P. Taboada, J. Sabin, B. Krajewska, L.M. Varela, J.R. Rodriguez, DNA-chitosan complexation: a dynamic light scattering study, Colloids Surf. A 339 (2009) $145-152$.

(3) C.Wu, J. Li, W. Wang, P.T. Hammond, Rationally Designed Polycationic Carriers for Potent Polymeric siRNA-Mediated Gene Silencing, ACS Nano, 12 (2018) 6504-6514.

(4) M. I. Giannotti, O. Esteban, M. Oliva, M. F. Garcia-Parajo, F. Sanz, pH-responsive polysaccharide-based polyelectrolyte complexes as nanocarriers for lysosomal delivery of therapeutic proteins, Biomacromolecules 12 (2011) 2524-2533.

(5) V. Vijayanathan, T. Thomas, T. J. Thomas, DNA nanoparticles and development of DNA delivery vehicles for gene therapy, Biochemistry 41 (2002) 14085-14094.

(6) R. Wolkowicz, G. P. Nolan, Gene therapy progress and prospects: Novel gene therapy approaches for AIDS, Gene Therapy 12 (2005) 467-476.

(7) P. Coimbra, P. Ferreira, P. Alves and M. H. Gil; 1. Polysaccharide-based polyelectrolyte complexes and polyelectrolyte multilayers for biomedical applications, Carbohydrates Applications in Medicine, 2014.

(8) T. Etrych, L. Leclercq, M. Boustta, M. Vert, Polyelectrolyte complex formation and stability when mixing polyanions and polycations in salted media: A model study related to the case of body fluids, Eur. J. Pharm. Sci. 25 (2005) 281-288.

(9) A. V. Kabanov, T. K. Bronich, V. A. Kabanov, K. Yu, A. Eisenberg, Soluble Stoichiometric Complexes from Poly(N-ethyl-4-vinylpyridinium) Cations and Poly(ethylene oxide)-block-polymethacrylate Anions, Macromolecules 29 (1996) 67976802.

(10)E. Tsuchida, Formation of polyelectrolyte complexes and their structures. J. Macromol. Sci. Part A 31 (1994) 1-15.

(11) J. Nakajima, Formation of polyelectrolyte complexes. J. Macromol. Sci. Part B 17(1980) 715-721. 
(12)E. Tsuchida, K. Abe, Interactions between macromolecules in solution and intermacromolecular complexes. Adv. Polym. Sci. 45 (1982) 1-119.

(13) J. Kötz, H. Köpke, G. Schmidt-Naake, O. Vogl, Polyanion- polycation complex formation as a function of the position of the functional groups, Polymer 37(1996) 2775-2781.

(14) S. Salatin, A. Yari Khosroushahi, Overviews on the cellular uptake mechanism of polysaccharide colloidal nanoparticles, J. Cell. Mol. Med. 21, (2017) 1668-1686

(15) S. Boddohi, N. Moore, P. A. Johnson, M. J. Kipper, Polysaccharide-Based Polyelectrolyte Complex Nanoparticles from Chitosan, Heparin, and Hyaluronan, Biomacromolecules 10 (2009) 1402-1409.

(16) P. A. Janmey, D. R. Slochower, Y. H. Wang, Q. Wen, A. Cebers, Polyelectrolyte properties of filamentous biopolymers and their consequences in biological fluids, Soft Matter. 10 (2014) 1439-1449.

(17) S. Lankalapalli, V. R. M. Kolopalli, Polyelectrolyte Complexes: A Review of their Applicability in Drug Delivery Technology, Indian J Pharm Sci. 71 (2009) 481-487.

(18) L. Jin, X. Zeng, M. Liu, Y. Deng, N. He, Current progress in gene delivery technology based on chemical methods and nano-carriers, Theranostics, 4 (2014) 240-255.

(19) B. Santos-Carballal, E. Fernández-Fernández, F. M. Goycoolea, Chitosan in Non-Viral Gene Delivery: Role of Structure, Characterization Methods, and Insights in Cancer and Rare Diseases Therapies, Polymers 444 (2018) 1-51.

(20)L.-L. Farrell, J. Pepin, C. Kucharski, X. Lin, Z. Xu, H. Uludag, A comparison of the effectiveness of cationic polymers poly-L-lysine (PLL) and polyethylenimine (PEI) for non-viral delivery of plasmid DNA to bone marrow stromal cells (BMSC), Eur. J. Pharm. Biopharm. 65 (2007) 388-397.

(21) S. Martino, I. Di Girolamo, R. Tiribuzi, F. D’Angelo, A. Datti, A. Orlacchio, Efficient siRNA Delivery by the Cationic Liposome DOTAP in Human Hematopoietic Stem Cells Differentiating into Dendritic Cells, J. Biomed. Biotechnol. 2009 (2009) 1-7.

(22) R. H. Mo, J. L. Zaro, W.-C. Shen, Comparison of cationic and amphipathic cell penetrating peptides for siRNA delivery and efficacy, Mol. Pharmaceutics 9 (2012) 299-309.

(23) Y. Liu, Z. Jia, L. Li, F. Chen, A genetically synthetic protein-based cationic polymer for siRNA delivery, Medical Hypotheses 76 (2011) 239-240. 
(24)W. Liang, J.K.W. Lam, Endosomal Escape Pathwaysisepifor Non-Viral Nucleic Acid Delivery Systems, Chapter 11, pp. 429-456, Molecular Regulation of Endocytosis, InTech, Rijeka, Croatia, 2012.

(25)C.-S. Cho, Design and Development of Degradable Polyethylenimines for Delivery of DNA and Small Interfering RNA: An Updated Review, ISRN Materials Science 2012 (2012) 1-24.

(26) J. R. Kramer, R. Petitdemange, L. Bataille, K. Bathany, A.-L. Wirotius, B. Garbay, T. J. Deming, E. Garanger, S. Lecommandoux, Quantitative Side-Chain Modifications of Methionine-Containing Elastin-Like Polypeptides as a Versatile Tool to Tune Their Properties, ACS Macro Lett. 4 (2015) 1283-1286.

(27)D. E. Meyer and A. Chilkoti, Quantification of the Effects of Chain Length and Concentration on the Thermal Behavior of Elastin-like Polypeptides, Biomacromolecules 5 (2004) 846-851.

(28) T. Kowalczyk, K. Hnatuszko-Konka, A. Gerszberg, A. K. Kononowicz, Elastin-like polypeptides as a promising family of genetically-engineered protein based polymers, World J. Microbiol. Biotechnol 30 (2014) 2141-2152.

(29) J. C. Rodríguez-Cabello, L. Martín, M. Alonso, F. J. Arias, A. M. Testera, "Recombinamers" as advanced materials for the post-oil age, Polymer 50 (2009) 5159-5169.

(30) J. R. McDaniel, D. C. Radford, A. Chilkoti, A unified model for de novo design of elastinlike polypeptides with tunable inverse transition temperatures, Biomacromolecules 14 (2013) 2866-2872.

(31) J. A. MacKay, D. J. Callahan, K. N. FitzGerald, A. Chilkoti, Quantitative Model of the Phase Behavior of Recombinant pH-Responsive Elastin-Like Polypeptides, Biomacromolecules 11 (2010) 2873-2879.

(32)D. W. Urry, C.-H. Luan, T. M. Parker, D. C. Gowda, K. U. Prasad, M. C. Reid, A. Safavy, Temperature of polypeptide inverse temperature transition depends on mean residue hydrophobicity, J. Am. Chem. Soc. 113 (1991) 4346-4348.

(33) M. R. Dreher, A. Simnick, K. Fischer, R. J. Smith, A. Patel, M. Schmidt, A. Chilkoti, Temperature Triggered Self-Assembly of Polypeptides into Multivalent Spherical Micelles, J. Am. Chem. Soc. 130 (2008) 687-694. 
(34) W. Kim, J. Thevenot, E. Ibarboure, S. Lecommandoux, E. L. Chaikof, Self-assembly of thermally responsive amphiphilic diblock copolypeptides into spherical micellar nanoparticles, Angew. Chem., Int. Ed. Engl. 49 (2010) 4257-4260.

(35)R. E. Sallach, M. Wei, N. Biswas, V. P. Conticello, S. Lecommandoux, R. A. Dluhy, E. L. Chaikof, Micelle density regulated by a reversible switch of protein secondary structure, J. Am. Chem. Soc. 128 (2006) 12014-12019.

(36) J. C. M. Van Hest, D. A. Tirrell, Protein-based materials, toward a new level of structural control, Chem. Commun. (2001), 1897- 1904.

(37) J. L. Frandsen, H. Ghandehari, Recombinant protein-based polymers for advanced drug delivery Chem. Soc. Rev. 41 (2012) 2696-2706.

(38) I. Massodi, D. Raucher, A thermally responsive Tat-elastin-like polypeptide fusion protein induces membrane leakage, apoptosis, and cell death in human breast cancer cells, J. Drug Target 15 (2007) 611-622.

(39) A. J. Simnick, D. W. Lim, D. Chow, A. Chilkoti, Biomedical and biotechnological applications of elastin-like polypeptides, Polym. Rev. 47 (2007) 121-154.

(40) M. R. Dreher, D. Raucher, N. Balu, O.M. Colvin, S.M. Ludeman, A. Chilkoti, Evaluation of an elastin-like polypeptide-doxorubicin conjugate for cancer therapy, J. Controlled Release 91 (2003) 31-43.

(41) S.R. MacEwan, A. Chilkoti, Applications of elastin-like polypeptides in drug delivery, J. Control Release, 190 (2014) 314-330.

(42) R. Saxena, M. Nanjan, Elastin-like polypeptides and their applications in anticancer drug delivery systems: a review, J. Drug Delivery 22 (2015) 156-167.

(43) W. Hassouneh, S. R. MacEwan, A. Chilkoti, Fusions of elastin-like polypeptides to pharmaceutical proteins, Methods Enzymol. 502 (2012) 215-237.

(44) S. Fluegel, J. Buehler, K. Fischer, J.R. McDaniel, A. Chilkoti, M. Schmidt, Self-assembly of monodisperse oligonucleotide-elastin block copolymers into stars and compound micelles, Chemistry 17 (2011) 5503-5506.

(45)E. G. Gharakhanian, T. J. Deming, Versatile synthesis of stable, functional polypeptides via reaction with epoxides, Biomacromolecules 16 (2015) 1802-1806. 
(46)R. Petitdemange, E. Garanger, L. Bataille, W. Dieryck, K. Bathany, B. Garbay, T.J. Deming, S. Lecommandoux, Selective Tuning of Elastin-like Polypeptide Properties via Methionine Oxidation, Biomacromolecules 18 (2017) 544-550.

(47) J. R. McDaniel, J. Bhattacharyya, K. B. Vargo, W. Hassouneh, D. Hammer, A. Chilkoti, Self-assembly of thermally responsive nanoparticles of a genetically encoded peptide polymer by drug conjugation, Angew. Chem., Int. Ed. Engl. 52 (2013) 1683-1687.

(48) T.-H. Howard Chen, Y. Bae, D. Y. Furgeson, Intelligent Biosynthetic Nanobiomaterials (IBNs) for Hyperthermic Gene Delivery, Pharm. Res. 25(3) (2008) 683-691.

(49) C. H. Lee, R. S. J. Ingrole, and Harvinder Singh Gill, Generation of induced pluripotent stem cells using elastin like polypeptides as a non-viral gene delivery system, BBAMolecular Basis of Disease (2019) in press.

(50) B. C. Dash, S. Mahor,O. Carroll, A. Mathew, W. Wang, K.A. Woodhouse, A. Pandit, Tunable elastin-like polypeptide hollow sphere as a high payload and controlled delivery gene depot, J. Control. Release 152 (2011) 382-392.

(51) B. C. Dash, D. Thomas, M. Monaghan, O. Carroll, X. Chen, K. Woodhouse, T. O'Brien, A. Pandit, An injectable elastin-based gene delivery platform for dose- dependent modulation of angiogenesis and inflammation for critical limb ischemia, Biomaterials 65 (2015) 126139.

(52) J.-S. Kim, H.S. Chu, K.I. Park, J.-I. Won, J.-H. Jang, Elastin-like polypeptide matrices for enhancing adeno-associated virus-mediated gene delivery to human neural stem cells, Gene Therapy 19 (2012) 329-337.

(53)K. Trabbic-Carlson, L. A. Setton, A. Chilkoti, Swelling and Mechanical Behaviors of Chemically Cross-Linked Hydrogels of Elastin-like Polypeptides, Biomacromolecules 4 (2003) 572-580.

(54)D. W. Lim, D. L. Nettles, L. A. Setton, A. Chilkoti, Rapid Cross-Linking of Elastin-like Polypeptides with (Hydroxymethyl)phosphines in Aqueous Solution, Biomacromolecules 8 (2007) 1463-1470.

(55) R. Petitdemange, E. Garanger, L. Bataille, K. Bathany, B. Garbay, T. J. Deming, S. Lecommandoux, Tuning Thermoresponsive Properties of Cationic Elastin-like Polypeptides by Varying Counterions and Side-Chains, Bioconjugate Chem. 28 (2017) 1403-1412. 
(56)E. E. Fletcher, D. Yan, A. A. Kosiba, Y. Zhou, H. Shi, Biotechnological applications of elastin-like polypeptides and the inverse transition cycle in the pharmaceutical industry, Protein Expr. Purif. 153 (2019) 114-120.

(57)L. Bataille, W. Dieryck, A. Hocquellet, C. Cabanne, K. Bathany, S. Lecommandoux, B. Garbay, E. Garanger, Recombinant production and purification of short hydrophobic Elastin-like polypeptides with low transition temperatures, Protein Expr. Purif. 121 (2016) 81-87.

(58) S. Lin, X. Yang, S. Jia, A. M. Weeks, M. Hornsby, P. S. Lee, R. V. Nichiporuk, A. T. Iavarone, J. A. Wells, F. Dean Toste, C. J. Chang, Redox-based reagents for chemoselective methionine bioconjugation, Science 355 (2017) 597-602.

(59)L. M. Bravo-Anaya, F. Pignon, F. A. Soltero and M. Rinaudo, Conformation and Rheological Properties of Calf-Thymus DNA in Solution, Polymers 8 (2016) 51-69.

(60) N.-T. Huynh, Y.-S. Jeon, M. Zrinyi, J.-H. Kim, Preparation of 'click' hydrogels from polyaspartamide derivatives, Polym Int. 62 (2013) 266-272.

(61) J. Cavanagh, W.J. Fairbrother, A.G. Palmer, N.J. Skelton, Protein NMR Spectroscopy: Principles and Practice, Academic Press, San Diego, CA, 1996.

(62)K. Wüthrich, NMR of Proteins and Nucleic Acids, John Wiley \& Sons,, New York, 1986.

(63) M. Mende, H.M. Buchhammer, S. Schwarz, G. Petzold, W. Jaeger, The stability of polyelectrolyte complex systems of PDADMAC with different polyanions, Macromol Symp. 211 (2004) 121-133.

(64) A. D. Kulkarni, Y. H. Vanjari, K. H. Sancheti, Harun M. Patel, V. S. Belgamwar, S. J. Surana, C. V. Pardeshi, Polyelectrolyte complexes: mechanisms, critical experimental aspects, and applications, Artificial Cells, Nanomedicine and Biotechnology, 44 (2016) $1615-1625$.

(65) C. Schatz, J. Lucas, C. Viton, A. Domard, C. Pichot, T. Delair, Formation and properties of positively charged colloids based on polyelectrolyte complexes of biopolymers, Langmuir, 20 (2004) 7766-7778.

(66)F. Yang, W. Wu, S. Chen, W. Gan, The ionic strength dependent zeta potential at the surface of hexadecane droplets in water and the corresponding interfacial adsorption of surfactants, Soft Matter 13(3) (2017) 638-646. 
(67)L. Xu, F. Mallamace, Z. Yan, F. W. Starr, S. V. Buldyrev, H. E. Stanley, Appearance of a fractional Stokes-Einstein relation in water and a structural interpretation of its onset, Nature Physics 5 (2009) 565.

(68) A. Pullman, J. Jortner, Molecular basis of specificity in nucleic acid-drug interactions, Proceedings of the Twenty-Third Jerusalem Symposium on Quantum Chemistry and Biochemistry Held in Jerusalem, Israel, 1990.

(69) V. V. Rostovtsev, L. G. Green, V. V. Fokin, K. B. Sharpless, A stepwise huisgen cycloaddition process: copper (I)-catalyzed regioselective "ligation" of azides and terminal alkynes, Angew. Chem. Int. Ed. 41 (2002) 2596-2599.

(70) L. Liang, D. Astruc, The copper (I)-catalyzed alkyne-azide cycloaddition (CuAAC)“click" reaction and its applications. An overview, Coord Chem. Rev. 255 (2011) 2933-2945.

(71) J. R. Kramer, T. J. Deming, Reversible chemoselective tagging and functionalization of methionine containing peptides, Chem. Commun. 49 (2013) 5144-5146.

(72) T.S. Work, E. Work, Laboratory Techniques in Biochemistry and Molecular Biology, Chapter 7: Essentials of gel electrophoresis, Volume 4, 302-358, 1976.

(73) A. Striegel, W.W. Yau, J.J. Kirkland, D.D. Bly, Modern Size-Exclusion Liquid Chromatography: Practice of Gel Permeation and Gel Filtration Chromatography, 2nd Edition, John Wiley \& Sons, New Jersey, 2009.

(74) J. Brugnerotto, J. Desbrières, G. Roberts, M. Rinaudo, Characterization of chitosan by steric exclusion chromatography, Polymer 42 (2001) 9921-9927.

(75)L. M. Bravo-Anaya, J. F. A. Soltero, M. Rinaudo, DNA/chitosan electrostatic complex, Int. J. of Biol. Macromolecules 88 (2016) 345-353.

(76) A.C. Engler, D.K. Bonner, H.G. Bus, E.Y. Cheung, O.T. Hammond The synthetic tuning of clickable $\mathrm{pH}$ responsive cationic polypeptides and block copolypeptides, Soft Matter 7 (2011) 5627-5637.

(77)Q. Gan, T. Wang, C. Cochrane, P. McCarron, Modulation of surface charge, particle size and morphological properties of chitosan-TPP nanoparticles intended for gene delivery, Colloids Surf., B 44 (2005) 65-73.

(78) J.-P. Clamme, G. Krishnamoorthy, Y. Mély, Intracellular dynamics of the gene delivery vehicle polyethylenimine during transfection: investigation by two-photon fluorescence correlation spectroscopy, Biochimica et Biophysica Acta 1617 (2003) 52-61. 
(79) Y. Liu, Z. Jia, L. Li, F. Chen, A genetically synthetic protein-based cationic polymer for siRNA delivery, Medical Hypotheses 76 (2011) 239-240.

(80) A. Sillero, J. Maireles Ribeiro, Isoelectric Points of Proteins: Theoretical Determination, Anal. Biochem. 179 (1989) 319-325.

(81)A. Tsortos, G. Papadakis, E. Gizeli, The intrinsic viscosity of linear DNA, Biopolymers 95 (2011) 824-832.

(82) G. S. Manning, Molecular theory of polyelectrolyte solutions with applications to electrostatic properties of polynucleotides, Q. Rev. Biophys. 11 (1978) 179-246.

(83)D. Matulis, I. Rouzina, V. A. Bloomfield, Thermodynamics of DNA binding and condensation: isothermal titration calorimetry and electrostatic mechanism, J. Mol. Biol. 296 (2000) 1053-1063.

(84) M. Alatorre-Meda, P. Taboada, F. Hartl, T. Wagner, M. Freis, J. R. Rodríguez, The influence of chitosan valence on the complexation and transfection of DNA: the weaker the DNA-chitosan binding the higher the transfection efficiency, Colloids Surf. B 82 (2011) 54-62.

(85) M. Alatorre-Meda, P. Taboada, B. Krajewska, M. Willemeit, A. Deml, R. Klösel, J.R. Rodríguez, DNA-poly(diallyldimethylammonium chloride) complexation and transfection efficiency, J. Phys. Chem. B 114 (2010) 9356-9366.

(86) K. Itaka, K. Yamauchi, A. Harada, K. Nakamura, H. Kawaguchi, K. Kataoka, Polyion complex micelles from plasmid DNA and poly(ethylene glycol)-poly(l-lysine) block copolymer as serum-tolerable polyplex system: physicochemical properties of micelles relevant to gene transfection efficiency, Biomaterials 24 (2003) 4495-4506.

(87) M. X. Tang, F. C. Szoka, The influence of polymer structure on the interactions of cationic polymers with DNA and morphology of the resulting complexes, Gene Ther. 4 (1997) 823832.

(88) Y. Guping, T. Guping, Yanjie, A New Biodegradable Poly-Amino Acid: $\alpha, \beta-P o l y[(N-$ Hydroxypropyl/Aminoethyl)-DL-Aspartamide-co-L-Lysine], A Potential Nonviral Vector for Gene Delivery, Drug Delivery 12 (2005) 89-96.

(89) C. W. Pouton, P. Lucas, B. J. Thomas, A. N. Uduehi, D. A. Milroy, S. H. Moss, Polycation-DNA complexes for gene delivery: a comparison of the biopharmaceutical 
properties of cationic polypeptides and cationic lipids, J. Control. Release 53 (1998) 289299.

(90) M. X. Tang, F. C. Szoka, The influence of polymer structure on the interactions of cationic polymers with DNA and morphology of the resulting complexes, Gene Ther. 4 (1997) 823832.

(91)F. Amaduzzi, F. Bomboi, A. Bonincontro, F. Bordi, S. Casciardi, L. Chronopoulou, M. Diociaiuti, F. Mura, C. Palocci, S. Sennato, Chitosan-DNA complexes: charge inversion and DNA condensation, Colloid Surf. B 114 (2014) 1-10.

(92) S. Sennato, F. Bordi, C. Cametti, M. Diociaiuti, P. Malaspina, Charge patch attraction and reentrant condensation in DNA-liposome complexes, Biochimica et Biophysica Acta 1714 (2005) $11-24$.

(93) D. Fischer, Y. Li, B. Ahlemeyer, J. Krieglstein, T. Kissel, In vitro cytotoxicity testing of polycations: influence of polymer structure on cell viability and hemolysis, Biomaterials 24 (2003) 1121-1131.

(94)A. C. Hunter, Molecular hurdles in polyfectin design and mechanistic background to polycation induced cytotoxicity, Adv. Drug Delivery Rev. 58 (2006) 1523-1531.

(95) K. Miyata, N. Nishiyama, K. Kataoka, Rational design of smart supramolecular assemblies for gene delivery: chemical challenges in the creation of artificial viruses, Chem. Soc. Rev., 41 (2012) 2562-2574.

(96) H. Katas, H. O. Alpar, Development and characterization of chitosan nanoparticles for siRNA delivery, J. Control. Release 115 (2006) 216-225.

(97) T. Delair, Colloidal polyelectrolyte complexes of chitosan and dextran sulfate towards versatile nanocarriers of bioactive molecules, Eur. J. Pharm. Biopharm. 78 (2011) 10-18.

(98)D. Wu, T. Delair, Stabilization of chitosan/hyaluronan colloidal polyelectrolyte complexes in physiological conditions, Carbohydr. Polym., 119 (2015) 149-158.

(99) C. Schatz, A. Domard, C. Viton, C. Pichot, T. Delair, Versatile and efficient formation of colloids of biopolymer-based polyelectrolyte complexes, Biomacromol. 5 (2004) 18821892.

(100) H.V. Sæther, H.K. Holme, G. Maurstad, O. Smidsrod, B.T. Stokke, Polyelectrolyte complex formation using alginate and chitosan, Carbohydr Polym. 74 (2008) 813-821. 
S. Danielsen, G. Maurstad, B.T. Stokke, DNA-Polycation complexation and polyplex stability in the presence of competing polyanions, Biopolymers 77 (2005) 86-97.

(102) M.M. Rahman, H. Yasuda, S. Katsura, Akira Mizuno, Covalent binding and conformational change of pUC19 DNA by rhodium (II) metal complex, J.Biomol. Struct. Dyn., 24 (2007) 553-560.

(103) G. Witz, A. Stasiak, DNA supercoiling and its role in DNA decatenation and unknotting, Nucleic Acids Res., 38 (2010) 2119-2133.

(104) T. Schmatko, P. Muller, M. Maaloum, Surface charge effects on the 2D conformation of supercoiled DNA, Soft Matter, 10 (2014) 2520-2529.

(105) E. Wagner, M. Cotten, R. Foisner, M.L. Birnstiel, Transferrin polycation DNA complexes - the effect of polycations on the structure of the complex and DNA delivery to cells, Proc. Natl. Acad. Sci. U.S.A. 88 (1991) 4255-4259.

(106) M. Tsuboi, K. Matsuo, Interaction of poly-L-Lysine and nucleic acids, J. Mol. Biol. 15 (1966) 256-267.

(107) V.A. Kabanov, A.B. Zezin, Soluble interpolymeric complexes as a new class of synthetic polyelectrolytes, Pure Appl. Chem. 56 (3) (1984) 343-354.

(108) R. Nasanit, P. Iqbal, M. Soliman, N. Spencer, S. Allen, M. C. Davies, S.S. Briggs, L.W. Seymour, J.A. Preece, C. Alexander, Combination dual responsive polypeptide vectors for enhanced gene delivery, Molecular BioSystems 4 (2008) 697-780.

(109) M. de Los Milagros Bassani Molinas, C. Beer, F. Hesse, M. Wirth, R. Wagner, Optimizing the transient transfection process of HEK-293 suspension cells for protein production by nucleotide ratio monitoring, Cytotechnology 66 (2014) 493-514. 


\section{Figure captions}

Scheme 1. A) Chemical structure of the native ELP. B) Simplified reaction scheme of the synthesis of ELP(-CCH) by chemoselective thioalkylation of ELP with glycidyl propargyl ether and of $\operatorname{ELP}\left(-\mathrm{NH}_{2}\right)$ and $\operatorname{ELP}\left(-\mathrm{NHCH}_{3}\right)$ by $\mathrm{CuAAC}$.

Figure 1. a) SDS-PAGE (4-20\%) analysis of ELP, ELP(-CCH), ELP(-NH $\left.\mathrm{NH}_{2}\right)$ and ELP($\mathrm{NHCH}_{3}$ ), the protein bands were revealed by coloration with colloidal coomassie $\left(\right.$ InstantBlue ${ }^{\mathrm{TM}}$ ) b) Size exclusion chromatograms in AcOH/Ammonium Acetate/ACN of ELP (black), ELP(-CCH) (orange), ELP(- $\left.\mathrm{NH}_{2}\right)$ (purple) and $\operatorname{ELP}\left(-\mathrm{NHCH}_{3}\right)$ (pink) using a RI detector, c) $\zeta$-potential and potentiometric titration of $100 \mu \mathrm{M}$ ELPs samples (dissolved in $\mathrm{HCl}$ ) with $0.01 \mathrm{~N} \mathrm{NaOH}$, d) Absorbance (\%) at $600 \mathrm{~nm}$ as a function of temperature of $100 \mu \mathrm{M}$ solutions of ELP in Tris $10 \mathrm{mM}$ buffer. SDS-Page and SEC experiments were performed at least three times. $\zeta$-potential experiments were performed in duplicate.

Figure 2. a) Electrical conductivity $(\kappa)$ dependence on the ratio $\mathrm{S} / \mathrm{P}$ during $\mathrm{ELP}(-\mathrm{CCH})$ progressive addition to CT-DNA solution. b) Electrical conductivity ( $\kappa)$ dependence on the ratio $(\mathrm{N}+\mathrm{S}) / \mathrm{P}$ during $\mathrm{CT}-\mathrm{DNA} / \mathrm{ELP}\left(-\mathrm{NH}_{2}\right)$ complex formation (slow dropwise mixing method). Temperature measurement: $25^{\circ} \mathrm{C} . \mathrm{C}_{\mathrm{DNA}}=0.0 .1 \mathrm{~g} / \mathrm{L}$ in water at $\mathrm{pH}=6.5, \mathrm{C}_{\mathrm{ELP}(-\mathrm{CCH})}=2 \mathrm{~g} / \mathrm{L}$ and $\mathrm{C}_{\mathrm{ELP}(-\mathrm{NH} 2)}=2 \mathrm{~g} / \mathrm{L}$, both prepared at $\mathrm{pH}=6.0$. Experiments were performed in duplicate.

Figure 3. a) $\zeta$-potential as a function of $\mathrm{S} / \mathrm{P}$ ratio during $\mathrm{CT}-\mathrm{DNA} / \mathrm{ELP}(-\mathrm{CCH})$ interactions. b) $\zeta$-potential as a function of $(\mathrm{N}+\mathrm{S}) / \mathrm{P}$ ratio during CT-DNA/ELP(-NH$)$ and CT-DNA/ELP ($\mathrm{NHCH}_{3}$ ) complex formation (slow dropwise mixing method). Temperature measurement: 25 ${ }^{\circ} \mathrm{C} . \mathrm{C}_{\mathrm{DNA}}=0.01 \mathrm{~g} / \mathrm{L}$ in water at $\mathrm{pH}=6.5, \mathrm{C}_{\mathrm{ELP}(-\mathrm{CCH})}=0.2 \mathrm{~g} / \mathrm{L}, \mathrm{C}_{\mathrm{ELP}(-\mathrm{NH} 2)}=0.2 \mathrm{~g} / \mathrm{L}$ and $\mathrm{C}_{\mathrm{ELP}(-}$ $\mathrm{NHCH}_{3}=0.2 \mathrm{~g} / \mathrm{L}$ all of them prepared at $\mathrm{pH}=6.0$. $\zeta$-potential experiments were performed in triplicate.

Figure 4. a) $\zeta$-potential and b) Hydrodynamic diameter $\left(D_{H}\right)$ as a function of $(N+S) / P$ ratio during pUC19 plasmid/ELP(- $\left.\mathrm{NH}_{2}\right)$ complex formation. Conventional slow dropwise mixing of $\mathrm{ELP}\left(-\mathrm{NH}_{2}\right)$ to a DNA solution was used for $\zeta$-potential measurements. c) Intensity distribution, correlation function and d) AFM image of pUC19 plasmid/ELP(- $\left.\mathrm{NH}_{2}\right)$ complex prepared at a charge ratio of $(\mathrm{N}+\mathrm{S}) / \mathrm{P}=5$ through rapid one-shot mixing of cationic ELPs to anionic DNA. Temperature measurement: $37^{\circ} \mathrm{C} . \mathrm{C}_{\mathrm{pUC19}}=0.005 \mathrm{~g} / \mathrm{L}$ prepared in Tris $10 \mathrm{mM}$ buffer at a $\mathrm{pH}=7.4, \mathrm{C}_{\mathrm{ELP}(-\mathrm{NH} 2)}=0.2 \mathrm{~g} / \mathrm{L}$ prepared at $\mathrm{pH}=6.0$. DLS and $\zeta$-potential experiments were performed in triplicate.

Figure 5. a) Intensity distribution as a function of size, and b) and c) TEM images of pUC19 plasmid/ELP $\left(-\mathrm{NH}_{2}\right)$ complex prepared at a charge ratio of $(\mathrm{N}+\mathrm{S}) / \mathrm{P}=0.5$. d) Intensity distribution as a function of size, and e) and f) TEM images of pUC19 plasmid/ELP(- $\left.\mathrm{NH}_{2}\right)$ complex prepared at a charge ratio of $(\mathrm{N}+\mathrm{S}) / \mathrm{P}=3.0 . \mathrm{C}_{\mathrm{pUC} 19}=0.005 \mathrm{~g} / \mathrm{L}$ prepared in Tris $10 \mathrm{mM}$ buffer at 
a $\mathrm{pH}=7.4, \mathrm{C}_{\mathrm{ELP}(-\mathrm{NH} 2)}=0.2 \mathrm{~g} / \mathrm{L}$ prepared at $\mathrm{pH}=6.0 . \mathrm{pUC} 19$ plasmid/ELP(-NH $\left.\mathrm{N}_{2}\right)$ complexes were prepared through rapid one-shot mixing of cationic ELPs to anionic DNA. DLS experiments were performed in triplicate.

Figure 6. AFM images of a) pUC19 plasmid and pUC19/ELP(- $\left.\mathrm{NH}_{2}\right)$ complexes prepared at the following charge ratios $(\mathrm{R}=(\mathrm{N}+\mathrm{S}) / \mathrm{P}): \mathrm{b}) \mathrm{R}=0.5$, c) $\mathrm{R}=0.8$, d) $\mathrm{R}=3$, e) $\mathrm{R}=5$ and f) $\mathrm{R}=10 . \mathrm{C}_{\mathrm{pUC} 19}=$ $0.005 \mathrm{~g} / \mathrm{L}$ prepared in Tris $10 \mathrm{mM}$ buffer at a $\mathrm{pH}=7.4, \mathrm{C}_{\mathrm{ELP}}\left(-\mathrm{NH}_{2}\right)=0.2 \mathrm{~g} / \mathrm{L}$ prepared at $\mathrm{pH}=$ 6.0. pUC19 plasmid/ELP(- $\left.\mathrm{NH}_{2}\right)$ complexes were prepared through rapid one-shot mixing of cationic ELPs to anionic DNA.

Figure 7. Electrophoresis gel assays showing the effect of a) ELP-to-plasmid amounts (mass/mass), b) and c) S/P charge ratio for $\operatorname{ELP}(-\mathrm{CCH}), \mathrm{d})(\mathrm{N}+\mathrm{S}) / \mathrm{P}$ charge ratio for $\operatorname{ELP}\left(-\mathrm{NH}_{2}\right)$ and e) $(\mathrm{N}+\mathrm{S}) / \mathrm{P}$ charge ratio for $\mathrm{ELP}\left(-\mathrm{NHCH}_{3}\right)$ on the electrophoretic mobility of linearized pUC19 plasmid (BamHI digested). M represents the molecular weights of the marker (SmartLadder MW-1700-10 Eurogentec). $\mathrm{C}_{\mathrm{puC} 19}=0.095 \mathrm{~g} / \mathrm{L}$ prepared in Tris $10 \mathrm{mM}$ buffer at a $\mathrm{pH}=7.4, \mathrm{C}_{\mathrm{ELP}(-\mathrm{NH} 2)}=0.2 \mathrm{~g} / \mathrm{L}$ prepared at $\mathrm{pH}=6.0$.

Figure 8. Electrophoresis gel assays showing the effect of charge ratio, i.e. $\mathrm{S} / \mathrm{P}$ or $(\mathrm{N}+\mathrm{S}) / \mathrm{P}$ on the electrophoretic mobility of linearized pUC19 plasmid: a) ELP(-CCH) and b) ELP(- $\left.-\mathrm{NH}_{2}\right)$ in presence of $154 \mathrm{mM} \mathrm{NaCl}$ and c) $\mathrm{ELP}\left(-\mathrm{NH}_{2}\right)$ in presence of $358 \mathrm{mM} \mathrm{NaCl}$. Electrophoresis gel assays showing the effect of d) $\mathrm{NaCl}$ concentration and e) SDS (\%) on DNA-binding properties of $\operatorname{ELP}\left(-\mathrm{NH}_{2}\right)$ at a constant $(\mathrm{N}+\mathrm{S}) / \mathrm{P}$ ratio of 1.3. M represents the molecular weights of the marker (SmartLadder MW-1700-10 Eurogentec). $\mathrm{C}_{\mathrm{pUC} 19}=0.095 \mathrm{~g} / \mathrm{L}$ prepared in Tris $10 \mathrm{mM}$ buffer at a $\mathrm{pH}=7.4, \mathrm{C}_{\mathrm{ELP}(-\mathrm{NH} 2)}=0.2 \mathrm{~g} / \mathrm{L}$ prepared at $\mathrm{pH}=6.0$. 


\section{Scheme 1}

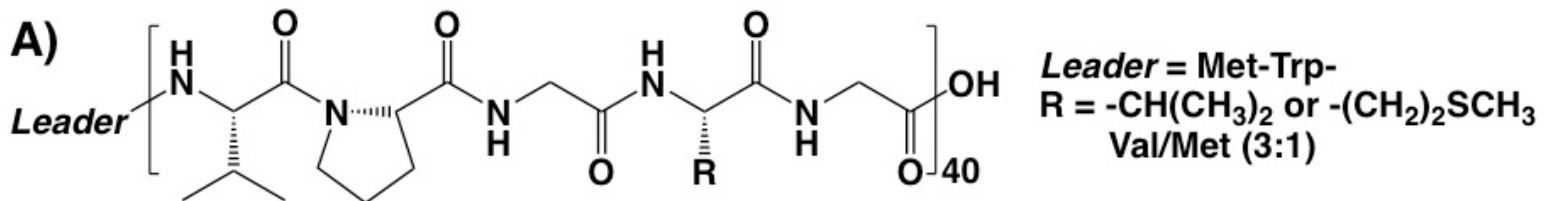

B)
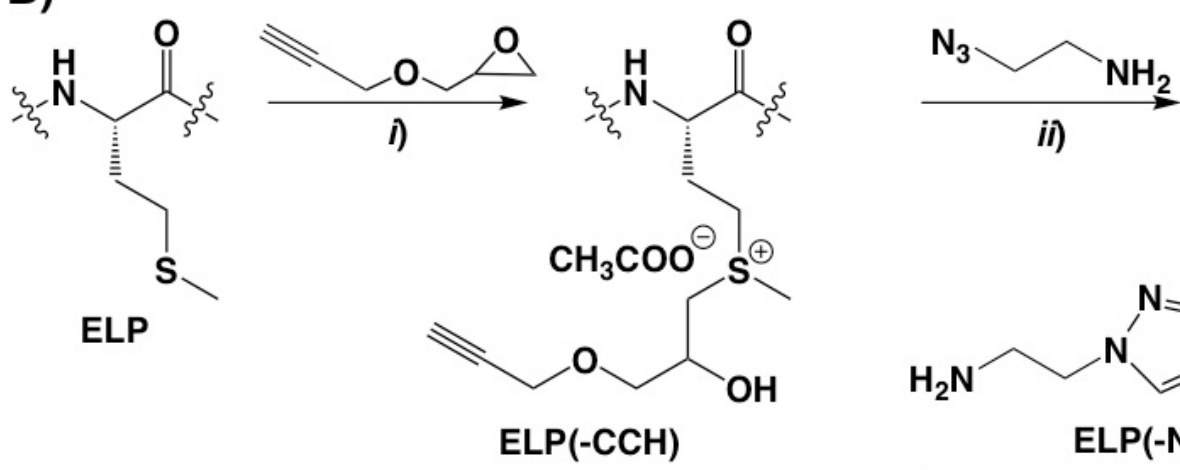

i)<smiles>CCC[Sb](C)(CC(O)COCc1cn(CCN)nn1)C[S+](C)(N)OC(C)=O</smiles>

i) AcOH/ HFIP (9:1)

RT, $\mathrm{N}_{2}, 48 \mathrm{hrs}$

ii) $\mathrm{Cu}(\mathrm{II}) \mathrm{SO}_{4}, \mathrm{NaAsc}, \mathrm{PMDTA}$

$\mathrm{RT}, \mathrm{N}_{2}, 72$ hrs

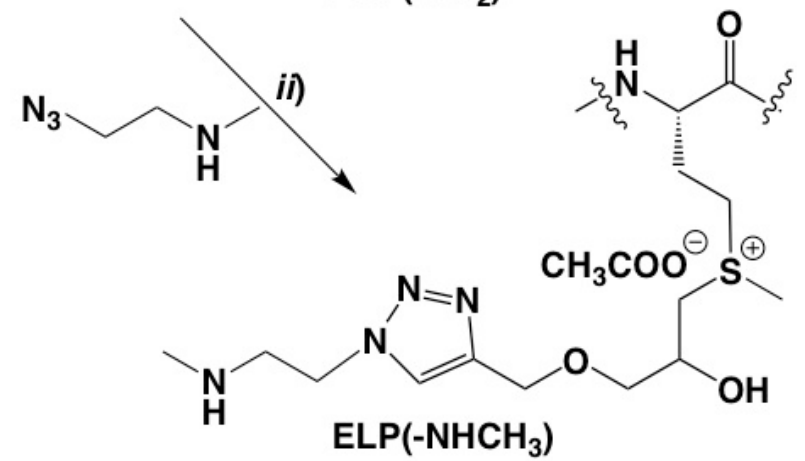


Figure 1
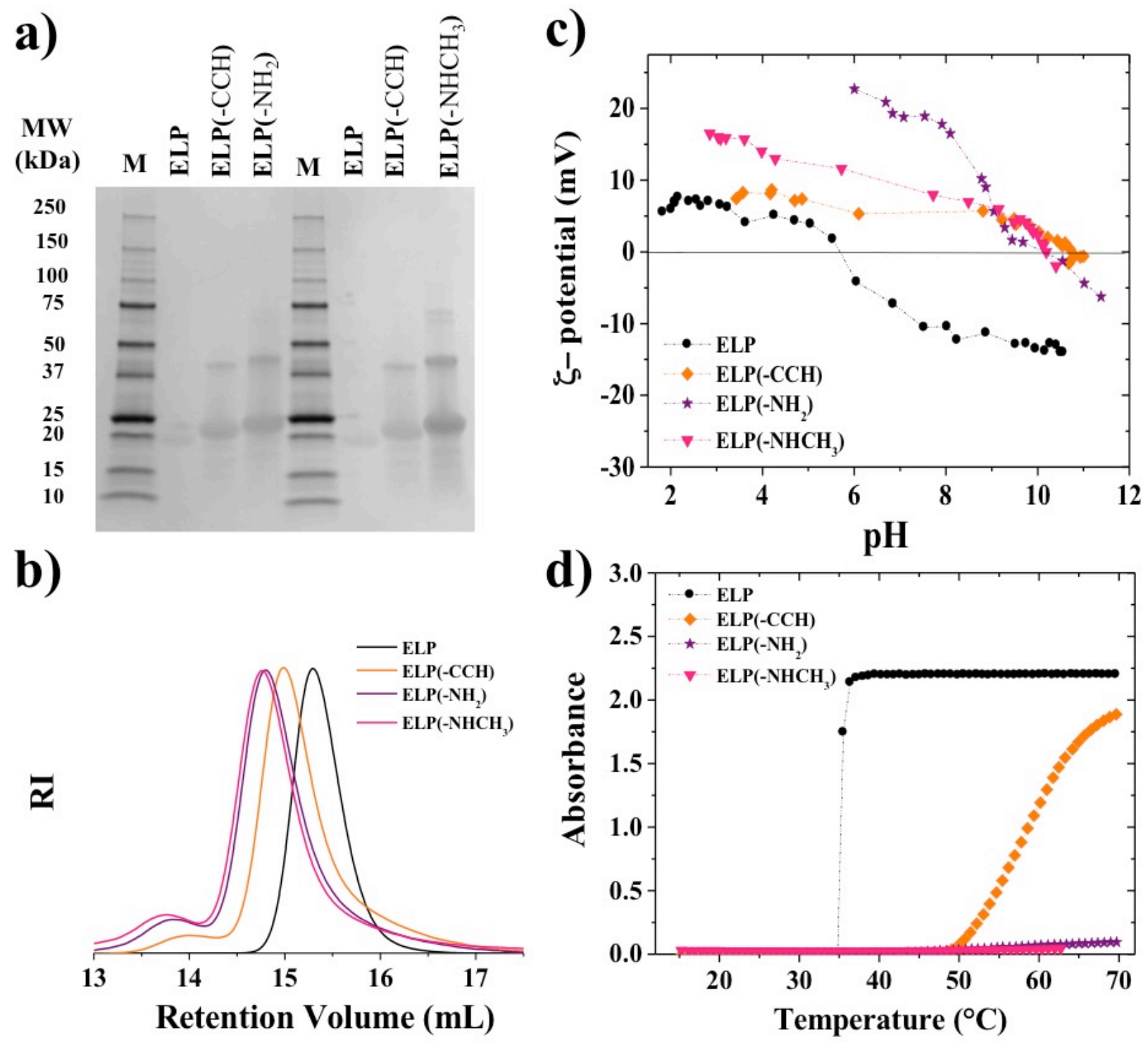
Figure 2

a)
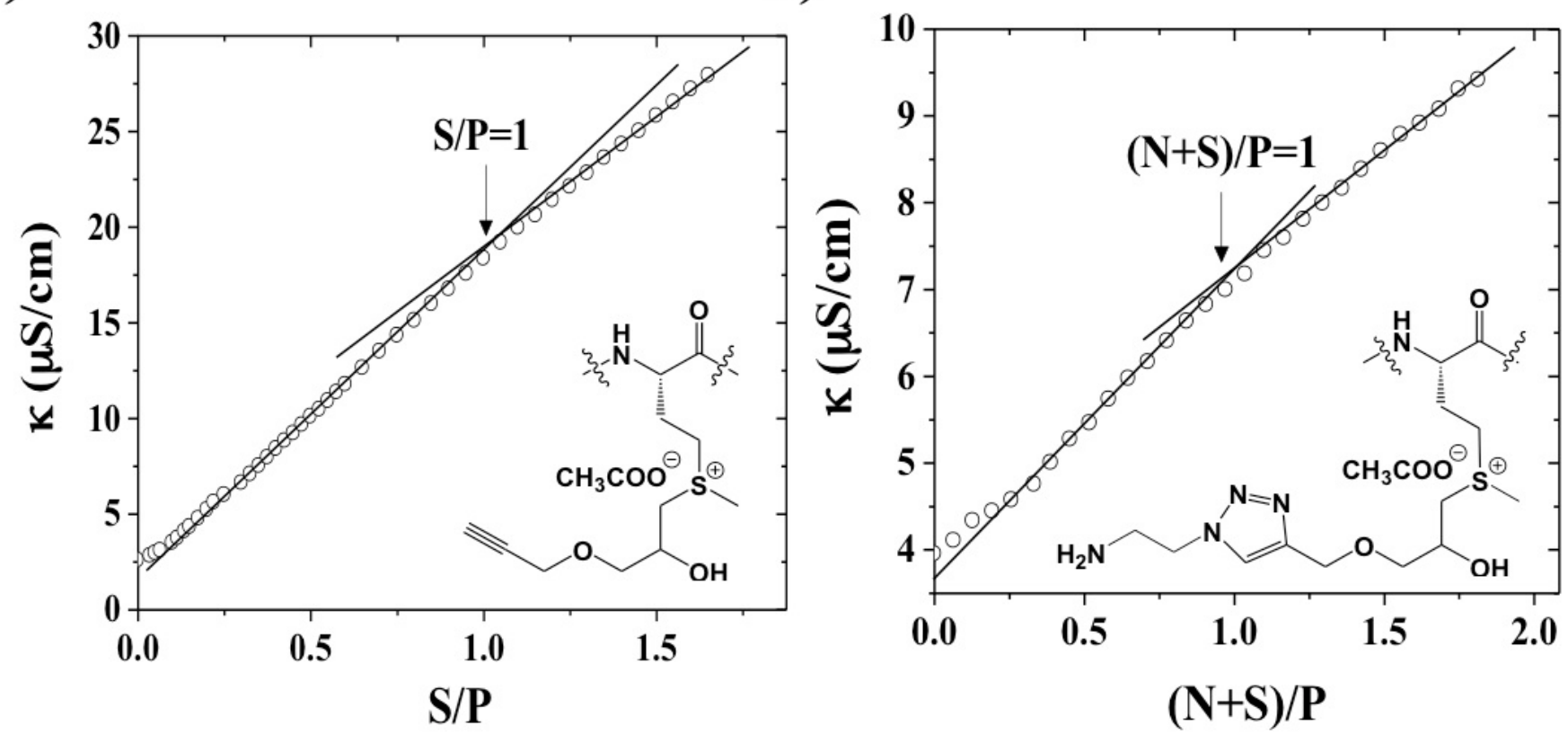


\section{Figure 3}

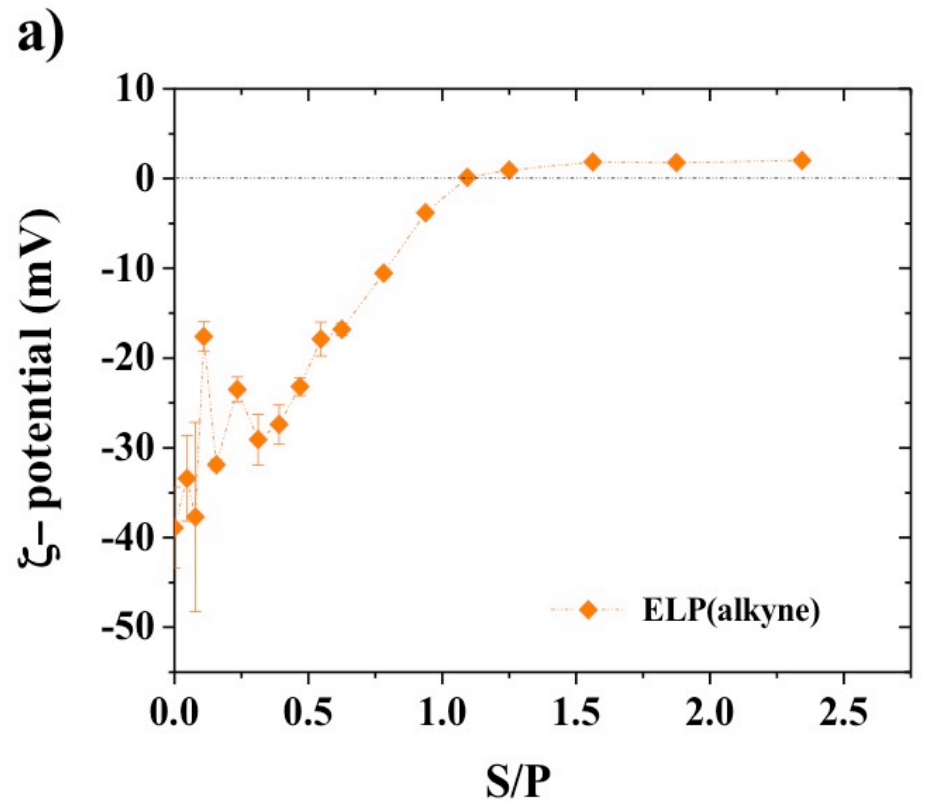

b)

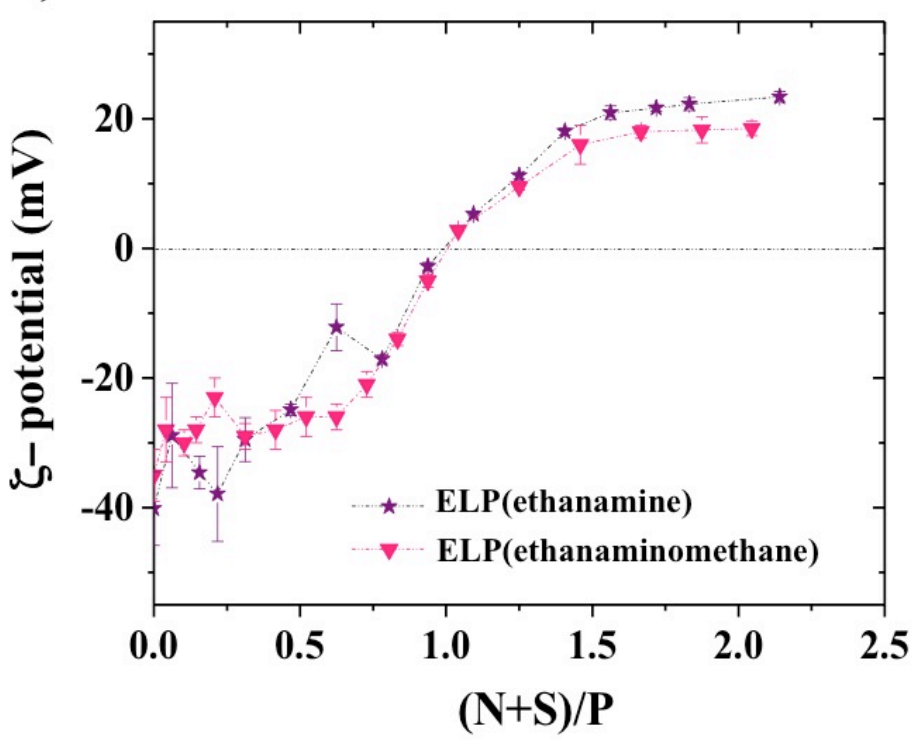


Figure 4

a)

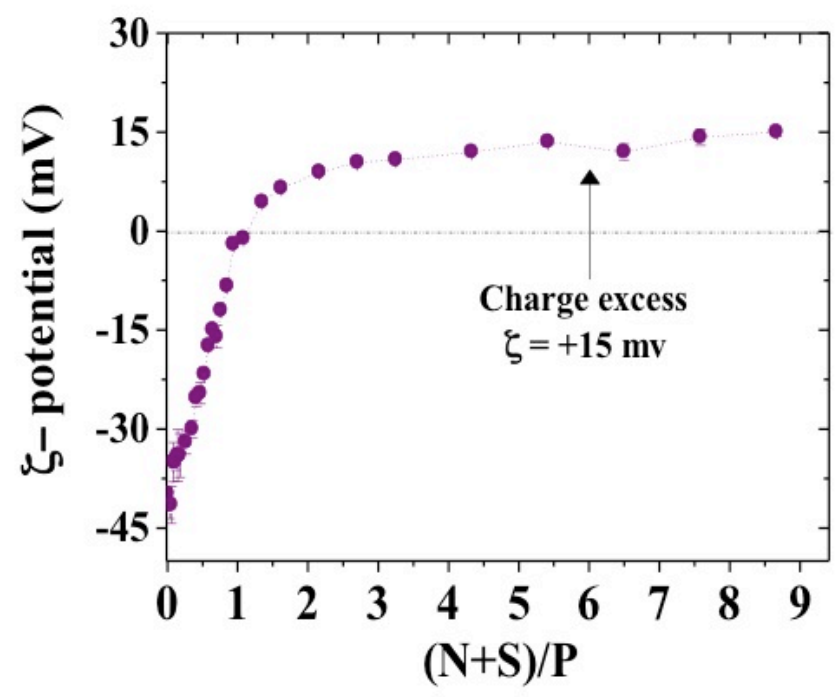

c)

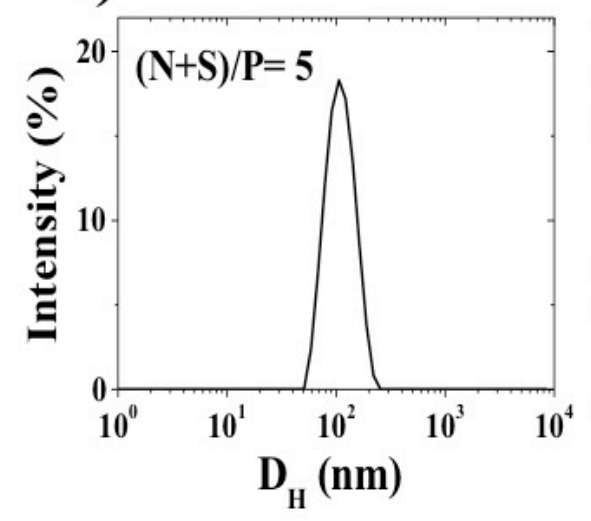

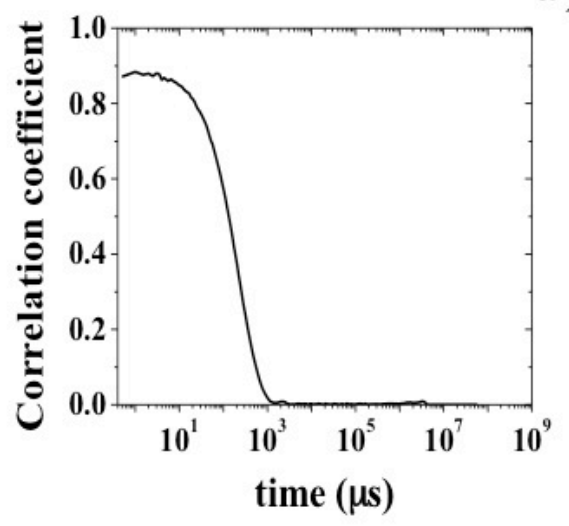

b)

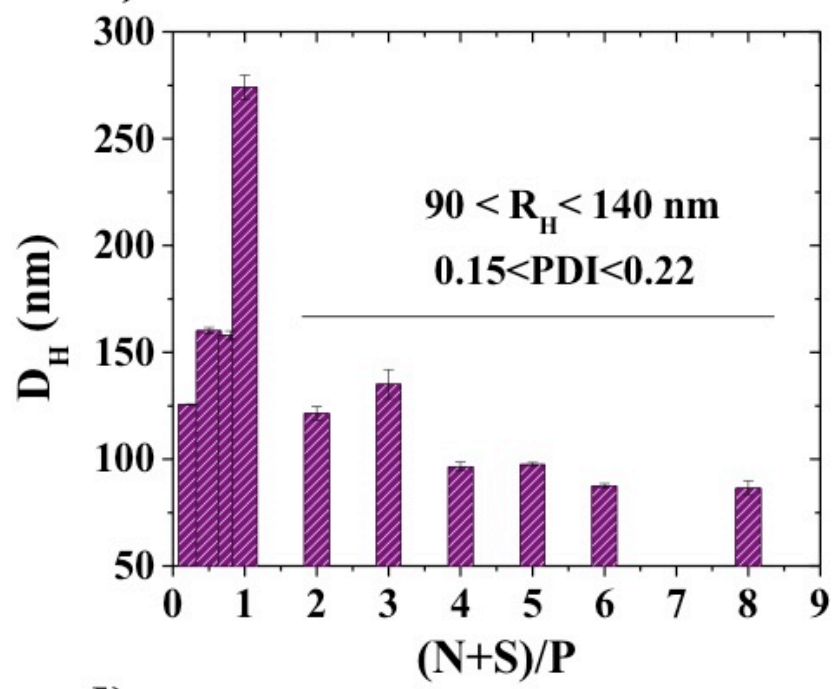

d)

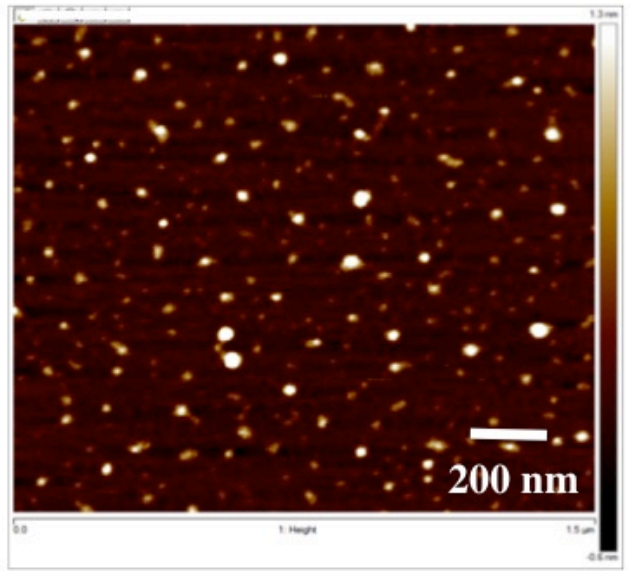


Figure 5

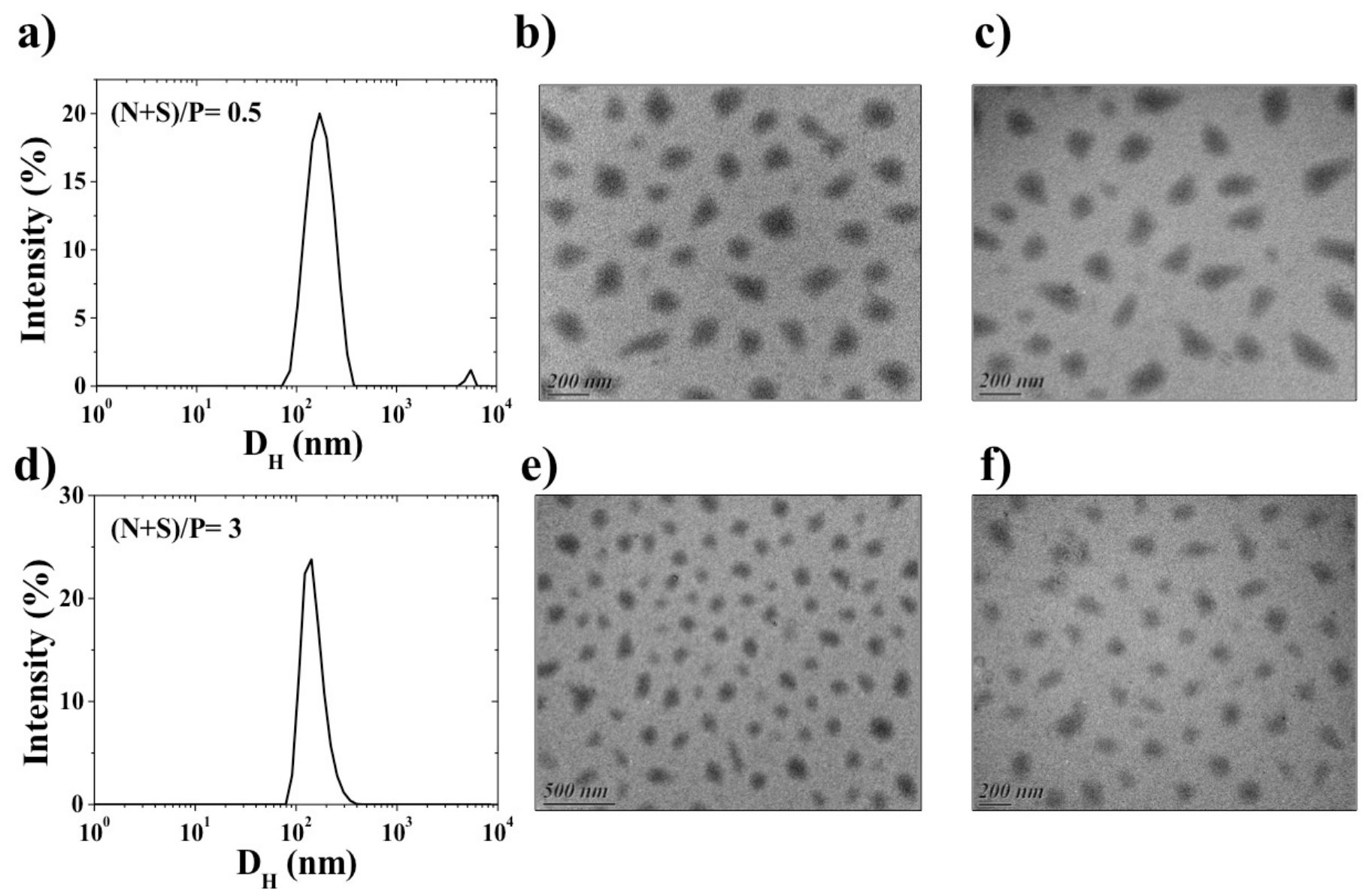


Figure 6

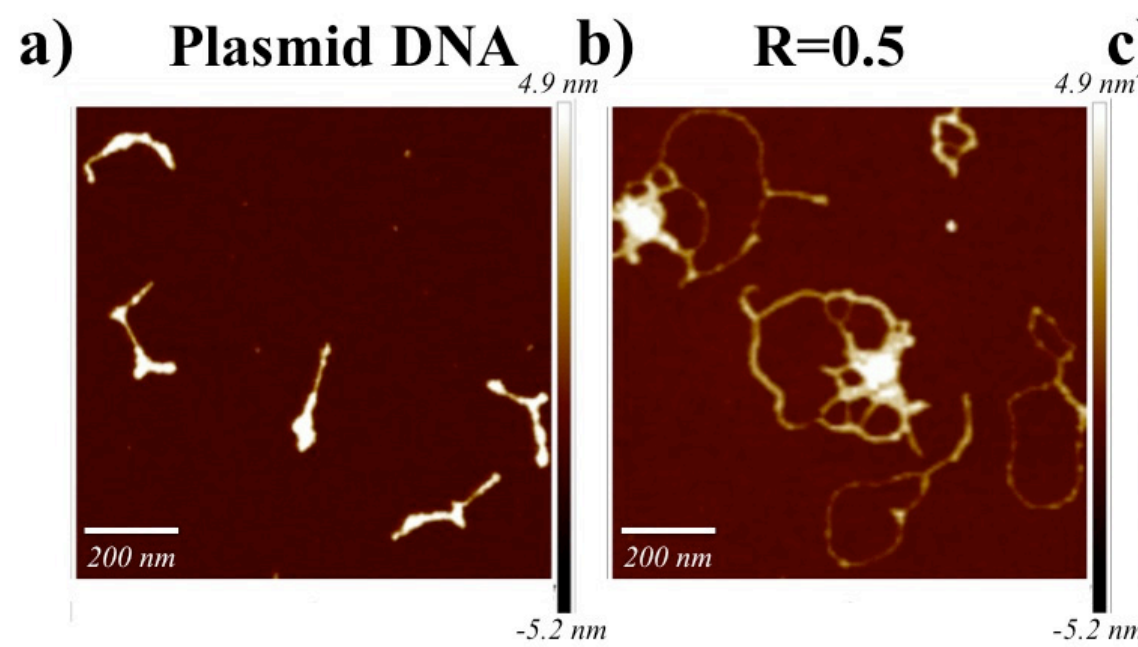

c) $\quad \mathrm{R}=\mathbf{0 . 8}$

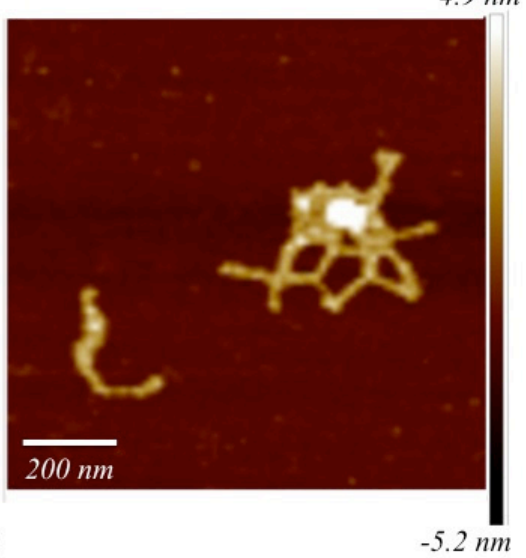

d)

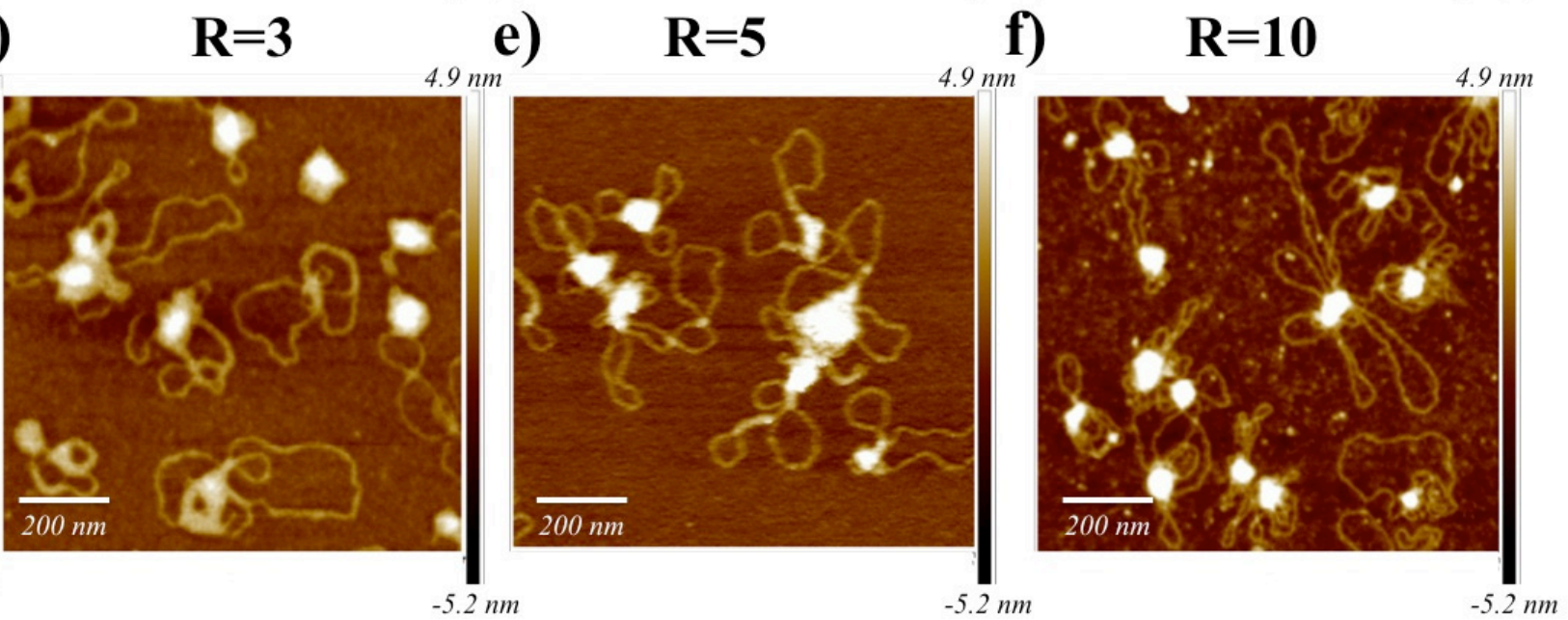


Figure 7
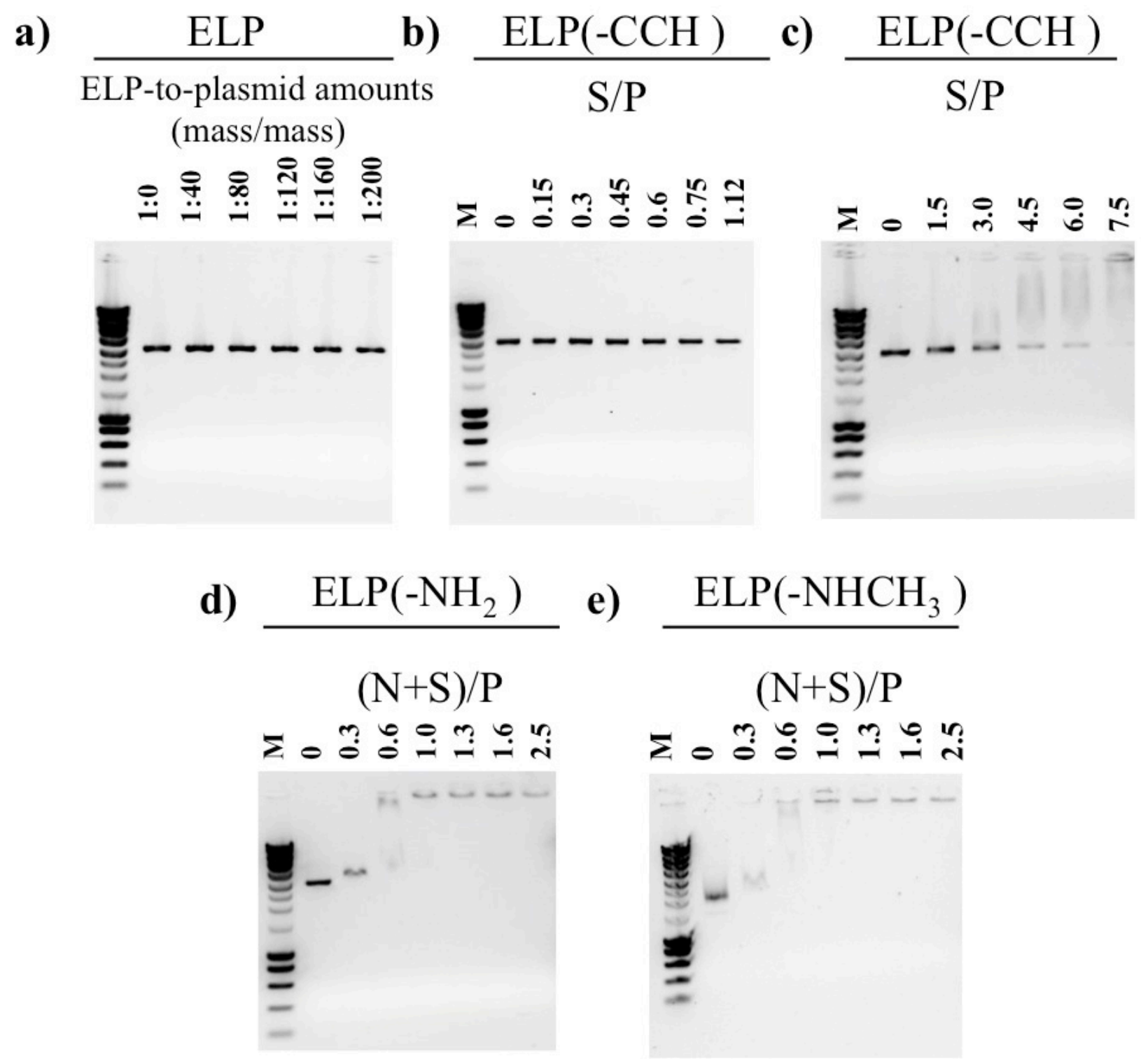


\section{Figure 8}

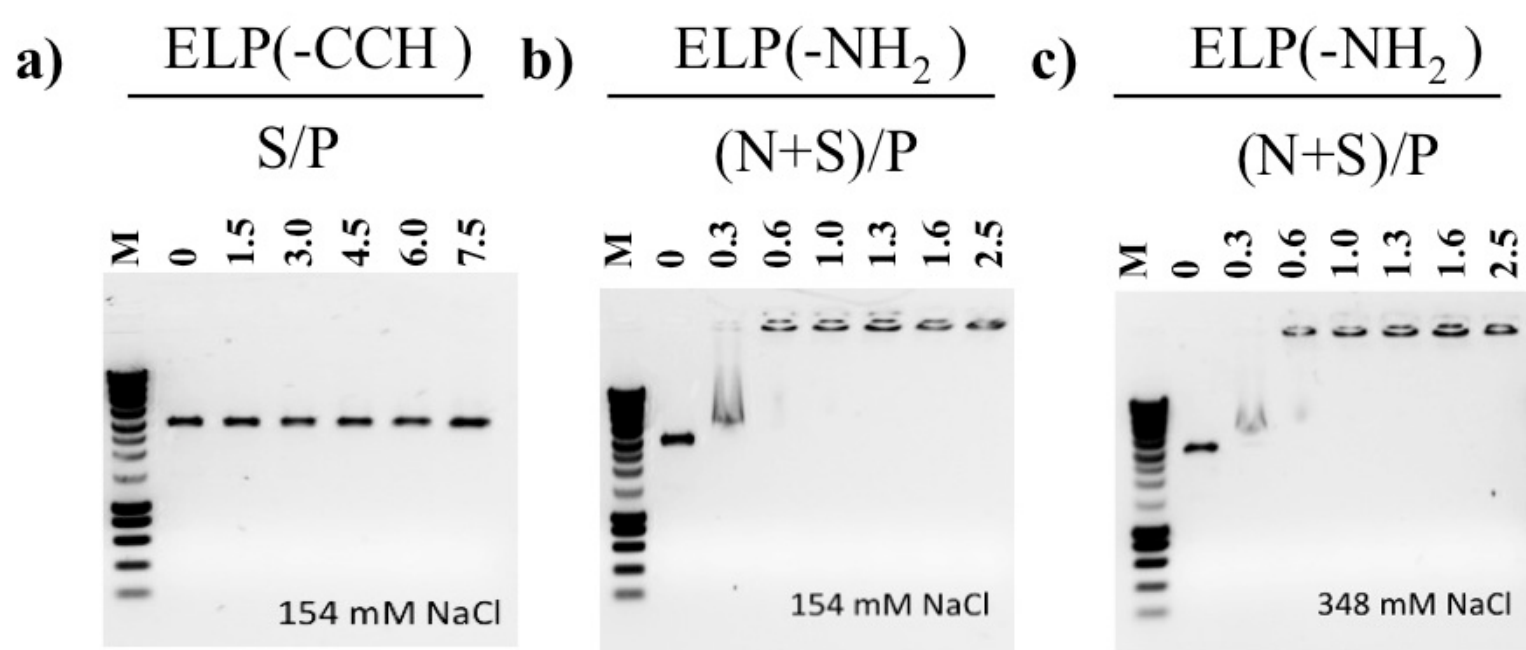

d)

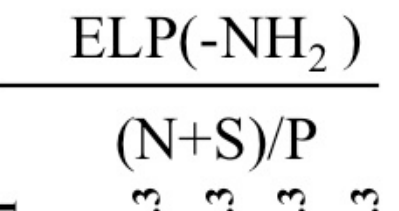

$\Sigma 0 \stackrel{?}{9} ?$

$\mathrm{NaCl}(\mathrm{M})$

- $\stackrel{\vec{\theta}}{\ddot{\theta}} \tilde{\theta}$

- - - - e) $\operatorname{ELP}\left(-\mathrm{NH}_{2}\right)$

$(\mathrm{N}+\mathrm{S}) / \mathrm{P}$

$\Sigma 0 \stackrel{?}{\longrightarrow} \stackrel{?}{\longrightarrow}$

SDS (\%)

- ت̆
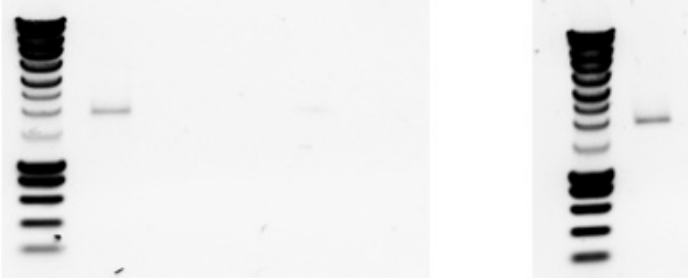
Table 1. Characteristics of ELP derivatives. Molecular weight and \% of dimerization determined by SDS-PAGE analysis and SEC measurements (using $d n / d c$ ), isoelectric point (IP) determined by potentiometric titrations and $\zeta$-potential measurements and $T_{t}$ determined by absorbance as a function of temperature measurements.

\begin{tabular}{|c|c|c|c|c|c|c|c|c|}
\hline \multirow[b]{2}{*}{$\begin{array}{c}\text { ELP } \\
\text { derivative }\end{array}$} & \multirow[b]{2}{*}{$\begin{array}{l}\text { Theoretical } \\
\text { MW (g/mol) }\end{array}$} & \multirow{2}{*}{$\begin{array}{c}{ }^{1} \text { H NMR } \\
\text { MW } \\
(\mathrm{g} / \mathrm{mol})^{\mathrm{a}}\end{array}$} & \multirow{2}{*}{$\begin{array}{c}\text { SDS-PAGE } \\
\text { Apparent MW } \\
(\text { Da })^{b} \\
\end{array}$} & \multicolumn{2}{|c|}{ SEC } & \multirow[b]{2}{*}{ IP } & \multicolumn{2}{|c|}{$\mathbf{T}_{t}\left({ }^{\circ} \mathrm{C}\right)$} \\
\hline & & & & $d n / d c^{c}$ & $\begin{array}{c}\text { MW } \\
(\mathrm{g} / \mathrm{mol})^{\mathrm{d}}\end{array}$ & & $100 \mu \mathrm{M}$ & $1 \mathrm{mM}$ \\
\hline ELP & 17035.4 & 17035.4 & 19500 & 0.139 & 17370 & 5.65 & 35 & 28 \\
\hline ELP(-CCH) & 18279.9 & 18279.1 & 21200 & 0.136 & 18370 & 10.74 & 48 & 41 \\
\hline ELP(-NH $\left.{ }_{2}\right)$ & 19226.9 & 19226.1 & 23800 & 0.128 & 20040 & 10.14 & ND & ND \\
\hline $\mathrm{ELP}\left(-\mathrm{NHCH}_{3}\right)$ & 19381.2 & 19380.4 & 22500 & 0.128 & 21398 & 10.22 & ND & ND \\
\hline
\end{tabular}

${ }^{a}$ Molecular weights of ELP derivatives were estimated from ${ }^{1} \mathrm{H}$ NMR measurements taking the molecular of the initial ELP (confirmed by MS) to calibrate the spectrum [46]. For this purpose, the \% of functionalization was multiplied by 11 available methionines and by the molecular weight of the respective functional group grafted for each chemical post-modification (alkynes, primary and secondary amines), then added to the initial ELP molecular weight.

${ }^{b}$ Molecular weights of ELP derivatives were estimated by gel electrophoresis from the intensity of the band by using the Image Lab Software ${ }^{\circledR}$ in a Bio-Rad Gel Doc EZ Imager.

${ }^{c}$ Determined by size exclusion chromatography.

${ }^{d}$ Molecular weights of ELPs derivatives were determined from SEC measurements by using a multi-angle light scattering detector. The intensity of the resulting scattered light from relaxation of the molecule (collected by the detector) was measured as the Raleigh ratio $R_{\Theta}$, which is directly proportional to the molecular weight of the solute molecule scattering the light. dn/dc values were used to assess to this information 
Table 2. pUC19 plasmid/ELP(-NH2) complex characterization through TEM (average particle size) and Dynamic Light Scattering measurements (Hydrodynamic diameter, $D_{H}$, Scattered intensity, $I_{S C A}$ and PDI) for two different charge ratios, $(N+S) / P=0.5$ and 3.0. $C_{p U C 19}=0.005$ $\mathrm{g} / \mathrm{L}$ prepared in Tris $10 \mathrm{mM}$ buffer at a $\mathrm{pH}=7.4, C_{E L P(-\mathrm{NH} 2)}=0.2 \mathrm{~g} / \mathrm{L}$ prepared at $\mathrm{pH}=6.0$. pUC19 plasmid/ELP $\left(-\mathrm{NH}_{2}\right)$ complexes were prepared through the rapid one-shot mixing method (cationic ELPs to anionic DNA).

\begin{tabular}{|c|c|c|c|c|c|}
\hline \multirow{2}{*}{$(\mathbf{N}+\mathbf{S}) / \mathbf{P}$} & \multicolumn{3}{|c|}{ DLS } & \multirow{2}{*}{$\begin{array}{c}\zeta \text {-potential } \\
(\mathrm{mV})\end{array}$} & \multirow{2}{*}{$\begin{array}{c}\text { Particle diameter } \\
(\mathrm{nm})\end{array}$} \\
\hline & $\mathrm{D}_{\mathrm{H}}(\mathrm{nm})$ & I $_{\text {SCA }}$ (a.u.) & PDI & & \\
\hline 0.5 & $168 \pm 10$ & $33 \pm 0.7$ & 0.160 & $-15 \pm 5$ & $145 \pm 22$ \\
\hline 3.0 & $135 \pm 5$ & $623 \pm 3$ & 0.005 & +15 & $115 \pm 16$ \\
\hline
\end{tabular}

${ }^{a}$ Determined from transmission electron micrographs. 


\section{Supporting information}

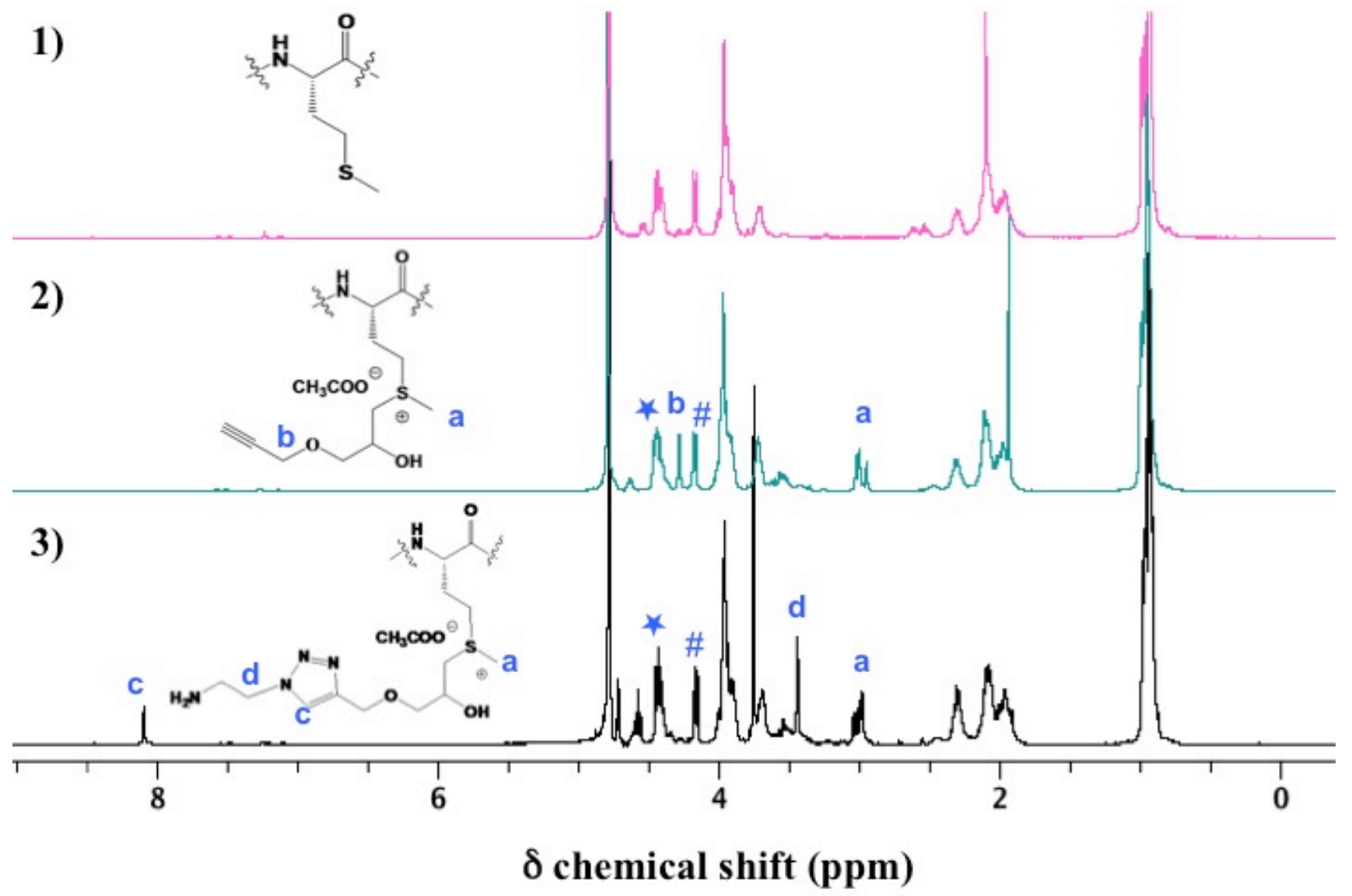

Figure S1. Superimposed ${ }^{1} \mathrm{H}$ NMR spectra of 1) ELP, 2) ELP(-CCH) and 3) ELP(- $\left.\mathrm{NH}_{2}\right)$ in $\mathrm{D}_{2} \mathrm{O}$ at $298 \mathrm{~K}$. Resonance \# corresponds to $\mathrm{Val} \alpha \mathrm{CH}$ of the guest residue in VPGVG repeat units, and resonance $\star$ corresponds to $\mathrm{Val} \alpha \mathrm{CH}$ and Pro $\alpha \mathrm{CH}$ of VPGXG repeats. 


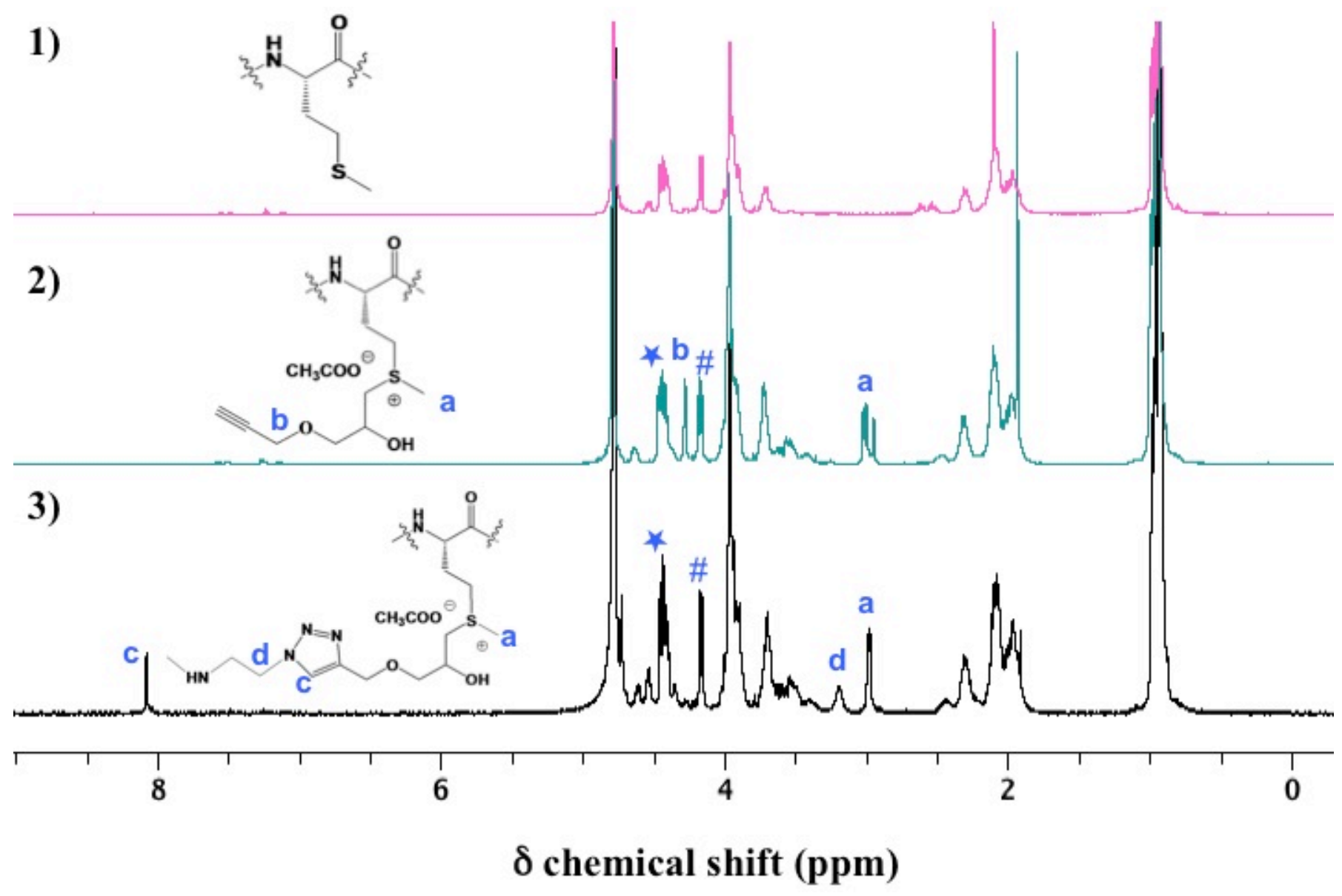

Figure S2. Superimposed ${ }^{1} \mathrm{H}$ NMR spectra of 1) ELP, 2) ELP(-CCH) and 3) ELP(- $\left.\mathrm{NHCH}_{3}\right)$ in $\mathrm{D}_{2} \mathrm{O}$ at $298 \mathrm{~K}$. Resonance \# corresponds to $\mathrm{Val} \alpha \mathrm{CH}$ of the guest residue in VPGVG repeat units, and resonance $\star$ corresponds to $\mathrm{Val} \alpha \mathrm{CH}$ and Pro $\alpha \mathrm{CH}$ of $\mathrm{VPGXG}$ repeats. 


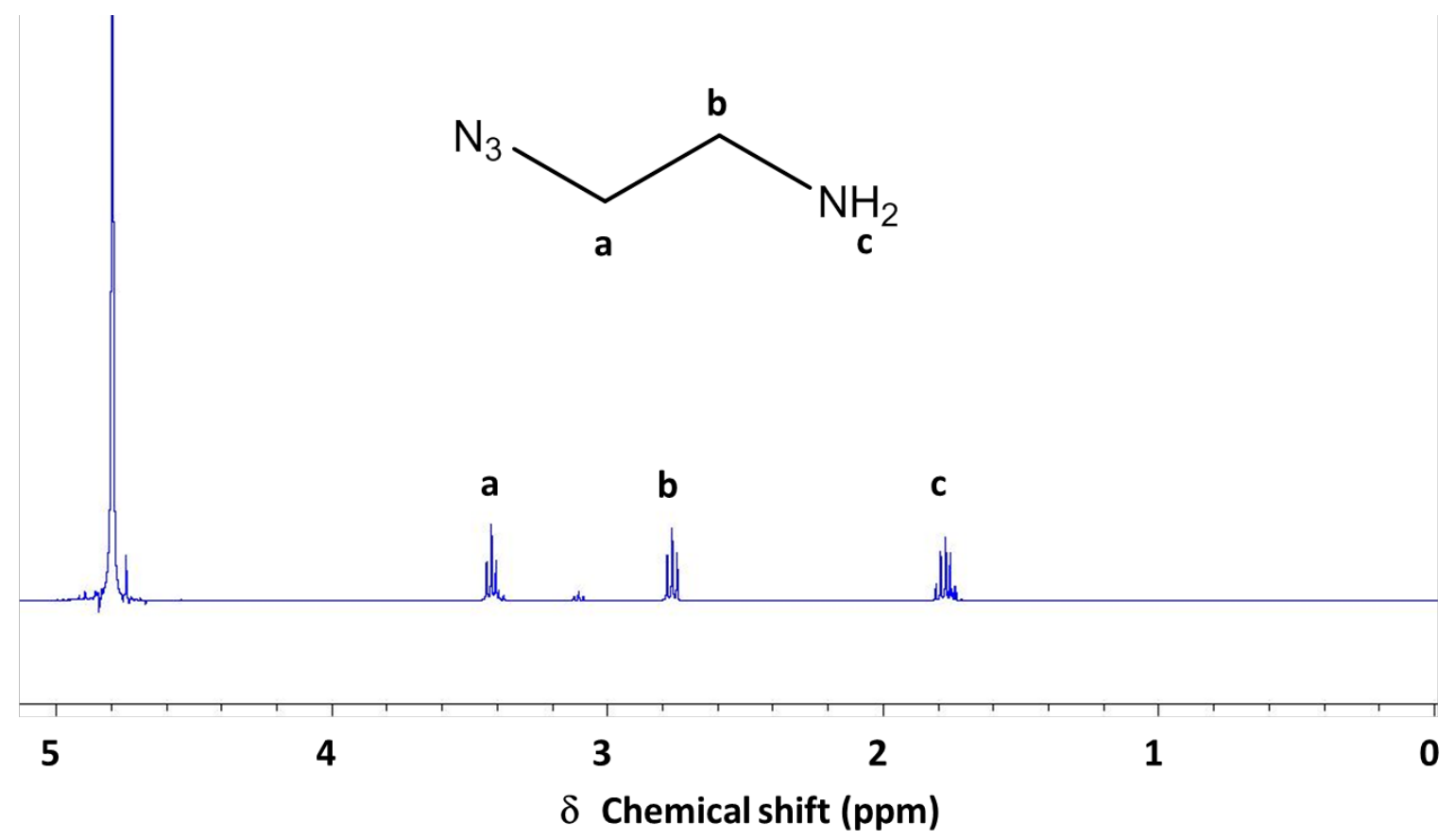

Figure S3. ${ }^{1} \mathrm{H}$ NMR spectrum of 2-aminoethylazide in $\mathrm{D}_{2} \mathrm{O}$ at $278 \mathrm{~K}$.

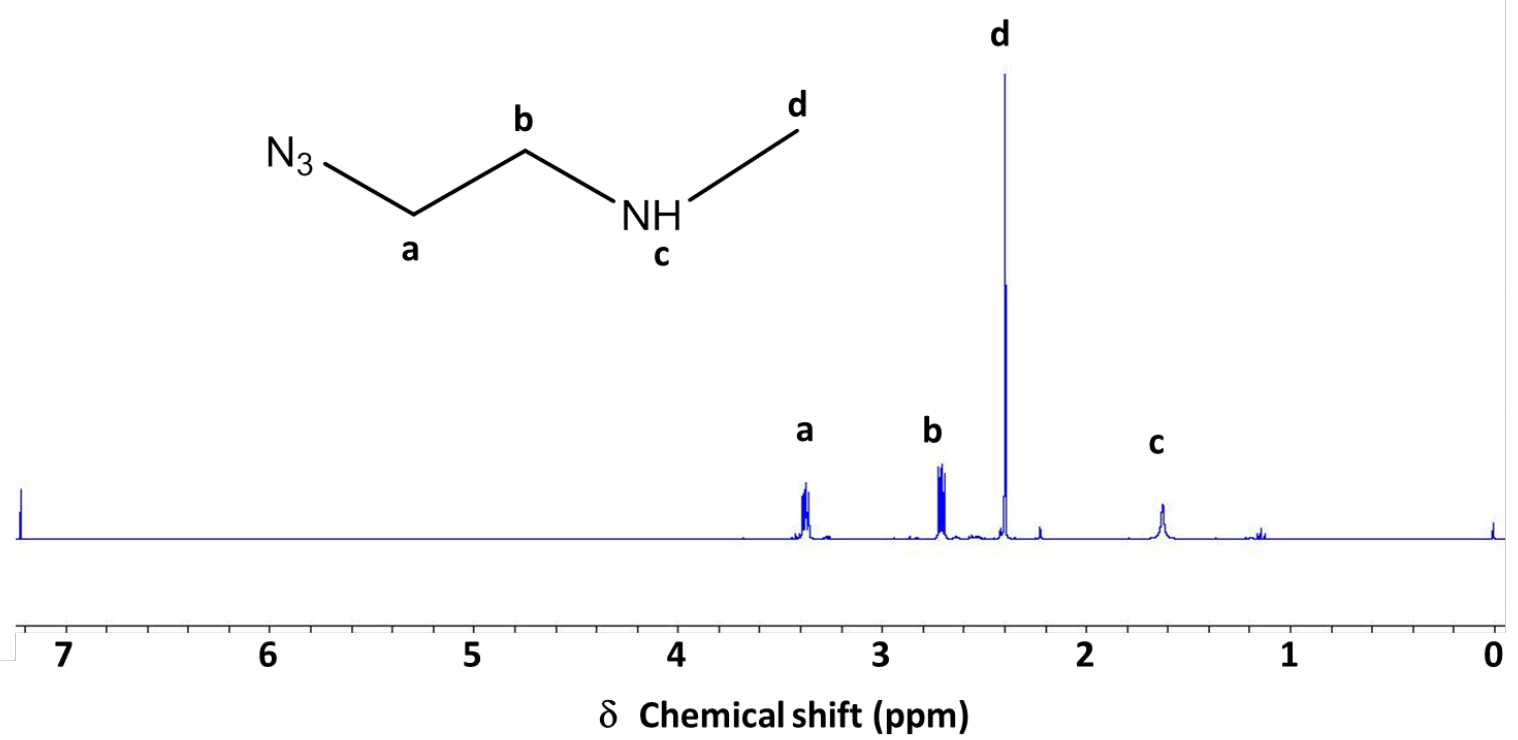

Figure S4. ${ }^{1} \mathrm{H}$ NMR spectrum of (2-azidoethyl)methylamine in $\mathrm{CDCl}_{3}$ at $278 \mathrm{~K}$. 
a)

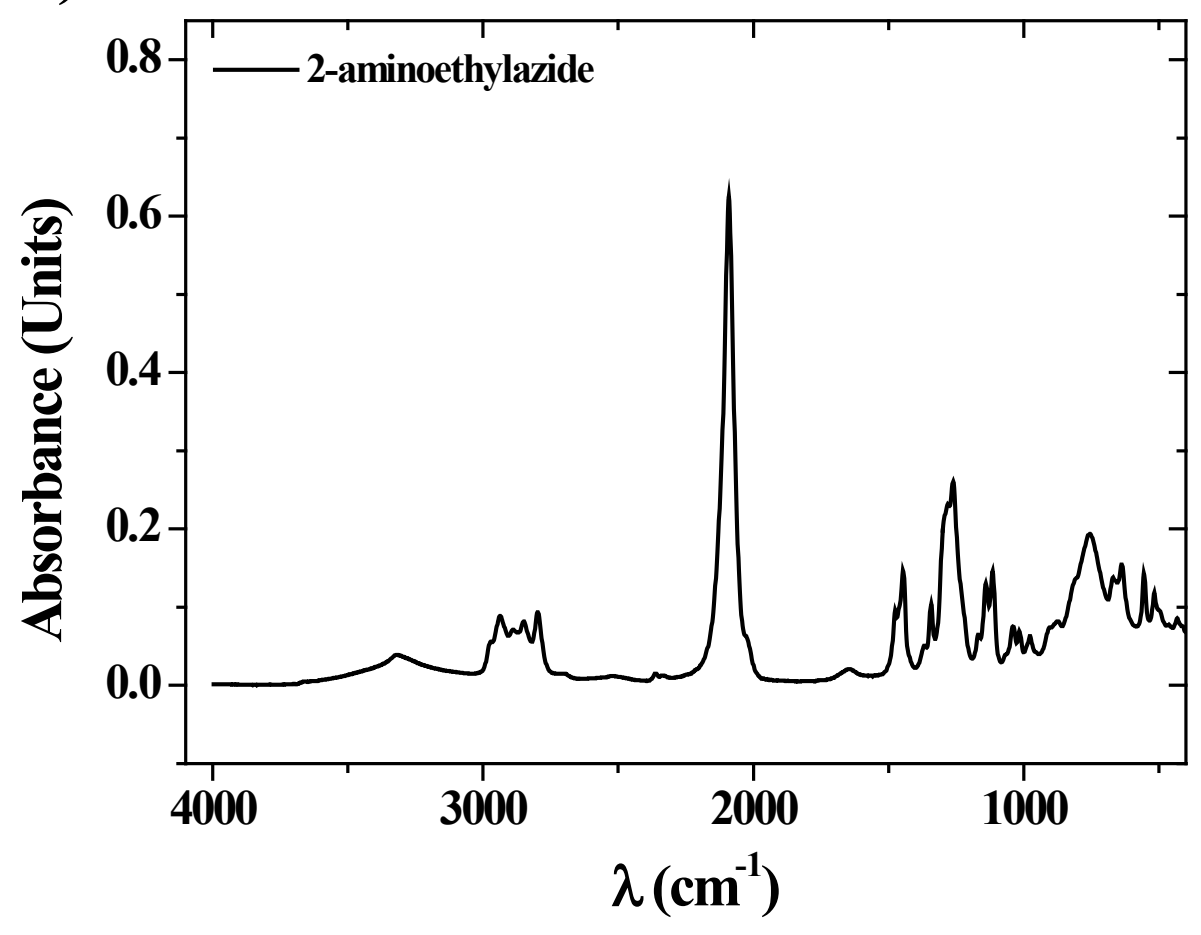

b)

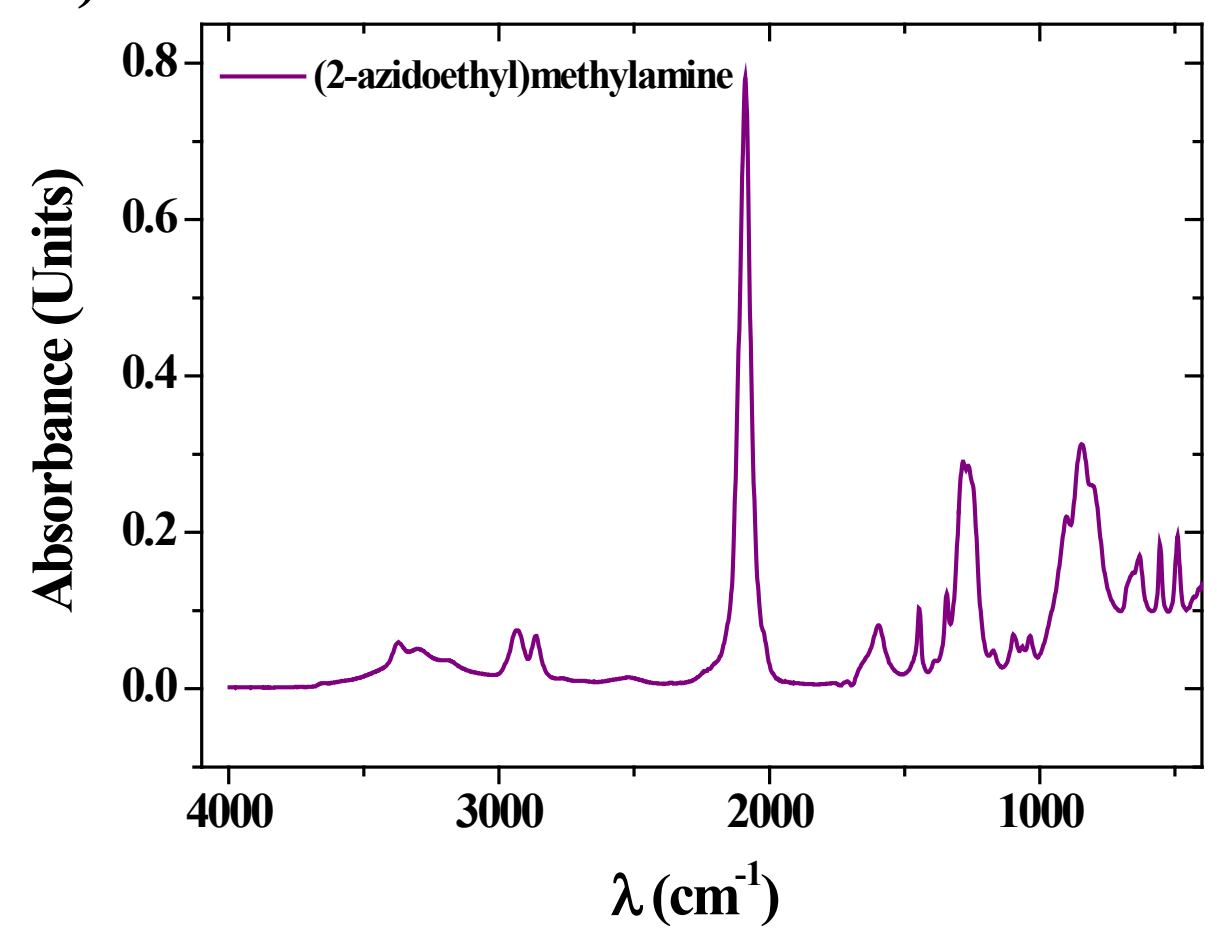

Figure S5. Infra-red spectra of a) 2-aminoethylazide and b) (2-azidoethyl)methylamine after reaction with sodium azide. 


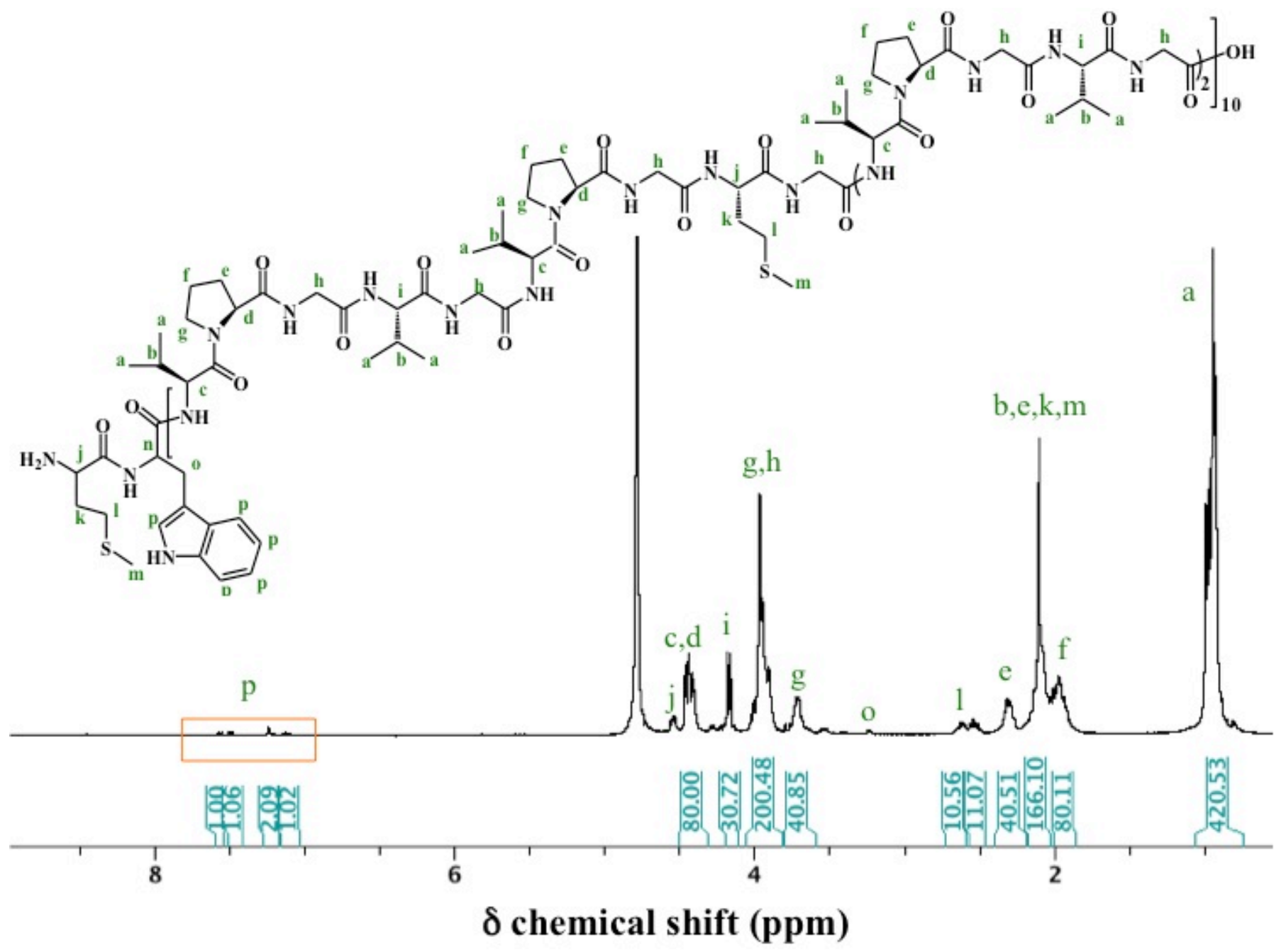

Figure S6. ${ }^{1} \mathrm{H}-\mathrm{NMR}$ spectra of ELP in $\mathrm{D}_{2} \mathrm{O}$ at $298 \mathrm{~K}$. 


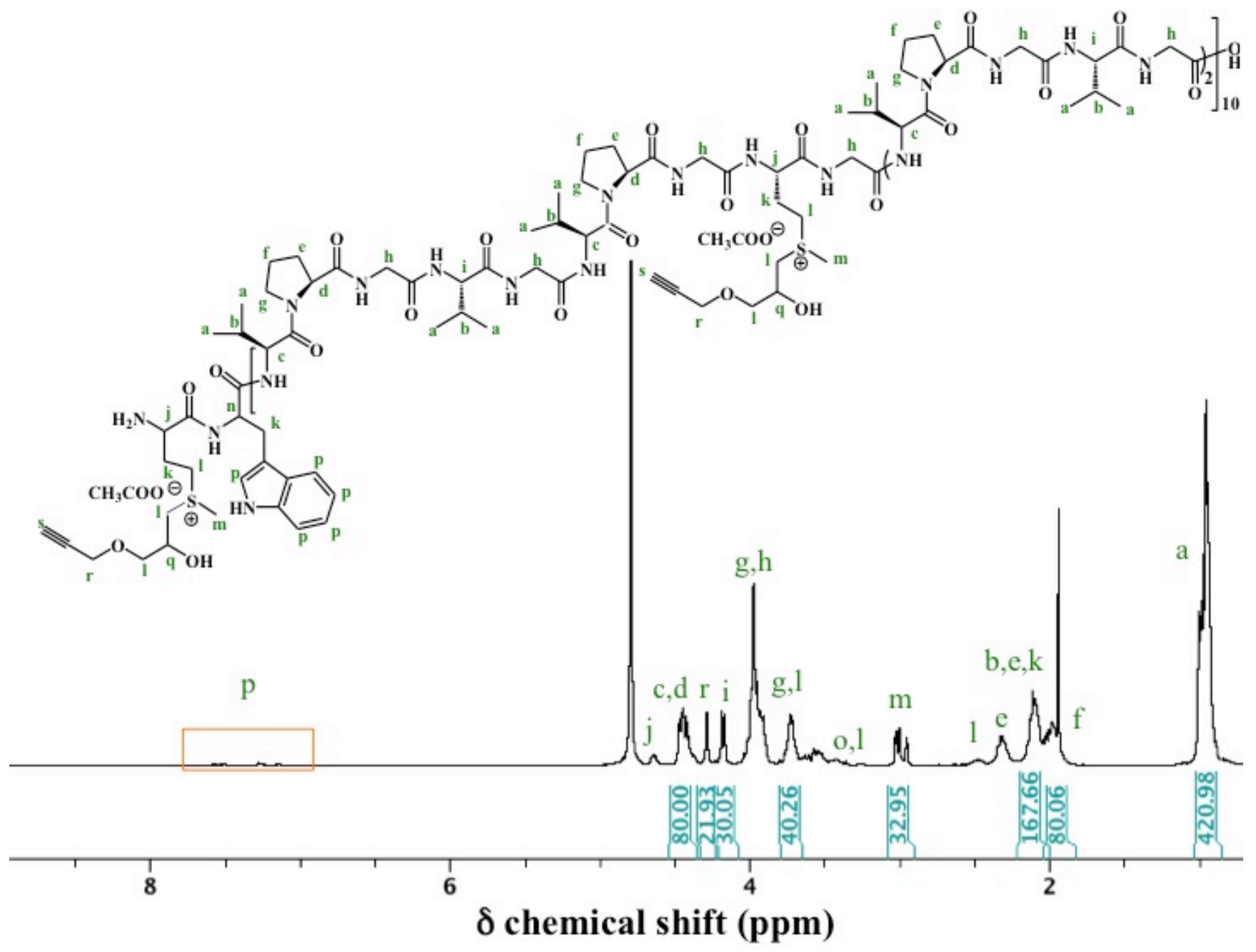

Figure S7. ${ }^{1} \mathrm{H}-\mathrm{NMR}$ spectrum of ELP(-CCH) in $\mathrm{D}_{2} \mathrm{O}$ at $298 \mathrm{~K}$. 


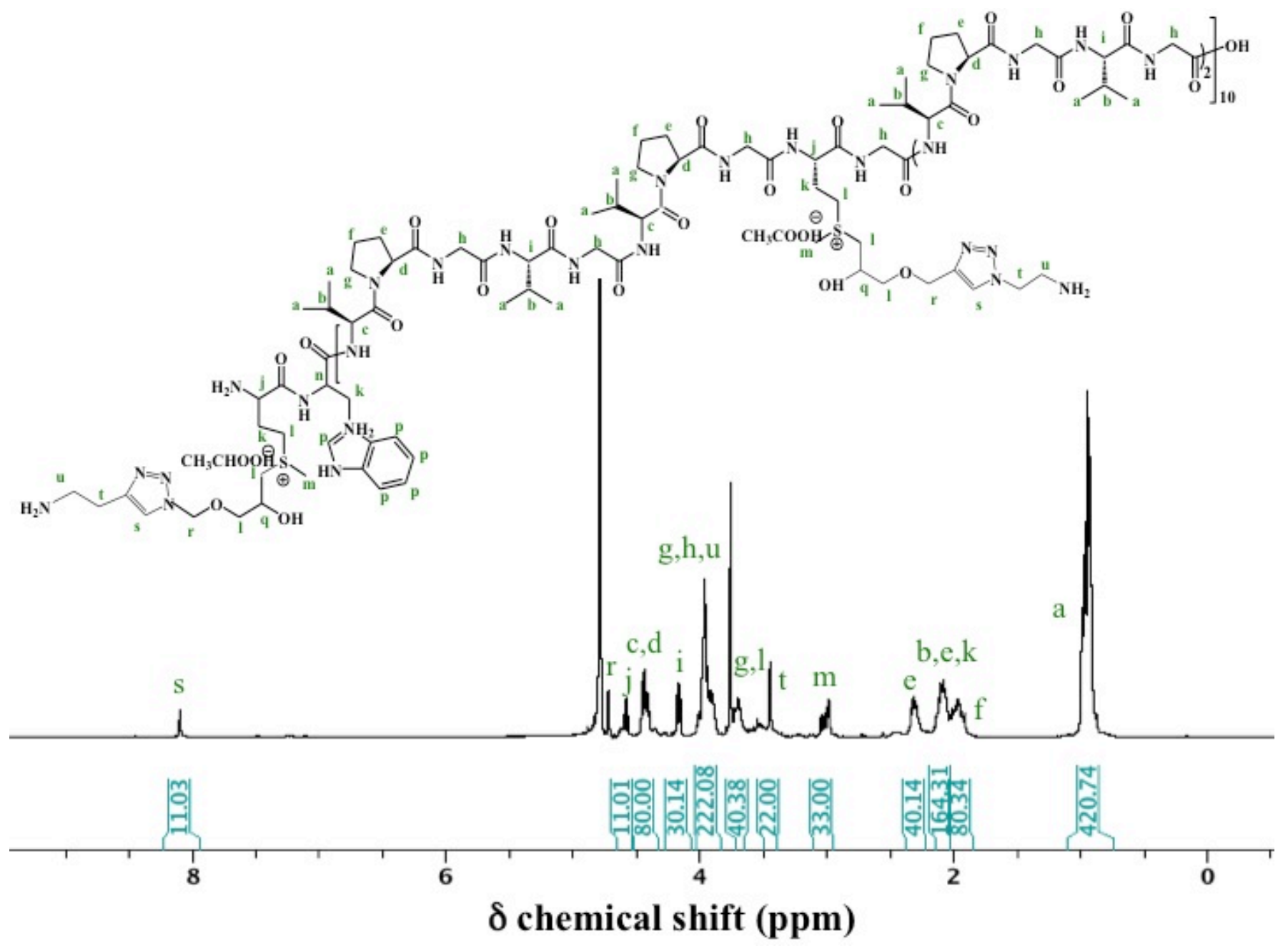

Figure S8. ${ }^{1} \mathrm{H}-\mathrm{NMR}$ spectrum of $\operatorname{ELP}\left(-\mathrm{NH}_{2}\right)$ in $\mathrm{D}_{2} \mathrm{O}$ at $298 \mathrm{~K}$. 


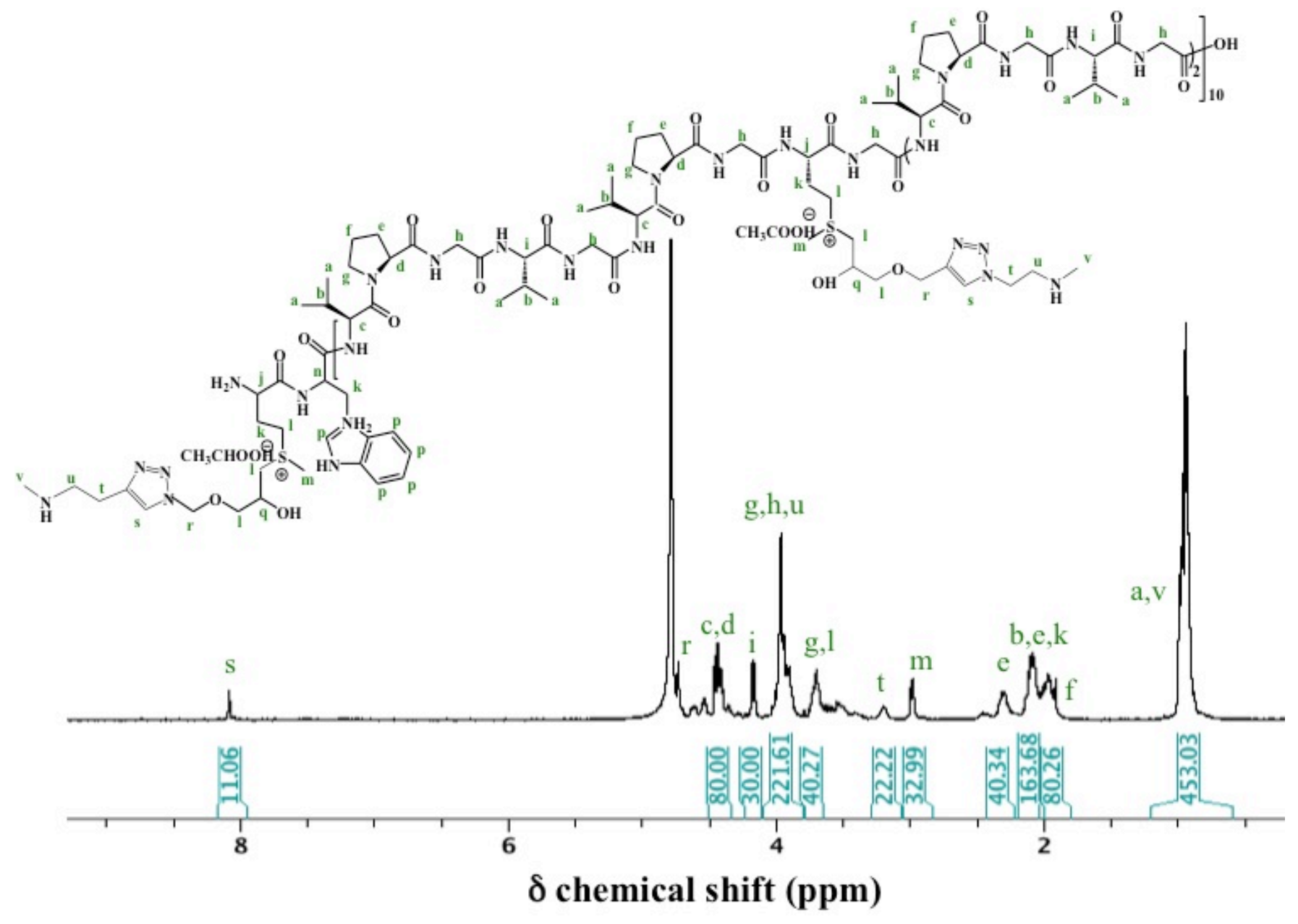

Figure S9. ${ }^{1} \mathrm{H}-\mathrm{NMR}$ spectrum of ELP(-NHCH 3$)$ in $\mathrm{D}_{2} \mathrm{O}$ at $298 \mathrm{~K}$. 


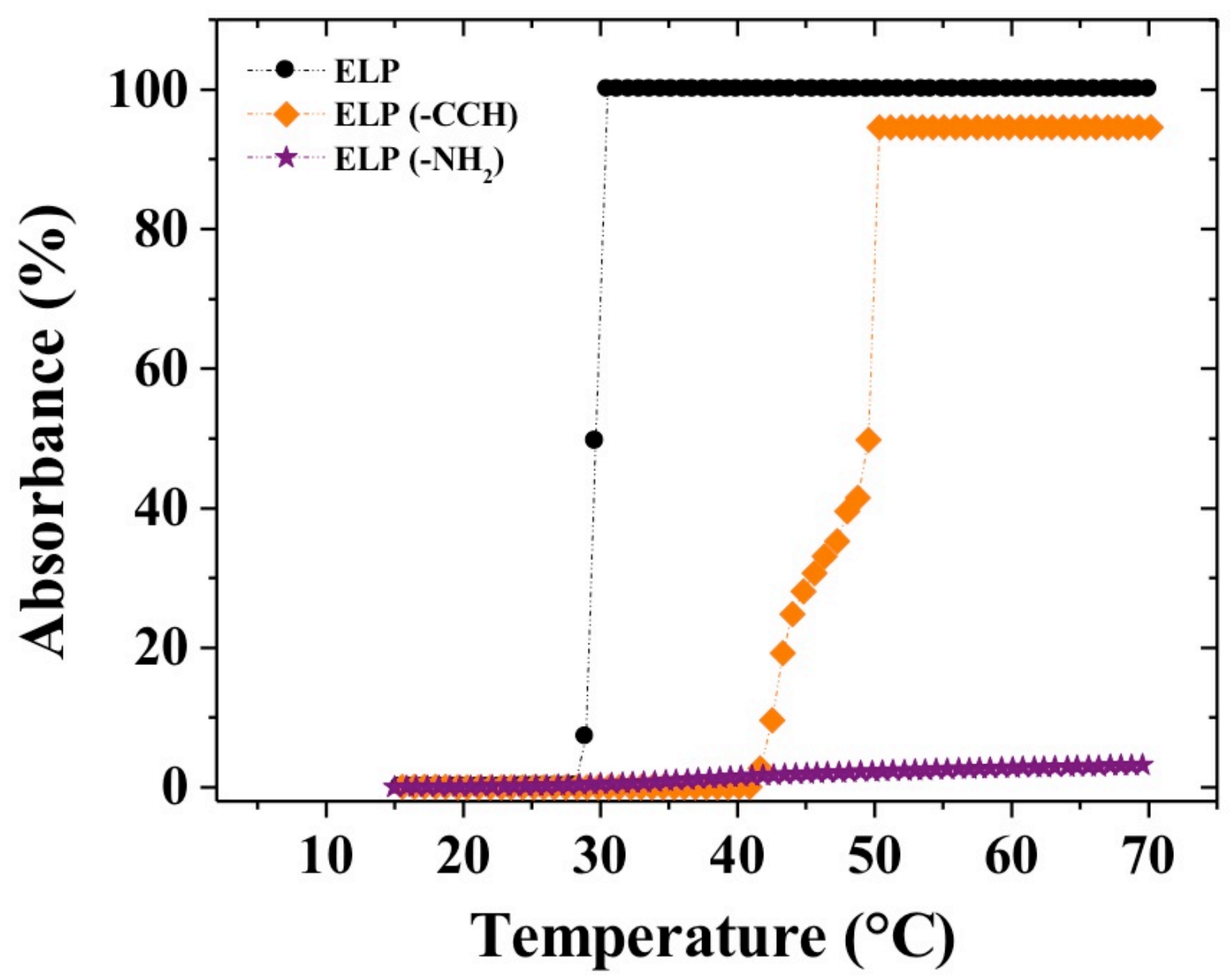

Figure S10. Absorbance (\%) at $600 \mathrm{~nm}$ of $1 \mathrm{mM}$ solutions of ELP, ELP(-CCH) and ELP($\left.\mathrm{NH}_{2}\right)$ in Tris buffer $(10 \mathrm{mM})$ as a function of temperature. 


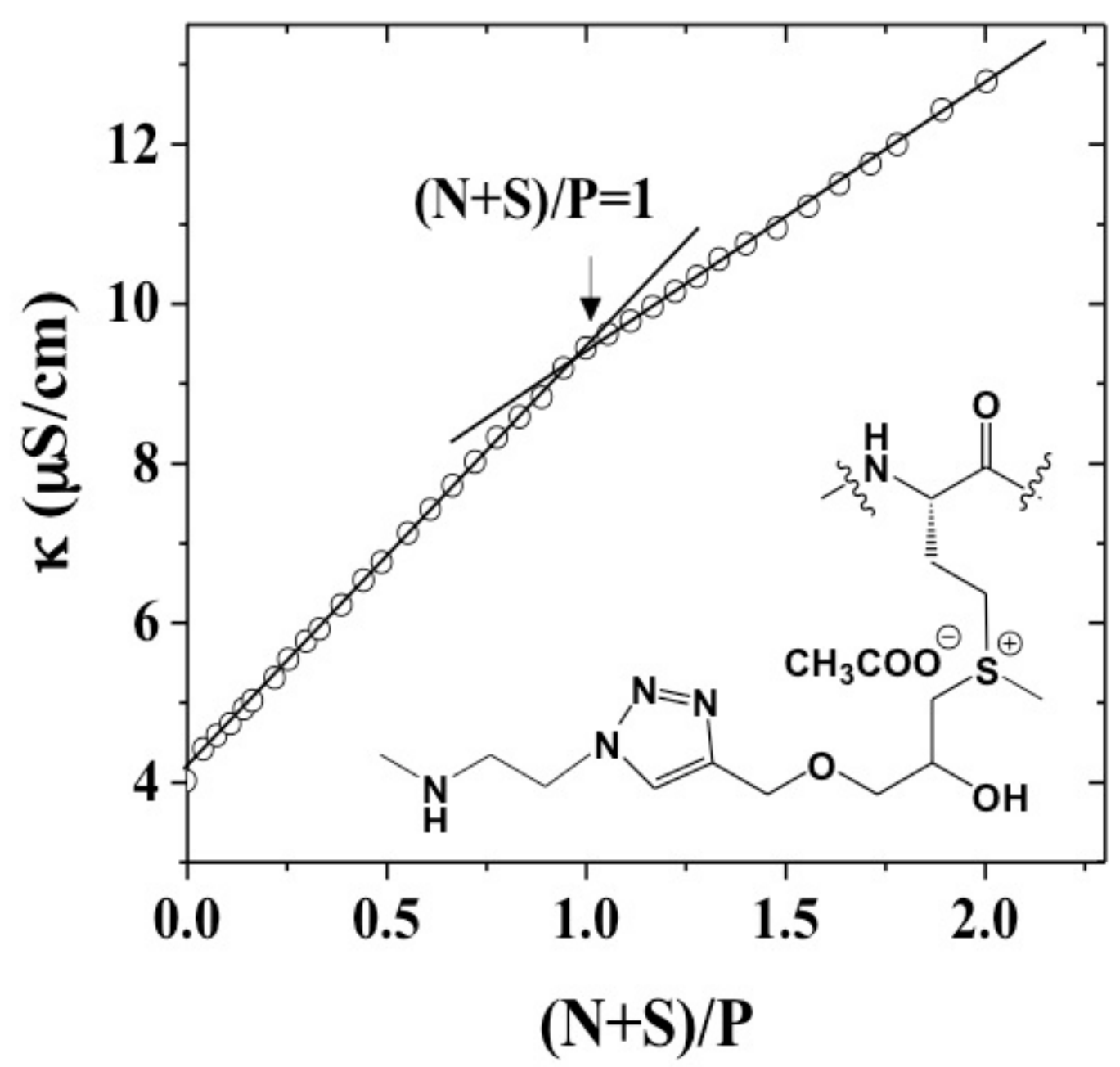

Figure S11. Electrical conductivity $(\kappa)$ dependence on the ratio $(\mathrm{N}+\mathrm{S}) / \mathrm{P}$ during $\mathrm{CT}$ DNA/ELP(-NHCH 3 ) complex formation. Temperature measurement: $25^{\circ} \mathrm{C} . \mathrm{C}_{\mathrm{DNA}}=0.0 .1$ $\mathrm{g} / \mathrm{L}$ in water at $\mathrm{pH}=6.5, \mathrm{C}_{\mathrm{ELP}(-\mathrm{CCH})}=2 \mathrm{~g} / \mathrm{L}$ and $\mathrm{C}_{(-\mathrm{NHCH} 3)}=2 \mathrm{~g} / \mathrm{L}$, both prepared at $\mathrm{pH}=6.0$. 


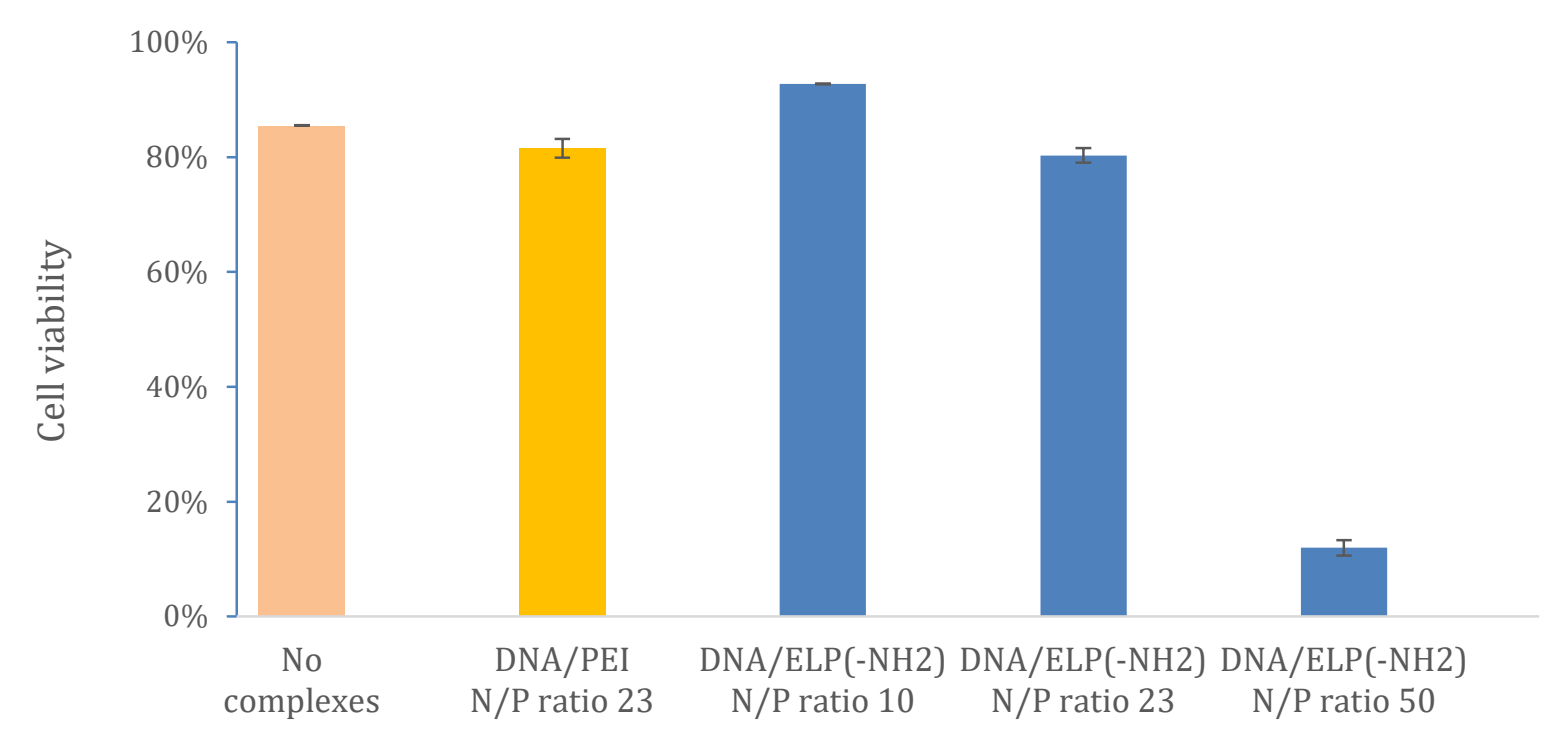

Figure S12. Cell viability (\%) of HEK 293 cells with DNA/ELP(-NHCH 3$)$ complexes having different $(\mathrm{N}+\mathrm{S}) / \mathrm{P}$ ratios. Cell viability of cells without complexes and cells with DNA/PEI complexes $(\mathrm{R}=23)$ was also tested.

\section{Preliminary in vitro testing on HEK 293 cells viability}

HEK293 suspension cells (FreeStyle 293-F Cells, Ref. R790-07, Invitrogen) were cultivated in 6 well plates (Thermo Fischer Scientific, Nunc Ref. 150239), at $37^{\circ} \mathrm{C}, 100$ rpm, 8\% $\mathrm{CO}_{2}$, in serum free medium (FreeStyle 293 expression medium, ref. 12338018, ThermoFischer Scientific) with a $2 \mathrm{~mL}$ culture volume. Cells were incubated with (i) DNA/ELP $\left(-\mathrm{NH}_{2}\right)$ complexes prepared at three charge ratios, $(\mathrm{N}+\mathrm{S}) / \mathrm{P}$ of 10, 23 and 50, (ii) with DNA/PEI complexes prepared at a N/P ratio of 23 as described in the literature [1], and (iii) without any complexes as control. In-house ADV-1 control plasmid (4.7 kb) was used as DNA source. Solutions of $\operatorname{ELP}\left(-\mathrm{NH}_{2}\right)$ derivatives were prepared at $2 \mathrm{~g} / \mathrm{L}$ in DI water containing a stoichiometric amount of $\mathrm{HCl} 0.1 \mathrm{~N}$ on the basis of $\mathrm{NH}_{2}$ content (final pH around 6.0). Polyethylenimine (PEI 25 kDa, Ref. 23966 lot 661897, Polysciences) was dissolved in distilled water at $1 \mathrm{mg} / \mathrm{mL}$ and adjusted to $\mathrm{pH} 7$.

Briefly, cells were passaged every 2-3 day in serum free medium. At day of complexes addition cells were passaged at 1 million cell $/ \mathrm{ml}$ with viability over $90 \%$. DNA and 
polymers were prior conditioned in PBS and complexes were prepared at ratios mentioned above and added to cells at $1 \mu \mathrm{g}$ DNA per million cells with an addition of $10 \% \mathrm{v} / \mathrm{v}$. After $24 \mathrm{~h}$ incubation cell suspensions were injected on a cytometer (Accury C6, BD Biosciences) for cell distribution and viability analysis. Corresponding cell viability is reported on supplementary figure.

(1) M. de Los Milagros Bassani Molinas, C. Beer, F. Hesse, M. Wirth, R. Wagner, Optimizing the transient transfection process of HEK-293 suspension cells for protein production by nucleotide ratio monitoring, Cytotechnology 66 (2014) 493-514. 